\title{
OS LIMITES DO PODER DISCRICIONÁRIO DA ADMINISTRAÇÃO PÚBLICA NA IMPOSIÇÃO DE SANÇÕES ADMINISTRATIVAS:
ANÁLISE DAS SANÇÕES APLICÁVEIS PELO BANCO CENTRAL DO BRASIL

\author{
Dissertação de Mestrado \\ Orientadora: Prof. Dra. Maria Sylvia Zanella Di Pietro
}

FACULDADE DE DIREITO - UNIVERSIDADE DE SÃO PAULO SÃO PAULO 


\section{UNIVERSIDADE DE SÃO PAULO}

FACULDADE DE DIREITO

\section{OS LIMITES DO PODER DISCRICIONÁRIO DA ADMINISTRAÇÃO PÚBLICA NA IMPOSIÇÃO DE SANÇÕES ADMINISTRATIVAS: ANÁLISE DAS SANÇÕES APLICÁVEIS PELO BANCO CENTRAL DO BRASIL}

Dissertação apresentada à Banca Examinadora da Faculdade de Direito da Universidade de São Paulo, como exigência para obtenção do título de Mestre em Direito, sob a orientação da Professora Doutora Maria Sylvia Zanella Di Pietro.

\section{SÃO PAULO}




\title{
FOLHA DE APROVAÇÃO
}

\author{
Eduardo Tognetti
}

Dissertação apresentada à Faculdade de Direito da Universidade de São Paulo para obtenção do título de Mestre em Direito Área de Concentração: Direito do Estado

Aprovado em

Banca Examinadora

Professor Dr.:

Instituição:

Assinatura:

Professor Dr.:

Instituição:

Assinatura:

Professor Dr.:

Instituição:

Assinatura: 
A minha mãe Márcia, meu pai Antonio Carlos e meu padrasto Maurício, por terem iniciado as páginas de minha história.

\begin{abstract}
A Silvania, Rachel e Deborah pelo amor incondicional que recebo de vocês e pelas experiências compartilhadas a cada dia que me permitem atualizar, ampliar e revisar minha história, para que eu possa ser cada dia melhor e mais feliz.
\end{abstract}




\section{AGRADECIMENTOS}

Este é um projeto de vários anos com a participação de muitas pessoas que apoiaram, incentivaram e ajudaram meu desenvolvimento acadêmico. Todas merecem ser lembradas nestas poucas linhas e certamente cometerei a injustiça de esquecer algumas delas. Saibam que fechada a edição, lembrarei e me punirei por tão imperdoável falha, mas tenham certeza de que me esforcei para lembrar de todos e peço que recebam meus agradecimentos.

Ao Prof. Ricardo Lobo Torres, grande incentivador dos meus estudos e que motivou muitas das reflexões que estão aqui registradas.

Ao conjunto de advogados do Banco do Brasil, aos quais agradeço na pessoa do diretor jurídico Antonio Pedro da Silva Machado. Espero que meu amadurecimento acadêmico possa reverter em soluções para os nossos desafios profissionais.

A meus colegas da Ajure São Paulo que, inconformados com os problemas de arbitrariedade do poder público, me forneceram subsídios e discussão de alto nível para que este trabalho fosse possível. Em especial, Vito Antonio Bocuzzi, José Augusto Moreira de Carvalho, Adriano de Andrade, Adriana Faraoni Freitas de Oliveira, Waldemar Fernandes Dias Filho, Denise Arent Miotto, Raquel Peres de Carvalho e Julio Sandoval.

Aos Professores com os quais convivi durante o curso, Floriano Peixoto de Azevedo Marques Neto, Tércio Sampaio Ferraz Júnior, Samuel Rodrigues Barbosa, Sílvio Luís Ferreira da Rocha, Manuel Fonseca Pires, Manoel Gonçalves Ferreira Filho, José Levi Mello do Amaral

Júnior, Fernando Dias Menezes de Almeida, Ada Pellegrini Grinover, Kazuo Watanabe, Susana Henriques da Costa, Ronaldo Porto Macedo Júnior, Jose Reinaldo de Lima Lopes, José Alexandre Tavares Guerreiro, Francisco Satiro Souza Júnior, que me proporcionaram importantes desafios intelectuais e incentivo para nunca deixar de pensar o direito.

E, sobretudo, agradeço à Professora Maria Sylvia Zanella Di Pietro, minha orientadora, pela inestimável oportunidade de desfrutar de seus conhecimentos, de sua experiência e de sua amizade. Não é necessário relatar o sentimento de gratidão, mesmo porque, qualquer tentativa não conseguiria apreender a totalidade de sua significação. Muito obrigado! 


\section{RESUMO}

Dissertação sobre o regime jurídico das infrações e sanções administrativas aplicadas pelo Conselho Monetário Nacional e o Banco Central do Brasil em conformidade com a legislação do Sistema Financeiro Nacional, especialmente a Lei 4.595/64. Apresenta o regime de distribuição da função legislativa a partir da Constituição Federal de 1998, o sistema jurídico das infrações e sanções administrativas e a diferenciação destas em relação a outros atos derivados do denominado poder de polícia. Em seguida, analisa a recepção pela Constituição Federal de 1988 do modelo normativo trazido pela Lei 4.595/64 e os limites da discricionariedade administrativa para aplicação de infrações e sanções administrativas à luz dos princípios da legalidade e da tipicidade apresentados pela doutrina.

Palavras-chave: sanção administrativa, princípio da legalidade, Banco Central do Brasil, princípio da tipicidade, discricionariedade 


\begin{abstract}
Dissertation on the legal regime of the administrative infractions and penalties imposed by the National Monetary Council and the Central Bank of Brazil in accordance with the rules of the Financial System, especially the Law 4.595/64. Displays the distribution scheme of the legislative function from the Federal Constitution of 1998, the system of legal administrative infractions and penalties and differentiation of these acts in relation to others derived from the so called police powers. It then goes through the reception by the Constitution of 1988 of the normative model issued by Law 4.595/64 and the limits of the administrative authorities discretion for application of administrative infractions and sanctions in the light of the principles of legality and typicality as presented by the doctrine.
\end{abstract}

Keywords: administrative penalties, principle of legality, Central Bank of Brazil, principle of typicality, discretion. 


\section{SUMÁRIO}

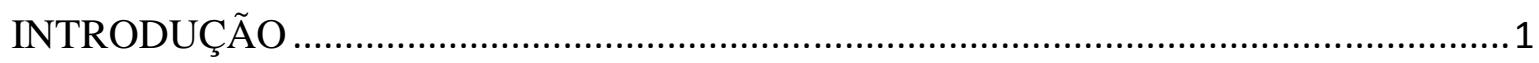

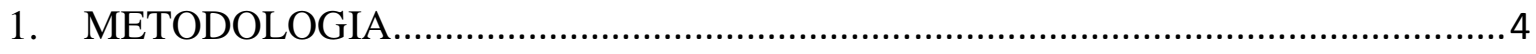

1.1 Dogmática jurídica como sistema de referência ............................................................ 4

1.2 Relação entre elementos integrantes da interpretação........................................................ 7

1.3 Separação entre interpretação e desenvolvimento do direito ........................................... 14

1.4 Direito visto como sistema constituído exclusivamente por normas válidas orientado a

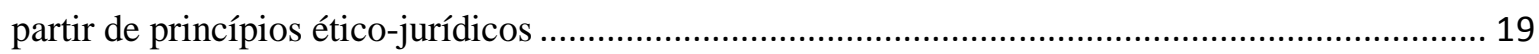

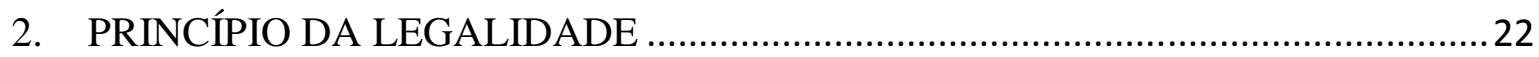

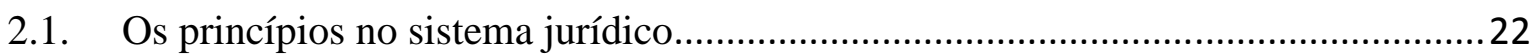

2.2. Fundamentos do princípio da legalidade ........................................................26

2.2.1. Separação de poderes com a finalidade de restringir o abuso de poder ....................29

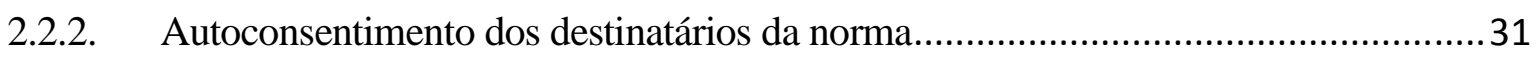

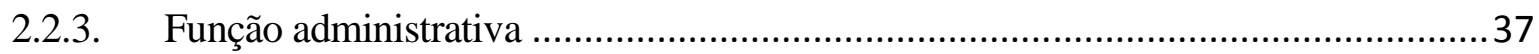

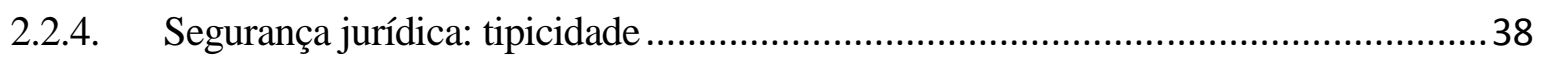

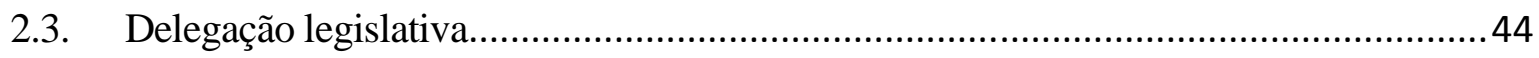

2.4. Princípio da legalidade na Constituição de 1988 ......................................................50

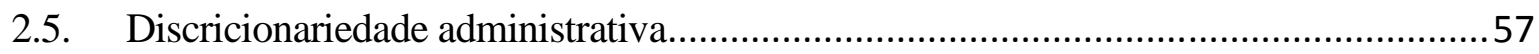

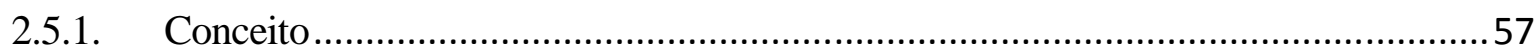

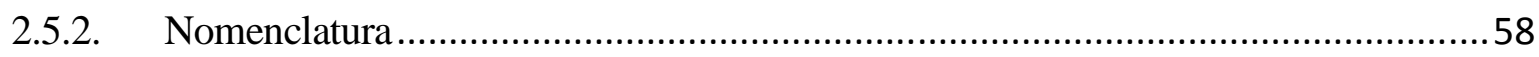

2.5.3. Discricionariedade e vinculação.....................................................................62

2.5.4. Discricionariedade e interpretação ...............................................................63

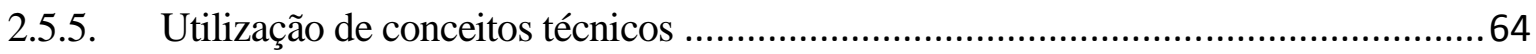

2.5.6. Conceitos jurídicos indeterminados e delegação legislativa...................................66

2.6. Modulação do princípio da legalidade: sujeição especial e geral ...............................67

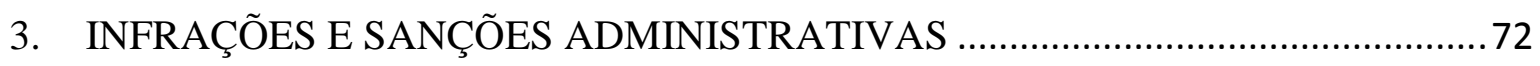

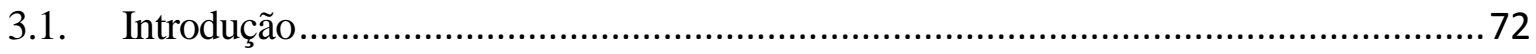

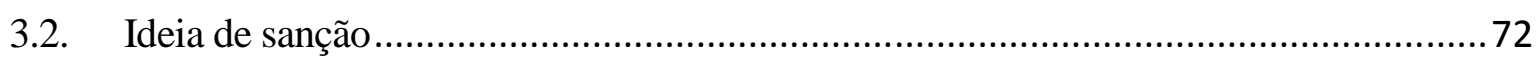

3.3. Sanção e infração administrativas - antecedente e consequente ..................................74

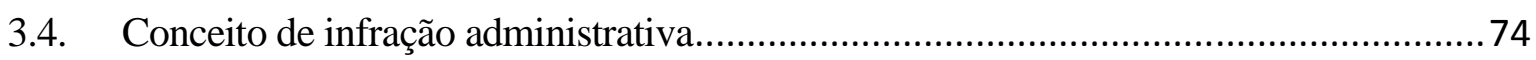




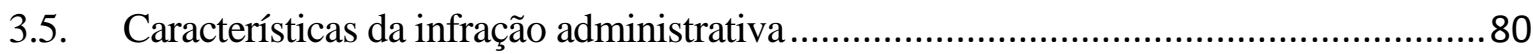

3.5.1. Elemento subjetivo: a autoridade administrativa ............................................. 81

3.5.2. Elemento objetivo: efeito aflitivo da medida em que se exterioriza .......................82

3.5.3. Elemento teleológico: finalidade repressora (punição do infrator) e desestimuladora

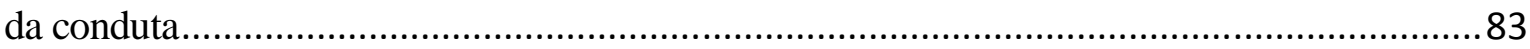

3.5.4. Elemento formal: natureza administrativa do procedimento .................................... 85

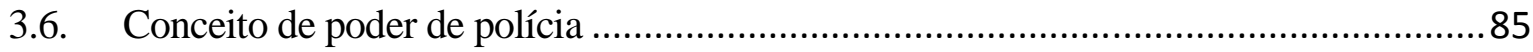

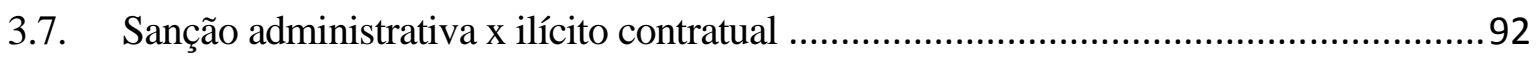

3.8. Delegação legislativa em matéria de infração e sanção administrativas .......................92

3.9. Discricionariedade na aplicação de sanções ........................................................... 94

3.9.1. Tipo formado com conceitos jurídicos indeterminados ........................................95

3.9.2. Mais de uma possibilidade de sanção prevista em lei ............................................. 96

3.9.3. Discricionariedade para não punir....................................................................99

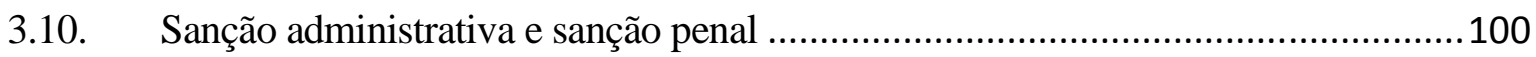

3.11. As sanções administrativas e o princípio da legalidade......................................... 103

4. BANCO CENTRAL COMO AGÊNCIA REGULADORA ..................................... 104

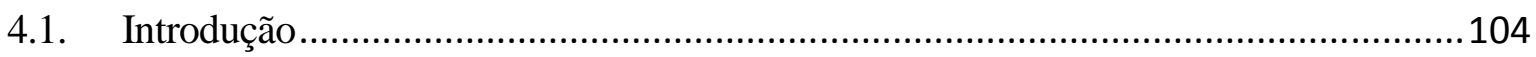

4.2. Modelo regulatório do Sistema Financeiro Nacional: função do CMN e do Banco

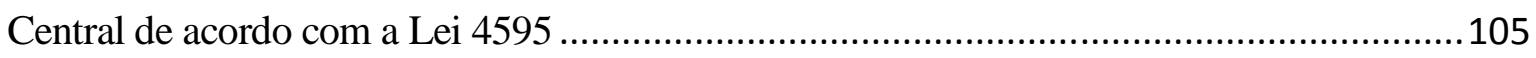

4.3. Recepção da Lei 4595 pela Constituição Federal e ADCT .........................................115

4.4. Teorias sobre o poder regulatório do CMN e BACEN ............................................ 121

4.4.1. Atividade bancária como concessão de serviço público - Arnoldo Wald ..................122

4.4.2. Mutação Constitucional - Tércio Sampaio Ferraz Júnior ......................................127

4.4.3. Regulamentos autorizados e autônomos - Eros Grau............................................. 131

4.4.4. Relação de sujeição especial entre o Banco Central e os agentes do sistema financeiro

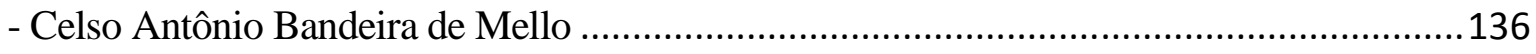

4.5. Previsão de infrações e sanções em ato infralegal ...................................................139

5. SANÇÕES APLICÁVEIS PELO BANCO CENTRAL DO BRASIL .......................141

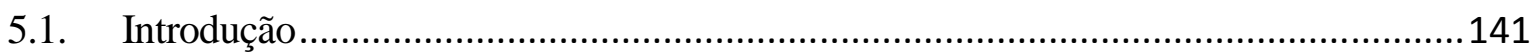

5.2. Classificaçãa das sanções administrativas............................................................142

5.2.1. Grupo 1: a lei apresenta infração e sanção.......................................................... 142 
5.2.2. Grupo 2: a lei prevê infração mas a sanção é vaga................................................ 144

5.2.3. Grupo 3: a lei prevê hipóteses vagas de infração e de sanção administrativa .............146

5.2.4. Grupo 4: infrações e sanções previstas em ato administrativo ..............................147

5.3. Entendimento do Poder Judiciário ..................................................................... 150

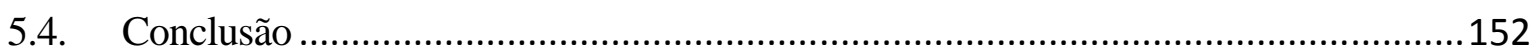

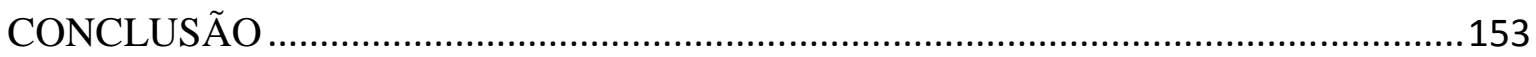

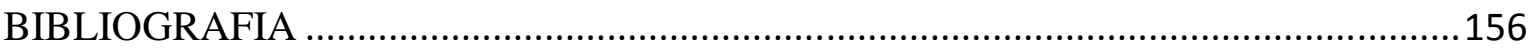




\section{INTRODUÇÃO}

O presente trabalho propõe-se a analisar o poder discricionário do Conselho Monetário Nacional e do Banco Central do Brasil para instituírem, por ato infralegal, sanções administrativas e a sua compatibilidade com os princípios da legalidade e da tipicidade.

A questão é de grande importância pois envolve um questionamento acerca do modelo de regulação do mercado financeiro que engloba a instituição e a aplicação de sanções por autoridades administrativas.

Essas sanções podem afetar tanto as instituições financeiras (alterando a sua capacidade de atuar no mercado) como outros participantes (tais como investidores institucionais). Considerando os valores envolvidos e a inserção do Brasil como país importante na economia global, avaliar os limites da discricionariedade da administração pública contribui para garantir segurança ao mercado financeiro, como afirma Carlos Roberto de Siqueira Castro:

A competência normativa desses órgãos da Administração em tão relevante setor da economia é de tal sorte abrangente que o Congresso Nacional do Brasil praticamente deixou de deliberar nessa matéria, tanto mais, ainda, que os temas de ordem financeira inscreveram-se na iniciativa exclusiva do Presidente da República, cujos projetos são insuscetíveis de emenda congressual de acordo com o art. 57 e parágrafo único da Constituição vigente, o que bem dá mostra do desprestígio a que ficou reduzido nosso Poder Legislativo pelas ditaduras militares. ${ }^{1}$

A questão perpassa a compatibilidade entre um modelo instituído sob regime militar autoritário e o atual modelo democrático desenhado na Constituição de 1988 e suas alterações posteriores.

Independentemente das peculiaridades do Sistema Financeiro Nacional, muitas das reflexões aqui desenvolvidas são plenamente aplicáveis a sanções

\footnotetext{
${ }^{1}$ CASTRO, Carlos Roberto Siqueira. O Congresso e as delegações legislativas. Rio de Janeiro: Forense, 1986, p. 100.
} 
administrativas impostas por outros órgãos, inclusive as denominadas agências reguladoras.

O tema circunscreve-se à discricionariedade e legalidade. Entretanto, embora relevantes e relacionadas ao tema, não constituem objeto do presente trabalho outras questões referentes às sanções administrativas, tais como a questão da culpabilidade do agente, o non bis in idem com outros ilícitos da esfera penal e civil e até mesmo com outras infrações administrativas. Igualmente, deixamos de analisar causas excludentes da ilicitude da infração administrativa, a legítima defesa, estado de necessidade, estrito cumprimento do dever legal, exercício regular do direito e, para alguns, a inexigibilidade de conduta adversa.

Para facilitar a análise, não incluímos a Comissão de Valores Mobiliários no presente trabalho por entendermos que, embora diretamente vinculada ao Conselho Monetário Nacional, em situação paralela à do Banco Central, trata de regulação do mercado de capitais e não do sistema financeiro, o que mereceria um estudo próprio.

O presente trabalho é dividido em cinco capítulos, seguidos por conclusão.

Inicialmente, no Capítulo 1 serão apresentados em linhas gerais os pressupostos metodológicos e normativos.

Em seguida, no Capítulo 2, serão abordados o princípio da legalidade, sua função no ordenamento jurídico e seus fundamentos, a delegação legislativa e a sua compatibilidade com a Constituição de 1988. Ao final, será apresentada a teoria segundo a qual há um regime jurídico de sujeição especial ao Estado sob o qual a legalidade se apresentaria de modo diverso.

No Capítulo 3, será identificado o conceito de infração e de sanção administrativa para diferenciar este regime jurídico de outros afins, como o exercício do poder de polícia em geral, sanções contratuais e indenização por perdas e danos. Também serão abordados os efeitos da legalidade e da tipicidade em matéria de infrações e sanções, especialmente em relação ao poder discricionário e à utilização de termos indeterminados.

No Capítulo 4, serão examinados o contexto e o regime jurídico das agências reguladoras, de modo a se verificar se o Conselho Monetário Nacional e o Banco 
Central podem editar normas com força de lei. Em seguida, serão apresentadas as teorias que defendem a competência de órgãos públicos e agências para baixar normas com força de lei.

No Capítulo 5, será apresentado, de forma sintética, um modelo de classificação das sanções e infrações aplicáveis pelo Banco Central, examinando-se a compatibilidade de cada grupo com os princípios da legalidade e da tipicidade.

Finalmente, serão apresentadas as conclusões em relação aos limites à discricionariedade do Conselho Monetário Nacional e do Banco Central do Brasil para instituírem infrações e sanções administrativas e aplicá-las. 


\section{METODOLOGIA}

\subsection{Dogmática jurídica como sistema de referência}

A premissa adotada é que não constitui conhecimento a produção aleatória de informações. O processo de conhecimento exige a delimitação de um objeto (aquilo que será estudado e descrito) e o respectivo método, assim entendido como a forma de aproximação em relação ao objeto. Além disso, a descrição do objeto sempre se dará em conformidade com o sistema de referência, ou seja, o contexto no qual o estudo e a descrição do objeto são feitos.

O direito, assim entendido como o conjunto das normas de conduta, pode ser estudado sob o aspecto da Justiça, da eficácia, da historicidade e da validade das normas. Ainda que o objeto seja o mesmo, o sistema de referência adotado determina métodos diversos, cada qual utilizado para uma aproximação distinta.

O estudo da norma sob o aspecto da Justiça, por exemplo, consiste em valorar o objeto em correspondência com valores éticos e morais supraconstitucionais e que inspiram o ordenamento jurídico. Trata-se de um problema de deontologia jurídica, como afirma Norberto Bobbio: “o problema se uma norma é justa ou não é um aspecto do contraste entre mundo ideal e mundo real, entre o dever ser e o que é: norma justa é aquela que deve ser; norma injusta é aquela que não deveria ser". ${ }^{2}$

Karl Larenz afirma que esses postulados de justiça são predominantemente definidos por outros ramos do conhecimento que poderão indicar com "suficiente segurança como operará a regulação proposta nos diversos domínios da realidade social, que alternativas na realidade existem objetivamente, quais os meios disponíveis, quais as vantagens e desvantagens que é legítimo esperar". 3

As normas também podem ser avaliadas do ponto de vista da ocorrência do cumprimento espontâneo por seus destinatários e da coação eventualmente imposta.

\footnotetext{
${ }^{2}$ BOBBIO, Norberto. Teoria da norma jurídica. Bauru: Edipro, 2001, p. 46.

${ }^{3}$ LARENZ, Karl. Metodologia da ciência do direito. $3^{\mathrm{a}}$ ed. Lisboa: Fundação Calouste Gulbenkian, 1997, p. 268.
} 
Neste caso, o direito é estudado como fenômeno social, cuja investigação destina-se a averiguar a eficácia da norma com a finalidade histórica ou sociológica.

Também é possível restringir o estudo das normas à sua interação dentro do sistema jurídico em um determinado lugar e tempo. Aqui, a ciência do direito, ou a dogmática, tem como objeto o direito positivo. Este formado exclusivamente por normas jurídicas veiculadas em linguagem, conceituadas como "enunciado prescritivo com conteúdo deôntico de sentido completo integrantes de um sistema", como esclarecido por Lourival Vilanova. $^{4}$

Larenz adverte que, embora as fronteiras das disciplinas que têm o direito por objeto sejam permeáveis entre si, subsiste "o fato de que as suas interrogações são distintas e que cada uma delas desenvolveu e aplica seus métodos próprios para responder às questões que a si própria cada uma delas se coloca". 5

Um plano de referência deve ser constituído de tal forma que as informações e as proposições sejam espelhadas e relacionadas com outras informações e proposições, dentro de um mesmo contexto. Ele delimita o ponto de vista do sujeito cognoscente, os códigos utilizados para ser compreendido pelo interlocutor, o tempo e o espaço considerados na proposição. Somente mediante esse sistema é possível que o receptor da mensagem possa compreender e comprovar as proposições emitidas pelo seu emissor. $^{6}$

O sistema de referência adotado é a dogmática jurídica ${ }^{7}$ restrita ao estudo do direito, enquanto direito positivo, ou seja, o sistema de normas vigentes em um determinando lugar e tempo. De acordo com esse sistema, deve ser verificado se as normas jurídicas são válidas ou não válidas. ${ }^{8}$

\footnotetext{
${ }^{4}$ VILANOVA, Lourival. Estruturas lógicas e o sistema de direito positivo. $3^{\mathrm{a}}$ ed. São Paulo: Noeses, p. 173174.

${ }^{5}$ LARENZ, Karl. Metodologia da ciência do direito. $3^{\mathrm{a}}$ ed. Lisboa: Fundação Calouste Gulbenkian, 1997, p. 264.

${ }^{6}$ CARVAlHO, Paulo de Barros. Direito Tributário: fundamentos da incidência tributária. $3^{\text {a }}$ ed. revista e atualizada. São Paulo: Saraiva, 2004, p. 2-4.

7 Trabalhamos com os conceitos de plano da dogmática e da zetética propostos por Tércio Sampaio Ferraz Júnior em Introdução ao estudo do direito, $4^{\text {a }}$ ed., São Paulo, Atlas, 2003, p. 39-51.

${ }^{8}$ No mesmo sentido: “(...) matéria-prima do jurista, a quem só interessam sistemas de normas e princípios encampados pela ordem jurídica, isto é, enquanto realidades desta província do conhecimento humano"
} 
Para verificação da validade de uma norma esta deve ser justificada de acordo com os preceitos constitucionais do próprio sistema de validade relativos à produção legislativa e examinando-se se o seu conteúdo está de acordo com as exigências a esse respeito e com as normas que lhe dão fundamento. Em outros termos, a norma deve ser confrontada somente com outras normas integrantes do sistema.

Karl Larenz leciona que o jurista não pode com métodos jurídicos submeter a validade de uma norma para além da validade normativa da Constituição. Como já afirmado, a confrontação da norma com valores éticos e morais supraconstitucionais não é questão da dogmática jurídica. Na vigência de direitos fundamentais positivados na Lei Fundamental, na condição de princípios do Estado de Direito, a verificação da conformidade da norma com estes é assim uma questão de interpretação da própria Constituição. ${ }^{9}$

A definição do sistema de referência acima não significa que o intérprete, ao construir, a partir da legislação vigente, a norma aplicável, esteja limitado à investigação dos aspectos semânticos e gramaticais do texto legal. Afinal, conforme Larenz, a aplicação do direito tem como um dos critérios da interpretação o "teleológicoobjetivo" constituído pelos princípios ético-jurídicos, que estão antepostos a uma regulação, no qual a referência de sentido dessa regulação à ideia de Direito se torna apreensível, manifesta ${ }^{10}$, como afirma o autor:

O legislador que estatui uma norma, ou, mais precisamente, que intenta regular um determinado sector da vida por meio de normas, deixa-se nesse plano guiar por certas intenções de regulação e por considerações de justiça ou de oportunidade, às quais subjazem em última instância determinadas valorações. Estas valorações manifestam-se no facto de que a lei confere proteção absoluta a certos bens, deixa outros sem proteção ou protege-os em menor escala; de que quando existe conflito entre os interesses envolvidos na relação da vida a regular faz prevalecer em detrimento do outro, ou considera cada um dentro de um certo âmbito, na imposição ou proibição de

(BANDEIRA DE MELLO, Celso Antônio. Curso de direito administrativo. $28^{\mathrm{a}}$ ed. São Paulo: Malheiros, 2011, p. 59).

${ }^{9}$ LARENZ, Karl. Metodologia da ciência do direito. $3^{\text {a }}$ ed. Lisboa: Fundação Calouste Gulbenkian, 1997, p. 271.

${ }^{10}$ Sobre o elemento teleológico-objetivo: LARENZ, Karl. Metodologia da ciência do direito. $3^{\mathrm{a}}$ ed. Lisboa: Fundação Calouste Gulbenkian, 1997, p. 470. 
certos modos de conduta, na cominação de 'sanções' contra os infratores, na restrição ou negação de direitos, na imputação de riscos. Nestes termos 'compreender' uma norma jurídica requer o desvendar da valoração nela imposta e o seu alcance. A sua aplicação requer o valorar do caso a julgar em conformidade a ela, ou, dito de outro modo, acolher de modo adequado a valoração contida na norma ao julgar o 'caso'.11

Não constitui objetivo do trabalho um estudo aprofundado da obra de Karl Larenz, mas três elementos serão de grande utilidade e servirão para a organização das ideias: (i) substituição da relação de hierarquia por funcionalidade entre os elementos integrantes da interpretação, (ii) a separação entre interpretação e desenvolvimento do direito, (iii) o direito visto como sistema constituído exclusivamente por normas válidas orientado a partir de princípios ético-jurídicos ${ }^{12}$.

\subsection{Relação entre elementos integrantes da interpretação}

A norma jurídica não se confunde com e nem está contida no texto legal. A tarefa do juiz ou intérprete não consiste na simples subsunção do caso concreto a uma norma jurídica previamente dada pelas leis. Savigny já indicava que o trabalho do intérprete é a "reconstrução do direito no âmbito do pensamento". 13

Neste mesmo sentido, cabe trazer a lição de Friedrich Müller, segundo o qual,

(...) a norma jurídica não está contida no código legal. Este contém apenas formas preliminares, os textos das normas. Eles se diferenciam sistematicamente da norma jurídica, que deve ser primeiramente produzida

\footnotetext{
${ }^{11}$ LARENZ, Karl. Metodologia da ciência do direito. $3^{\mathrm{a}}$ ed. Lisboa: Fundação Calouste Gulbenkian, 1997, p. 297-298.

${ }^{12}$ LARENZ, Karl. Metodologia da ciência do direito. $3^{\mathrm{a}}$ ed. Lisboa: Fundação Calouste Gulbenkian, 1997, p. 391-620.

13 "Das ist das Geschäft der Auslegung, dir wir daher bestimmen können als die Reconstruction des dem Gesetze inwohnen den Gedankens" (tradução livre). SAVIGNY, Friedrich Carl von. de. System des heutigen römischen Rechts. Berlin: Veit und Camp, 1840, p. 213.
} 
em cada processo individual de decisão jurídica, i.e., 'trazida para fora' [hervorgebracht]. ${ }^{14}$

Isso não significa que o intérprete deva abandonar o texto legislativo e buscar reconstruir a obra do legislador. Uma vez positivadas, as leis passam a ter existência própria autônoma em relação aos seus autores. Como afirma Hans-Georg Gadamer, "a leitura compreensiva não é repetição de algo do passado, mas participação num sentido presente". 15

Neste processo a interpretação assume um papel central, tendo como particularidade a divisão em quatro elementos, critérios, ou partes constitutivas: o gramatical, o lógico, o histórico e o sistemático ${ }^{16}$, segundo a clássica lição de Savigny ${ }^{17}$, ainda que ele não tivesse em mente aplicá-los ao direito público. ${ }^{18}$

\footnotetext{
${ }^{14}$ MÜLLER, Friedrich. O novo paradigma do direito, introdução à teoria e metódica estruturantes. $2^{\mathrm{a}}$ ed. São Paulo: RT, 2009, p. 149.

${ }^{15}$ GADAMER, Hans-Georg. Verdade e método, traços fundamentais de uma hermenêutica filosófica. $2^{\mathrm{a}}$ ed.
} Petrópolis: Vozes, 1998, p. 571.

${ }^{16}$ SAVIGNY, Friedrich Carl von. de. System des heutigen römischen Rechts. Berlin: Veit und Camp, 1840, p. 212 e seguintes.

${ }^{17}$ Embora escrito há mais de 150 anos, o modelo de interpretação proposto por Savigny, de certo modo, é compatível com as atuais concepções de interpretação, como leciona Reinhold Zippelius: "A teoria da interpretação 'clássica' de Savigny considerava que a tarefa da interpretação consistiria em 'situar-se na perspectiva do legislador e buscar reproduzir para si esta atividade de forma artificial'. Dessa maneira, a interpretação seria 'a reconstrução do pensamento que reside na lei'. Naturalmente, Savigny não se preocupava com os pensamentos íntimos das partes envolvidas no processo legislativo, mas sim com o pensamento que o legislador, como 'representante do espírito do povo' deveria ter. Ao final, não se estaria distante do posicionamento de Savigny, aquele que hoje, partindo de uma compreensão democrática de legitimidade, definisse que: o objetivo da interpretação é atingir a concepção do legislador de uma forma apta ao consenso. A serviço de seu objetivo interpretativo, Savigny fez uso de diferentes critérios interpretativos (meios para a determinação do sentido), nomeadamente, 'gramatical', 'lógico', 'histórico' e 'sistemático' como pontos de referência para a determinação do sentido da lei" (tradução livre). No original: "Die „klassische" Auslegungstheorie Savignys hielt es für die Aufgabe der Auslegung, „,sich in Gedanken auf den Standpunkt des Gesetzgebers (zu) versetzen, und dessen Tätigkeit in sich künstlich (zu) wiederholen“; so sei Auslegung „die Rekonstruktion des dem Gesetze innewohnenden Gedankens“.(1) Freilich ging es Savigny nicht darum, höchstpersönliche Gedanken der am Gesetzgebungsprozeß Beteiligten zu wiederholen, sondern solche Gedanken, die der Gesetzgeber als „Vertreter des Volkssgeistes“ denken mußte. Im Ergebnis wäre man dieser Vorstellung Savignys nicht sehr fern, wenn man heute, von einem demokratischen Legitimitätsverständnis ausgehend, formulieren würde: Auslegungsziel sei es, die Gedanken des Gesetzgebers in einer konsensfähigen Gestalt zu gewinnen. In den Dienst seines Auslegungszieles stellte Savigny verschiedene Auslegungskriterien (Sinnbestimmungsmittel), nämlich „grammatische“, „logische“, „historische“ und „systematische“ Anhaltspunkte für den Sinn des Gesetzes”. ZIPPELIUS, Reinhold. Juristische Methodenlehre, eine Einführung. 6a ed. Munique: C. H. Beck'sche, 1994, p. 39. Grifos no original.

${ }^{18}$ MÜLLER, Friedrich. Metodologia do direito constitucional. $4^{\mathrm{a}}$ ed. São Paulo: RT, 2010, p. 47. 
O elemento gramatical "tem como objeto as palavras servidas pelo legislador para nos comunicar seu pensamento, ou seja, a linguagem das leis". ${ }^{19}$ Esta linguagem é a mesma utilizada em geral tanto pelos autores quanto pelos destinatários das leis, para que estes possam se orientar e aqueles se fazerem compreendidos.

Ainda que se utilize de algum linguajar técnico, a linguagem jurídica não é uma linguagem simbolizada, tal qual as fórmulas matemáticas e os programas de computador. Os símbolos utilizados em fórmulas são previamente convencionados a fim de alcançar uma exatidão. Ao contrário, a linguagem de uso geral, ainda que catalogada em dicionários, é espontânea, pois estabelecida pela prática reiterada e reconhecida pelo grupo e, por esta mesma razão, não alcança a exatidão da linguagem simbolizada.

Muitas vezes, entre os diferentes significados dos termos utilizados nas leis, é possível identificar um núcleo de significado em que não resta dúvida sobre o sentido. Por outro lado, em torno deste núcleo os termos podem compreender fenômenos diversos, de maior ou menor extensão, "que no uso lingüístico geral só algumas vezes se têm também em conta". ${ }^{20}$ Como exemplo, podemos citar o termo "família", que apresenta como núcleo a reunião de casal de sexos opostos com respectivos filhos. Mas, em sentido amplo, pode englobar outros parentes, filhos adotivos, ou até mesmo uniões homoafetivas.

Assim o sentido literal, em razão da falta de exatidão dos termos utilizados nas leis, não é suficiente por si só para a construção da norma jurídica, mas dá início ao processo de interpretação.

O elemento lógico, segundo Savigny, "encontra-se na articulação dos pensamentos e na relação que reúne as diferentes partes". ${ }^{21}$ Ele permite ao intérprete identificar o sentido de cada proposição jurídica enquanto parte da regulação à qual

\footnotetext{
19 "Das grammatische Element der Auslegung hat zum Gegenstand das Wort, welches den Übergang aus dem Denken des Gesetzgebers in unser Denken vermittelt. Es besteht daher in der Darlegung der von dem Gesetzgeber angewendeten Sprachgesetze" (tradução livre). SAVIGNY, Friedrich Carl von. de. System des heutigen römischen Rechts. Berlin: Veit und Camp, 1840, p. 213-214.

${ }^{20}$ LARENZ, Karl. Metodologia da ciência do direito. $3^{\mathrm{a}}$ ed. Lisboa: Fundação Calouste Gulbenkian, 1997, p. 501.

21 "Das logische Element geht auf die Gliederung des Gedankens, also auf das logische Verhältni $\beta$, in welchem die einzelnen Teile desselben zu einander stehen" (tradução livre). SAVIGNY, Friedrich Carl von. de. System des heutigen römischen Rechts. Berlin: Veit und Camp, 1840, p. 214.
} 
pertence, de modo a permitir "uma concordância objetiva entre as disposições legais singulares". 22

Esse relacionamento com outras proposições não se confunde com o elemento sistemático, que tem como referência o ordenamento como um todo, como leciona Reinhold Zippelius:

Esses elementos 'lógicos' da interpretação foram especialmente enfatizados por Savigny. Ele se referia, com isso, às relações lógicas que os elementos de um pensamento jurídico estabelecem entre si. Delas fazem parte as relações sintáticas entre as palavras de uma frase, mas também as conexões lógicas, por meio das quais uma norma concatena-se com definições legislativas e outras determinações complementares, que são a base para a solução de um caso concreto. As (igualmente lógicas) relações de uma norma com o conjunto geral das demais normas do ordenamento jurídico foram denominadas por Savigny, ao contrário, não como elemento 'lógico', mas sim como elemento 'sistemático' da interpretação. ${ }^{23}$ (tradução livre)

Para Larenz, o elemento lógico, que denomina de contexto significativo da lei, abrange também harmonização com a sistemática conceitual que é subjacente à norma jurídica interpretada. O autor apresenta como exemplo a utilização indistinta pelo legislador de termos que, no uso comum, são vistos como sinônimos, mas que constituem institutos jurídicos diversos, como posse e propriedade. Neste caso, o intérprete deve identificar no texto legal a incongruência lógica se o termo for tomado em seu sentido técnico e extrair a norma jurídica com emprego da melhor técnica.

O elemento histórico consiste na intenção reguladora, fins e ideias normativas do legislador histórico. São as decisões valorativas encontradas pelos autores dos textos legais.

\footnotetext{
${ }^{22}$ LARENZ, Karl. Metodologia da ciência do direito. $3^{\mathrm{a}}$ ed. Lisboa: Fundação Calouste Gulbenkian, 1997, p. 458.

${ }^{23}$ No original: "Diese „logischen“ Elemente der Auslegung hob Savigny gesondert hervor. Er meinte damit die logischen Beziehungen, welche die Teile eines Rechtsgedankens miteinander verbinden. Zu ihnen gehören die syntaktischen Zusammenhänge, in denen die einzelnen Wörter eines Rechtssatzes zueinander stehen, aber auch die logischen Zusammenhänge, durch welche eine Norm mit Legaldefinitionen und anderen ergänzenden Bestimmungen zu jenem Gesamttatbestand verbunden wird, welcher der Fallösung zugrunde liegt. Die (gleichfalls logischen) Beziehungen, in denen eine Rechtsnorm zu dem Gesamtzusammenhang der übrigen Normen der Rechtsordnung steht, bezeichnete Savigny hingegen nicht als „logisches“, sondern als „systematisches“ Element der Auslegung”. ZIPPELIUS, Reinhold. Juristische Methodenlehre, eine Einführung. 6 ${ }^{a}$ ed. Munique: C. H. Beck'sche, 1994, p. 40. Grifos no original.
} 
Nos Estados modernos as leis são elaboradas pelos parlamentos, sendo consideradas como vontade do legislador "as idéias normativas da comissão consultiva ou dos relatores ministeriais que tomaram parte na elaboração da lei e, em todo caso, as dos membros da comissão parlamentar". ${ }^{24}$ No Brasil, como exemplo de exteriorização das idéias do legislador histórico, temos a exposição de motivos do Código de Processo Civil, de autoria do então ministro da justiça Alfredo Buzaid.

O elemento sistemático teve alterações desde a sua formulação por Savigny, sendo progressivamente identificado com a ideia de elemento teleológico. O autor aponta que ele constitui "o elo intrínseco que une as instituições e as regras do direito no sentido de formar uma grande unidade". ${ }^{25}$

Claus-Wilhelm Canaris propõe que o elemento sistemático consiste na adequação da interpretação não ao conjunto das demais proposições jurídicas, mas a partir de um modelo de sistema de normas de "ordem axiológica ou teleológica de princípios gerais do direito" 26 , como segue:

Enquanto a interpretação a partir do sistema externo apenas traduz, em certa medida, o prolongamento da interpretação gramatical, a argumentação baseada no sistema interno exprime o prolongamento da interpretação teleológica ou, melhor, apenas um grau mais elevado dentro desta, - um grau no qual se progrida da ratio legis à ratio iuris, e tal como a interpretação teleológica em geral a argumentação a partir do sistema interno da lei coloca-se, com isso, no mais alto nível entre os meios da interpretação. ${ }^{27}$

No mesmo sentido, Larenz denomina de critérios teleológico-objetivos os valores e princípios dados em um ordenamento jurídico pelos quais a própria ideia de direito se manifesta, como mencionado anteriormente. Também engloba as "estruturas do

\footnotetext{
${ }^{24}$ LARENZ, Karl. Metodologia da ciência do direito. $3^{\mathrm{a}}$ ed. Lisboa: Fundação Calouste Gulbenkian, 1997, p. 458.

25 "Das systematische Element endlich bezieht sich auf den inneren Zusammenhang, welcher alle Rechtsinstitute und Rechtsregeln zu einer grossen Einheit verknüpft" (tradução livre). SAVIGNY, Friedrich Carl von. de. System des heutigen römischen Rechts. Berlin: Veit und Camp, 1840, p. 214.

${ }^{26}$ CANARIS, Claus-Wilhelm. Pensamento sistemático e conceito de sistema na ciência do direito. $2^{\mathrm{a}}$ ed. Lisboa: Fundação Calouste Gulbenkian, 1996, p. 77.

${ }^{27}$ CANARIS, Claus-Wilhelm. Pensamento sistemático e conceito de sistema na ciência do direito. $2^{\mathrm{a}}$ ed. Lisboa: Fundação Calouste Gulbenkian, 1996, p. 159. Grifos no original.
} 
âmbito material regulado, dados fatuais"28, que segundo Friedrich Müller constituem o âmbito da norma. ${ }^{29}$ Estes critérios devem ser tomados em consideração pelo intérprete pois a regra jurídica formulada "intenta uma regulação materialmente adequada". 30

A necessidade de adequação da interpretação deriva da própria impossibilidade de estabelecimento prévio de uma única interpretação válida, como propõe Gadamer:

Assim, a interpretação tem de encontrar a linguagem correta, se é que quer fazer que o texto realmente fale. Por isso, não pode haver interpretação correta 'em si', porque em cada caso se trata do próprio texto. A vida histórica da tradição consiste na sua dependência a apropriações e interpretações sempre novas. Uma interpretação correta em si seria um ideal sem pensamentos incapaz de conhecer a essência da tradição. Toda interpretação está obrigada a entrar nos eixos da situação hermenêutica a que pertence. $^{31}$

A inclusão da adequação no processo de interpretação não é novidade. Carlos Maximiliano observa que a hermenêutica preocupa-se, "sobretudo depois que entraram em função de exegese os dados da sociologia, com o resultado provável de cada interpretação". 32 A interpretação, assim, deve buscar "dentro da lei expressa (...) a interpretação que conduza à melhor consequência para a coletividade" ${ }^{33}$, como segue:

Deve o Direito ser interpretado inteligentemente: não de modo que a ordem legal envolva um absurdo, prescreva inconveniências, vá ter a conclusões inconsistentes ou impossíveis. Também se prefere a exegese de que resulte

\footnotetext{
${ }^{28}$ LARENZ, Karl. Metodologia da ciência do direito. $3^{\mathrm{a}}$ ed. Lisboa: Fundação Calouste Gulbenkian, 1997, p. 458.

${ }^{29}$ MÜLLER, Friedrich. O novo paradigma do direito, introdução à teoria e metódica estruturantes. $2^{\mathrm{a}}$ ed. São Paulo: RT, 2009, p. 152.

${ }^{30}$ LARENZ, Karl. Metodologia da ciência do direito. $3^{\mathrm{a}}$ ed. Lisboa: Fundação Calouste Gulbenkian, 1997, p. 471.

${ }^{31}$ GADAMER, Hans-Georg. Verdade e método, traços fundamentais de uma hermenêutica filosófica. $2^{\mathrm{a}}$ ed. Petrópolis: Vozes, 1998, p. 578.

${ }^{32}$ MAXIMILIANO, Carlos. Hermenêutica e aplicação do direito. 20 a ed. Rio de Janeiro: Forense, 2011, p. 135.

${ }^{33}$ MAXIMILIANO, Carlos. Hermenêutica e aplicação do direito. 20ª ed. Rio de Janeiro: Forense, 2011, p. 135.
} 
eficiente a providência legal ou válido o ato, à que tome aquela sem feito, inócua, ou este, juridicamente nulo. ${ }^{34}$

A inclusão da adequação no processo interpretativo não implica na substituição da discricionariedade da Administração Pública (enquanto juízo de conveniência e oportunidade) pela interpretação. O tema será retomado nos capítulos seguintes.

Um dos pontos centrais das teorias da interpretação é identificar se existe ou não uma relação hierárquica a priori entre os elementos da interpretação ou, se não houver, em que condições um deve prevalecer sobre os demais.

Savigny já defendia que os quatro elementos não são espécies distintas de interpretação, entre as quais o intérprete pode escolher ${ }^{35}$. São quatro operações distintas, cuja reunião é indispensável para interpretar a lei, mas uma ou outra pode prevalecer de acordo com as circunstâncias. ${ }^{36}$

Para Karl Larenz não há relação hierárquica entre os elementos ou critérios de interpretação (literal, sistemático, histórico e lógico). Assim, "o peso de cada caso dos diferentes critérios depende, não em último lugar, do modo como se apresentam no caso concreto" 37 .

Robert Alexy reconhece que, ainda que um ou outro autor atual dê ênfase maior ou menor a cada um dos elementos da interpretação, prevalece o entendimento geral de que não é possível o estabelecimento de um critério de prevalência preestabelecido, como segue:

A questão da relação entre os argumentos de formas diferentes é discutida como um problema de estabelecimento de um catálogo de graus ou uma hierarquia dos cânones. Até hoje nenhuma proposta de tal catálogo encontrou reconhecimento geral. A possibilidade, e também a necessidade,

\footnotetext{
${ }^{34}$ MAXIMILIANO, Carlos. Hermenêutica e aplicação do direito. $20^{\mathrm{a}}$ ed. Rio de Janeiro: Forense, 2011, p. 136.

${ }^{35}$ SAVIGNY, Friedrich Carl von. System des heutigen römischen Rechts. Berlin: Veit und Camp, 1840. p. 212-213.

${ }^{36}$ MAXIMILIANO, Carlos. Hermenêutica e aplicação do direito. $20^{\mathrm{a}}$ ed. Rio de Janeiro: Forense, 2011, p. 207-208.

${ }^{37}$ LARENZ, Karl. Metodologia da ciência do direito. $3^{a}$ ed. Lisboa: Fundação Calouste Gulbenkian, 1997, p. 488.
} 
de tal ordenação é valorizada de diferentes maneiras. Segundo Esser, devese 'julgar fracassada a esperança de que se possa indicar um catálogo de graus nas etapas da interpretação'. Kriele apresentou sobre isso uma série de importantes argumentos. Larenz se esforça por conseguir uma certa determinação da relação entre os cânones, mas também chega à conclusão de que não há uma ordem invariável entre as distintas formas. ${ }^{38}$

Assim, uma vez consolidados os entendimentos (i) de que não há predomínio a priori de um critério de interpretação sobre os demais e (ii) de que o texto contido em lei não se confunde com a norma jurídica, mas é o início do processo da sua composição, não há como sustentar que o intérprete do direito deva ater-se à literalidade do texto legal. Pelo contrário, cabe-lhe extrair o sentido da norma a partir de todo o sistema normativo constitucional, tendo como base as ideias do legislador histórico e os princípios ético-jurídicos imanentes à ideia de direito.

Em consequência, o art. 44 da Lei 4.595/64, que dispõe sobre a atribuição, ao Banco Central do Brasil, de competência para impor sanções administrativas, somente pode ser entendido dentro do sistema constitucional em que está inserido e não apenas ou predominantemente pelo aspecto literal do seu texto.

\subsection{Separação entre interpretação e desenvolvimento do direito}

O segundo elemento da metodologia de Karl Larenz, que destacamos acima, considera que a interpretação consiste em um processo de construção do sentido normativo, dentro da margem de variabilidade de significação do próprio texto normativo, ou seja, limitada aos possíveis significados atribuídos a este. Para além disso haverá outro processo: o de desenvolvimento do direito ${ }^{39}$.

Como já demonstrado, o processo de interpretação consiste na construção da norma tendo como referência os textos legais. Os possíveis significados que podem assumir os termos utilizados pelo legislador delimitam este processo de interpretação.

\footnotetext{
38 ALEXY, Robert. Teoria da argumentação jurídica, a teoria do discurso racional como teoria da justificação jurídica. $2^{\mathrm{a}}$ ed. São Paulo: Landy, 2005, p. 241.

${ }^{39}$ LARENZ, Karl. Metodologia da ciência do direito. $3^{\mathrm{a}}$ ed. Lisboa: Fundação Calouste Gulbenkian, 1997, p. 450-454.
} 
Isso não significa que a atuação do juiz esteja limitada pelos aspectos semânticos e sintáticos do texto. $\mathrm{O}$ desenvolvimento consiste em processo distinto da interpretação. Não se busca construir um sentido a partir do texto normativo, mas sim integrar as lacunas decorrentes da ausência de leis que possam ser aplicadas diretamente ao caso ou ainda a correção do direito a fim de dar uma solução diversa da prevista na lei, denominada correção do direito. Neste sentido afirma Karl Larenz:

O uso linguístico geral não é aqui certamente de muitos préstimos. Mas assinala, como sempre, os marcos adentro dos quais tem que estar o significado procurado. $\mathrm{O}$ que está para além do sentido literal linguisticamente possível e é claramente excluído por ele já não pode ser entendido, por via da interpretação, como o significado aqui decisivo deste termo. (...) Uma interpretação que não se situe já no âmbito do sentido literal possível, já não é interpretação, mas modificação do sentido. Com isto não se diz que ela esteja sempre vedada ao juiz; mas necessita de pressupostos especiais e pertence ao âmbito de desenvolvimento patente do Direito, a discutir no próximo capítulo. ${ }^{40}$

No mesmo sentido leciona Reinhold Zippelius:

O limite do sentido literal possível é também o limite da interpretação. Se a jurisprudência quiser ultrapassá-lo, não poderá fazê-lo por meio da interpretação, mas somente por meio da construção jurídica complementadora ou legislativa, especialmente por meio da 'integração de lacunas'. A questão dos limites do âmbito semântico discricionário visa a delimitar quais significados podem ser atribuídos a uma palavra e, nomeadamente - na medida em que a lei não contém nenhuma determinação de significado dissonante qual o significado a ser atribuído de acordo com o emprego linguístico pela comunidade jurídica. Este ‘emprego linguístico’ é a (em regra tácita) convenção sobre o horizonte das noções que uma determinada palavra deve 'significar'. ${ }^{41}$ (tradução livre)

\footnotetext{
${ }^{40}$ LARENZ, Karl. Metodologia da ciência do direito. $3^{\mathrm{a}}$ ed. Lisboa: Fundação Calouste Gulbenkian, 1997, p. 453-454.

41 No original: "Die Grenze des möglichen Wortsinnes ist auch die Grenze der Auslegung. Will die Jurisprudenz sie überschreiten, so kann das nicht durch Interpretation, sondern nur durch gesetzesergänzende oder gesetzesberichtigende Rechtsfortbildung, insbesondere durch „Lückenausfüllung” geschehen. - Die Frage nach den Grenzen des Bedeutungsspiel- raums zielt darauf, welche Bedeutungen einem Wort gerade noch beigelegt werden können, und zwar — soweit das Gesetz keine abweichende Begriffsbestimmung enthält — nach dem Sprachgebrauch der Rechtsgemeinschaft. Dieser „Sprachgebrauch” ist die (regelmäßig
} 
Enquanto for possível extrair do texto legal diferentes sentidos haverá interpretação. Ainda que o termo ou proposição tenha um significado distante do seu núcleo, mas ainda possível de ser assumido, haverá interpretação extensiva, como afirma Karl Engish:

De um modo geral podemos dizer: a analogia insere-se por detrás da interpretação, por detrás mesmo da interpretação extensiva. Se, para a interpretação, se assenta na regra de que ela encontra o seu limite lá onde o sentido possível das palavras já não dá cobertura a uma decisão jurídica (HECK: "O limite das hipóteses de interpretação é o 'sentido possível da letra"'), é neste limite que começa a indagação de um argumento de analogia.

Como critério decisivo para a determinação dos limites entre uma interpretação extensiva, ainda permitida, e uma aplicação analógica, que já não é - determinação essa que, sendo necessária em cada novo caso, é freqüentemente insegura -, temos de novo o sentido literal possível. ${ }^{42}$

Gadamer neste mesmo sentido afirma que interpretação não pode assumir um "comportamento pedagógico, mas a realização da própria compreensão" do texto e, de tal modo, deve ser capaz de desaparecer atrás do que seus termos "fazem falar". 43

Para melhor ilustrar, cabe fazer breve referência ao famoso caso Riggs $v$. Palmer $^{44}$, no qual o Tribunal de Nova Iorque ultrapassou os limites da interpretação e efetuou uma verdadeira correção do direito vigente mediante processo de desenvolvimento, pois a interpretação do texto legal então vigente contrariava princípio segundo o qual ninguém pode se beneficiar da própria torpeza.

stillschweigende) Konvention über den Horizont jener Vorstellungen, die ein bestimmtes Wort „bedeuten” soll. ZIPPELIUS, Reinhold. Juristische Methodenlehre, eine Einführung. $6^{a}$ ed. Munique: C. H. Beck'sche, 1994, p. 43-44.

${ }^{42}$ ENGISCH, Karl. Introdução ao pensamento jurídico. $9^{a}$ ed. Lisboa: Fundação Calouste Gulbenkian, 2004, p. $294-298$.

${ }^{43}$ GADAMER, Hans-Georg. Verdade e método, traços fundamentais de uma hermenêutica filosófica. $2^{\mathrm{a}}$ ed. Petrópolis: Vozes, 1998, p. 580.

${ }^{44}$ Caso submetido à Corte de Nova Iorque sobre a possibilidade de o neto suceder os bens deixados pelo avô, que fora assassinado pelo próprio neto herdeiro. O Tribunal afastou a aplicação da lei, de modo a excluir o neto da sucessão, com base no princípio de que ninguém pode se beneficiar da própria torpeza. Sobre o tema: DWORKIN, Ronald. Levando os direitos a sério. São Paulo: Martins Fontes, 2002, p. 37 e seguintes. 
Importante contribuição para essa diferenciação é dada por Ernst Zeller, ao destacar que, mesmo com a utilização de conceitos indeterminados no texto legal, permanece a separação entre interpretação e desenvolvimento do direito (o que ele denomina "preenchimento de lacuna", mas reconhece que usa no mesmo sentido de “complementação da lei”,45), especialmente em virtude da vinculação dos operadores do direito à lei.

Com esta indicação a diferenciação permanece indeterminada, porém, em decorrência da análise do aspecto linguístico, passa a ser melhor localizável do que até então. Nunca será possível encontrar operações praticamente exatas em sentido matemático tendo em vista a particularidade de conceitos abertos ou indeterminados, qual seja, atuarem como portas de entrada para a adaptação temporal da vigência. Mesmo que não se incluam (o que, em verdade, por sua própria multiplicidade se mostra inevitável) os conceitos abertos ou indeterminados entre as lacunas (chamadas lacunas intra legem, entre outros), as lacunas serão encontradas com muito menos frequência. A separação, como tal, mantém-se íntegra e ganha em repercussão por conta da vinculação de todos os operadores do direito ao direito vigente, e sobretudo por conta do dever de motivação das decisões associado a esta vinculação; isto porque é 'realmente importante que o operador do direito diga o que, de acordo com sua convicção, está fazendo'.

A distinção entre interpretação e integração de lacunas não por meio do significado possível, mas sim por meio de uma 'ratio' da norma (legislativa ou contratual) destacada deste significado também não é viável se se considera o aspecto linguístico dos conceitos abertos ou indeterminados: qual uso linguístico vale no campo semântico associativo é questão a ser esclarecida por meio dos critérios interpretativos; não se sabe se, com isso, poderão ser esclarecidos os objetivos pretéritos ou presentes do agente criador da norma ou dos agentes sujeitos à norma; ainda menos certo é saber se, em verdade, há uma 'ratio' destacada (i) da linguagem e (ii) do ponto de vista dos criadores da norma e dos agentes sujeitos à norma (pretéritos e presentes); mesmo que isto ocorra em certas hipóteses, não é perceptível porque este ponto de vista deveria ser privilegiado; na melhor das hipóteses,

${ }^{45}$ ZELLER, Ernst. Auslegung von Gesetz und Vertrag, Methodenlehre für die juristische Praxis. Zurique: Schulthess Polygraphischer, 1989, p. 155. 
deverá ser considerado como um dos critérios para a necessária determinação do uso linguístico.

Em resumo, pode-se afirmar: a diferença entre interpretação e integração de lacunas deve ser obtida por meio do significado linguístico possível, seja por meio do núcleo semântico, seja por meio do contexto semântico associativo. Não se pode abrir mão desta diferenciação; não é visível qualquer outra diferenciação que respeite adequadamente o aspecto linguístico de leis e de contratos. ${ }^{46}$ (tradução livre)

Esta separação é de grande importância, pois pode ser aplicada na difícil tarefa de identificar os limites do poder regulamentar do Poder Executivo para expedir decretos e regulamentos para "fiel execução" de lei, mediante detalhamento do seu conteúdo. Esta "concreção do próprio sentido"47 (ou interpretação) da lei é incompatível com a inovação no ordenamento jurídico, mediante criação de outras normas, em caráter suplementar ao Legislativo ou ainda correção diante de textos defeituosos. ${ }^{48}$

\footnotetext{
${ }^{46}$ No original: "Die Abgrenzung bleibt auch bei diesem Befund im Fluss, ist aber aufgrund der Analyse der Sprachlichkeit deutlicher als bisher lokalisierbar. Beinahe mathematisch sichere Operationen werden sich angesichts der Eigenheit sprachlich offener Ausdrücke, Einfallstore für Geltungszeit zu sein, nie finden lassen. Zählt man, was bei realistischer Betrachtung allein schon ihrer Vielzahl wegen unumgänglich ist, die sprachlich offenen Ausdrücke nicht zu den Lücken (sog. Lücken intra legem usw.) sind Lücken ohnehin viel seltener anzutreffen. Die Abgrenzung als solche bleibt aber durchaus bestehen und gewinnt ihre volle Tragweite erst aus der Bindung aller Rechtsanwender an das geltende Recht, insbesondere aus der damit zusammenhängenden Begründungspflicht; denn es ist "eben doch wichtig, dass der Rechtsanwender sagt, was er seiner Auffassung nach tut.
}

Auch eine Abgrenzung von Auslegung und Lückenfüllung nicht nach dem möglichen Wortsinn, sondern nach einer davon losgelösten "ratio" der (gesetzlichen oder vertraglichen) Norm ist aufgrund der Uberlegungen zu den sprachlich offenen Ausdrücken nicht durchführbar: Welcher Sprachgebrauch im Bereich der assoziativen Bedeutungsumfelder gilt, ist durch Beizug der weiteren Auslegungskriterien zu klären; ob dabei vergangene oder gegenwärtige Ansichten von Normsetzern oder Normadressaten gefunden werden können, ist ungewiss; noch ungewisser ist es aber, ob eine von Sprache und von Standpunkten von damaligen oder heutigen - Normsetzern bzw. -adressaten gelöste "ratio" bei sprachlich offenen Ausdrücken überhaupt anzutreffen ist; sollte dies in einigen Fällen eintreten, ist aber nicht ersichtlich, weshalb dieser Gesichtspunkt eine Vorzugsstellung innehaben sollte; er ist dann allenfalls als ein Kriterium für die nötige Festlegung zum Sprachgebrauch zu würdigen.

Zusammenfassend lässt sich festhalten: Die Grenze zwischen Auslegung und Lückenfüllung ist anhand des möglichen Wortsinnes, wie er sich im Rahmen des Bedeutungskernes und/oder des assoziativen Bedeutungsumfeldes ergibt, zu ziehen. An dieser Grenzziehung ist festzuhalten; eine andere, der Sprachlichkeit von Gesetzen und Verträgen Rechnung tragende, ist nicht ersichtlich". ZELLER, Ernst. Auslegung von Gesetz und Vertrag, Methodenlehre für die juristische Praxis. Zurique: Schulthess Polygraphischer, 1989, p.154-156. Grifos no original.

${ }^{47}$ GADAMER, Hans-Georg. Verdade e método, traços fundamentais de uma hermenêutica filosófica. $2^{\mathrm{a}}$ ed. Petrópolis: Vozes, 1998, p. 579.

${ }^{48}$ Aqui chamamos de defeituosos os textos que contenham decisões que a Administração entenda não serem os mais apropriados. Não estamos nos referindo a situações que contenham erros no texto, tal como a redação original do art. 65, II, d, da Lei 8.666/93 que mencionava 'área extraordinária' quando se referia a álea 


\subsection{Direito visto como sistema constituído exclusivamente por normas válidas orientado a partir de princípios ético-jurídicos}

O terceiro elemento da metodologia de Karl Larenz, que servirá de base para o trabalho, é a ideia de que o "trabalho juscientífico" consiste na "descoberta de uma unidade interna, de uma contínua conexão de sentido das normas" ${ }^{\text {,49 }}$ dentro de um sistema coerente, como afirma o autor:

Para esse efeito, pressupõe-se sempre que as regras do Direito e os diferentes complexos de regulação estão de fato entre si numa tal conexão de sentido, quer dizer, que são algo mais do que uma aglomeração de normas particulares baseada na 'arbitrariedade' do legislador ou noutros fatores mais ou menos casuais. ${ }^{50}$

Os princípios de justiça, afirma Karl Larenz, "não se obtêm mediante a generalização das regras. Ao contrário, deve-se fazer uma viagem de retorno" ao conjunto dotado de sentido e justificado que dá sentido à própria regulação. ${ }^{51}$

Larenz toma por base o modelo de sistema jurídico proposto por Canaris e constituído por princípios gerais de direito direcionados axiologicamente, como segue:

Nesta ocasião, deve-se recordar de novo a característica principal da idéia de unidade, acima elaborada: a recondução da multiplicidade do singular a alguns poucos princípios constitutivos. Mas isso significa que, na descoberta do sistema teleológico, não se pode ficar pelas 'decisões de conflitos' e dos valores singulares, antes se devendo avançar até aos valores fundamentais

extraordinária no sentido de risco da atividade. Outro exemplo no mesmo diploma está no art. $22, \S 5^{\circ}$, que estabelece o leilão como "modalidade adequada para a alienação de bens 'penhorados'. Mas é claro que o dispositivo alude aos bens 'dados em penhor', figura que corresponde ao verbo 'empenhar'. Ou seja, o leilão aplica-se para bens 'empenhados'. Bem penhorado é aquele apreendido judicialmente, cuja alienação é disciplinada pelo Código de Processo Civil, e não pela Lei de Licitações" ( JUSTEN FILHO, Marçal. Curso de direito administrativo. $5^{\text {a }}$ ed. São Paulo: Saraiva, 2010, p. 165).

${ }^{49}$ LARENZ, Karl. Metodologia da ciência do direito. $3^{\mathrm{a}}$ ed. Lisboa: Fundação Calouste Gulbenkian, 1997, p. 341.

${ }^{50}$ LARENZ, Karl. Metodologia da ciência do direito. $3^{\mathrm{a}}$ ed. Lisboa: Fundação Calouste Gulbenkian, 1997, p. 694.

51 "El principio no se obtiene mediante La generalización de La regla. Es al revés: hay que se hacer un viaje de retorno desde la regulación a los pensamiento de regulación que subyacen bajo ella y desde los cuales la regulación aparece como algo dotado de sentido, y cuando se trata de principios de Derecho justo, como algo justificado". LARENZ, Karl. Derecho justo: fundamentos de ética jurídica. Madrid: Civitas, 1985, p. 35 (tradução livre). 
mais profundos, portanto até aos princípios gerais duma ordem jurídica; trata-se assim de apurar, por detrás da lei e da ratio legis, a ratio iuris determinante. Pois só assim podem os valores singulares libertar-se do seu isolamento aparente e reconduzir-se à procurada conexão 'orgânica' e só assim se obtém aquele grau de generalização sobre o qual a unidade da ordem jurídica, no sentido acima caracterizado, se torna perceptível. O sistema deixa-se assim definir como uma ordem axiológica ou teleológica de princípios gerais do Direito, na qual o elemento de adequação valorativa se dirige mais à característica de ordem teleológica e o da unidade interna à característica dos princípios gerais. ${ }^{52}$

Este modelo de sistema é aplicado ao Direito Tributário por Klaus Tipke e Joachim Lang, que propõem três consequências: (i) a existência de uma unidade de valor da ordem jurídica que afeta os regramentos dos diferentes ramos do direito, (ii) a ruptura desta unidade pelo direito tributário se contrariados os valores fundamentais de outros ramos do direito e (iii) a impossibilidade de o Direito Tributário cancelar ou iludir "valores fundamentais de outros setores do Direito, sempre que isto, por meio da teleologia própria, não esteja suficientemente justificado por uma ponderação de valores". ${ }^{53}$ No mesmo sentido, afirma Ricardo Lobo Torres:

O princípio da unidade é importantíssimo para a interpretação do Direito Tributário, porque significa que o intérprete deve buscar sempre a harmonia, a integração e a sintonia entre as normas e os princípios jurídicos. Atua na interpretação da Constituição Tributária, harmonizando os seus diversos subsistemas e compatibilizando-os com os outros sistemas constitucionais, bem como na do direito tributário de nível ordinário, equilibrando as suas normas e princípios com os dos outros ramos do Direito. O princípio da unidade leva à consideração do Direito Tributário como sistema, mas não como sistema global e fechado de normas e valores. ${ }^{54}$

Maria Sylvia Zanella Di Pietro considera que, por ser o Direito Administrativo de origem pretoriana e não codificado, “os princípios sempre

${ }^{52}$ CANARIS, Claus-Wilhelm. Pensamento sistemático e conceito de sistema na ciência do direito. $2^{\mathrm{a}}$ ed. Lisboa: Fundação Calouste Gulbenkian, 1996, p. 76-78.

${ }^{53}$ TIPKE, Klaus; LANG, Joachim. Direito tributário. Volume 1. Porto Alegre: Sergio Antonio Fabris, 2008, p. 69-70.

${ }^{54}$ TORRES, Ricardo Lobo. Normas de interpretação e integração do Direito Tributário. $3^{\mathrm{a}}$ ed. Rio de Janeiro: Renovar, 2000, p. 61. 
representaram papel relevante nesse ramo do direito, permitindo à Administração e ao Judiciário estabelecer o necessário equilíbrio entre os direitos dos administrados e as prerrogativas da administração". 55

Especificamente no Direito Administrativo, esta necessidade de coerência aponta que as sanções aplicadas pela Administração Pública não podem estar desvinculadas dos princípios e regras gerais aplicáveis às sanções em outros ramos do direito, especialmente no direito penal. A exteriorização do poder de punir do Estado deve estar em consonância com o sistema jurídico vigente, especialmente o princípio da legalidade, que será abordado a seguir.

${ }^{55}$ DI PIETRO, Maria Sylvia Zanella. Direito administrativo. $23^{\text {a }}$ ed. São Paulo: Atlas, 2010, p. 63. 


\section{PRINCÍPIO DA LEGALIDADE}

\subsection{Os princípios no sistema jurídico}

Como apresentado no capítulo antecedente, a norma não se confunde com o texto legal que é submetido ao intérprete. Ela é construída a partir do texto, mas junto com outros elementos de interpretação.

As normas, assim entendidas, compõem o sistema jurídico junto com os valores e podem ser de dois tipos: princípios e regras.

Para alguns autores, como Herbert Hart, em escritos posteriores à obra $O$ conceito de direito, os princípios caracterizam-se pelo grau de generalidade, por serem "amplos, gerais ou inespecíficos, no sentido de que uma série de normas distintas poderia freqüentemente ser apontada como manifestações ou exemplos de um único princípio". 56 $\mathrm{Ou}$ ainda, como afirma Joseph Raz, o termo princípio contém "a ideia de maior generalidade e de maior importância do que a regra". 57

$\mathrm{Na}$ mesma linha, de que o princípio caracteriza-se pelo alto grau de generalidade, cabe destacar José Cretella Júnior, que traz esta ideia para o direito administrativo, como segue:

Os princípios setoriais do direito administrativo - princípios informativos peculiares apenas a este setor - constituem, assim, as proposições básicas deste ramo do direito, garantindo-lhe a autonomia geral e a individualidade dos institutos, estruturados a partir de postulados típicos, diversos dos que informam o direito comum. ${ }^{58}$

\footnotetext{
${ }^{56}$ HART, Herbert Lionel Adolphus. O conceito de direito. São Paulo: Martins Fontes, 2009, p. 335.

57 "Principles and ules are often interchangeably, though the word 'principles' usually carries as implication of greater generality and greater importance than the word 'rules". RAZ, Joseph. Practical reason and norms. $3^{\text {a }}$ ed. reimpressão. New York: Oxford University, 2002, p. 49 (tradução livre).

${ }^{58}$ CRETELLA JÚNIOR, José. Filosofia do direito administrativo. Rio de Janeiro: Forense, 1999, p. 59.
} 
Ronald Dworkin, ao criticar o modelo positivista desenvolvido por Hart, defende que "a diferença entre princípios e normas é de natureza lógica". 59 Os princípios "possuem uma dimensão que as regras não têm - a dimensão do peso e da importância". 60 Assim, a colisão de princípios não implica no reconhecimento da validade de um em detrimento da do outro. Mas importa na identificação de graus distintos de importância de cada um para escolher aquele que irá prevalecer no caso específico, como segue:

Seja como for, somente as regras ditam resultados. Quando se obtém um resultado contrário, a regra é abandonada ou mudada. Os princípios não funcionam dessa maneira; eles inclinam a decisão em uma direção, embora de maneira não conclusiva. E sobrevivem intactos quando não prevalecem. ${ }^{61}$

A partir da linha de Dworkin, Robert Alexy propõe uma distinção qualitativa entre regras e princípios, afirmando que os últimos são mandamentos de otimização porque "ordenam que algo seja realizado na maior medida possível dentro das possibilidades jurídicas e fáticas existentes". ${ }^{62}$ Desse modo, eles não "contêm um mandamento definitivo, mas apenas prima facie". ${ }^{63}$ Assim, Alexy afirma que "a existência de normas de alto grau de generalidade que não são princípios demonstra que o critério da generalidade é apenas relativamente correto". 64

Virgílio Afonso da Silva alerta que o termo princípio é usado pela doutrina pátria geralmente como sinônimo de norma de alto grau de generalidade e que este uso pode implicar em contradições, como segue:

Essas conseqüências, no entanto, passam muitas vezes despercebidas, visto que é comum, em trabalhos sobre o tema, que se proceda, preliminarmente, à distinção entre princípios e regras com base nas teorias de Dworkin ou

\footnotetext{
${ }^{59}$ DWORKIN, Ronald. Levando os direitos a sério. São Paulo: Martins Fontes, 2002, p. 39.

${ }^{60}$ DWORKIN, Ronald. Levando os direitos a sério. São Paulo: Martins Fontes, 2002, p. 42-43.

${ }^{61}$ DWORKIN, Ronald. Levando os direitos a sério. São Paulo: Martins Fontes, 2002, p. 57.

62 ALEXY, Robert. Teoria dos direitos fundamentais. Tradução de Virgílio Afonso da Silva. São Paulo: Malheiros, 2008, p. 90.

63 ALEXY, Robert. Teoria dos direitos fundamentais. Tradução de Virgílio Afonso da Silva. São Paulo: Malheiros, 2008, p. 104. Grifos no original.

${ }^{64}$ ALEXY, Robert. Teoria dos direitos fundamentais. Tradução de Virgílio Afonso da Silva. São Paulo: Malheiros, 2008, p. 109.
} 
Alexy, ou em ambas, para que seja feita, logo em seguida, uma tipologia dos princípios constitucionais, nos moldes das concepções que acima chamei de mais tradicionais. Há, contudo, uma contradição nesse proceder. Muito do que as classificações tradicionais chamam de princípio, deveria ser, se seguirmos a forma de distinção proposta por Alexy, chamado de regra. Assim, falar em princípio do nulla poena sine lege, em princípio da legalidade, em princípio da anterioridade, entre outros, só faz sentido para as teorias tradicionais. Se se adotam os critérios propostos por Alexy, essas normas são regras, não princípios. Todavia, mesmo quando se diz adotar a concepção de Alexy, ninguém ousa deixar esses 'mandamentos fundamentais' de fora das classificações dos princípios para incluí-los na categoria das regras. ${ }^{65}$

De fato, as duas concepções de princípios situam-se em planos distintos, razão pela qual, em determinados casos, pode haver contradição. Por outro lado, como leciona Larenz, os princípios são normas de grande relevância para o ordenamento jurídico que podem transformar-se em regras. ${ }^{66}$ Uma mesma vedação pode configurar um princípio ou estar contida em uma regra derivada deste. Assim, considerando que os modelos de princípios de Dworkin e de Alexy não apresentam como critério de distinção o conteúdo da norma, mas apenas a sua estrutura normativa, um princípio e uma regra podem ter conteúdos semelhantes.

Para melhor exemplificar, o conteúdo do que é geralmente definido por princípio da legalidade, que consiste genericamente na vedação de imposição de obrigações sem previsão legal, pode estar em uma norma ou em um princípio. Sem atribuir um nome específico, o próprio Alexy menciona, como exemplo de um princípio formal, “o princípio que sustenta que as decisões relevantes para a sociedade devem ser tomadas pelo legislador democrático". ${ }^{67}$ Este enunciado não é outra coisa do que o próprio conteúdo do

\footnotetext{
${ }^{65}$ SILVA, Virgílio Afonso da. Princípios e regras: mitos e equívocos acerca de uma distinção. Revista Latino-Americana de Estudos Constitucionais 1. Belo Horizonte: Del Rey, 2003, p. 613. Grifos no original.

${ }^{66}$ LARENZ, Karl. Derecho justo: fundamentos de ética jurídica. Madrid: Civitas, 1985, p. 32-33.

${ }^{67}$ ALEXY, Robert. Teoria dos direitos fundamentais. Tradução de Virgílio Afonso da Silva. São Paulo: Malheiros, 2008, p. 138.
} 
princípio da legalidade. ${ }^{68}$

Conforme leciona Norberto Bobbio, os princípios têm uma função interpretativa, integrativa, diretiva e limitativa, vinculando todo o ordenamento jurídico, como segue:

Em uma perspectiva mais ampla que tentamos dar a partir daqui ao uso dos princípios gerais, podem-se distinguir quatro funções: $1^{\mathrm{a}}$ interpretativa, que é aquela desempenhada, por exemplo, pelos princípios fundamentais inscritos na nossa Constituição, os quais devem servir para resolver, mais em um sentido do que em outro, dúvidas surgidas a partir da interpretação de nomes particulares; $2^{\text {a }}$ suplementar, que é aquela à qual se refere preferencialmente o $2^{\circ}$ parágrafo do art. 12 citado anteriormente e o art. $3,1^{\circ}$ parágrafo, do Estatuto da Corte Internacional de Justiça (ou Tribunal Internacional de Justiça). E é a mais reconhecida; $3^{\text {a }}$ normativa, própria dos princípios programáticos da Constituição, os quais devem inspirar e ordenar o trabalho do legislador ordinário, e, em geral, de todos os órgãos inferiores de produção jurídica; $4^{\mathrm{a}}$ restritiva, é aquela desdobrada pelos 'princípios fundamentais estabelecidos pelas leis do Estado', prevista no art. 117 da Constituição [Italiana], relativa às normas legislativas provindas das Regiões. Fala-se também de uma função sistemática ou construtiva, própria dos princípios gerais, independentemente de sua natureza ou procedência no trabalho da doutrina. Mas aqui, focam-se somente as várias especificações de sua função normativa, ou seja, enquanto normas diretas ou indiretas da conduta. A crescente importância que os princípios gerais vêm recebendo na legislação e na jurisprudência deriva do reconhecimento de sua função ao mesmo tempo de propulsores e delimitadores ao ápice de um sistema: o que não exclui, por outro lado, a função unificadora no campo exclusivamente doutrinário. ${ }^{69}$ (tradução livre)

\footnotetext{
${ }^{68}$ Assim, mesmo cientes dessa distinção entre regra e princípio, será utilizada indistintamente a expressão princípio da legalidade, ainda que no caso possa se tratar de uma regra.

69 No original: "Nello sguardo più ampio che abbiamo cercato di dare sin qui all'impiego dei princìpi generali, si possono distinguere quattro funzioni: $1^{\circ}$ interpretativa, qual'è quella svolta, ad es., dai princìpi fondamentali, iscritti nella nostra Costituzione, i quali debbono servire a far risolvere in un senso piuttosto che in un altro dubbi sorti nell'interpretazione di norme particolari (6); $2 .^{\circ}$ integrativa, qual'è quella cui si riferisce prevalentemente il 2. ${ }^{\circ}$ comma dell'art. 12 predetto e l'art. 38, 1, c, dello Statuto della Corte internazionale di giustizia, ed è la più riconosciuta; $3 .^{\circ}$ direttiva, propria dei princìpi programmatici della Costituzione, i quali dovrebbero ispirare ed orientare l'opera del legislatore ordinario, e in genere tutti gli
} 
Os princípios assumem esta função de orientação e direcionamento do ordenamento jurídico, pois apresentam seus valores fundamentais. As doutrinas mais modernas, como a de Claus-Wilhelm Canaris, chegam a definir o sistema jurídico como uma “ordem axiológica ou teleológica de princípios gerais de Direito, na qual o elemento de adequação valorativa se dirige mais à característica de ordem teleológica e o da unidade interna à característica dos princípios gerais". ${ }^{70}$

Portanto, hoje não há como analisar qualquer regime jurídico senão dentro de um sistema jurídico integrado e ordenado pelos princípios gerais do direito, entre os quais o da legalidade e da tipicidade.

\subsection{Fundamentos do princípio da legalidade}

Historicamente, buscou-se estabelecer que o ideal de justiça fosse garantido por meio da impessoalidade da lei. Carl Schmitt, por exemplo, apresenta um modelo de Estado de Direito identificado com Estado Legiferante, em que a garantia da ordem é a generalidade e isonomia propiciadas pela aplicação da lei e não pela imposição dos interesses pessoais dos governantes:

Domínio e puro poder simplesmente deixam de existir por completo. Quem exerce poder e domínio age 'com base em uma lei' ou 'em nome da lei'. Apenas faz valer, com legitimidade, uma norma vigente. As leis são criadas por uma instância legiferante que, todavia, não governa e também não aplica nem faz valer, ela própria, suas leis. Cabe-lhe, portanto, apenas compor as normatizações vigentes, em cujo nome instâncias públicas subordinadas à lei e responsáveis por sua aplicação têm o direito de comandar o poder estatal.

organi inferiori di produzione giuridica; $4 .^{\circ}$ limitativa, qual'è quella esplicata dai 'princìpi fondamentali stabiliti dalle leggi dello Stato' prevista dall'art. 117 Cost. rispetto alle norme legislative emanate dalle Ragioni. Alcuni parlano anche di una funzione sistematica o costruttiva, propria dei principi generali, quale che sia la loro natura o provenienza nell'opera della dottrina. Ma que si ha riguardo soltanto alle varie epecificazioni della loro funzione normativa, cioè inquanto norme, dirette o indirette, della condotta. La crescente importanza che si viene riconoscendo ai princìpi generali nella legislazione e nalla giurisprudenza deriva dal reconnoscimento della loro funzione insieme propellente e dellimitante al vertice di un sistema: la quale non esclude peraltro la funzione unificante in campo più strettamente dottrinale". BOBBIO, Norberto. Principi generali di diritto. Novissimo digesto italiano. Torino: Editrice Torinese, 1957, volume 13, p. 895896. Grifos no original.

${ }^{70}$ CANARIS, Claus-Wilhelm. Pensamento sistemático e conceito de sistema na ciência do direito. $2^{\mathrm{a}}$ ed. Lisboa: Fundação Calouste Gulbenkian, 1996, p. 77-78. 
(...) O último e verdadeiro sentido do 'princípio' fundamental de 'legalidade' de toda e qualquer vida estatal consiste, enfim, em que não mais se imponham, de maneira alguma, poderes e ordens, afinal de contas, somente se pode fazer valer normas impessoalmente vigentes. ${ }^{71}$

Norberto Bobbio menciona o ideal de norma jurídica caracterizado pela generalidade e pela abstração enquanto requisitos essenciais à realização da justiça:

A principal garantia da máxima que se desejaria fosse o fundamento do nosso ordenamento jurídico: 'A lei é igual para todos', é, indubitavelmente, a generalidade da norma, isto é, o fato de que a norma se dirija não àquele ou a este cidadão, mas à totalidade dos cidadãos, ou então a um tipo abstrato de operador na vida social. Quanto à prescrição abstrata, ela é considerada como a única capaz de realizar um outro fim a que tende todo ordenamento civil: a certeza. Por 'certeza' se entende a determinação, de uma vez por todas, dos efeitos que o ordenamento jurídico atribui a um dado comportamento, de modo que o cidadão esteja em grau de saber, com antecedência, as conseqüências das próprias ações. Agora, esta exigência é maximamente satisfeita quando o legislador não abandona a regulamentação dos comportamentos ao arbítrio do juiz, caso a caso, mas estabelece com uma norma a regulamentação de uma ação-tipo, de modo que ali adentrem todas as ações concretas inclusas naquele tipo. Assim como a generalidade da norma é garantia da igualdade, a abstração é garantia de certeza. ${ }^{72}$

Hans Kelsen propôs a estrutura escalonada da ordem jurídica, segundo a qual a validade de uma norma é fundamentada em outra norma de nível superior que lhe legitima, como segue:

A ordem jurídica não é um sistema de normas jurídicas ordenadas no mesmo plano, situadas umas ao lado das outras, mas é uma construção escalonada de diferentes camadas ou níveis de normas jurídicas. A sua unidade é produto da conexão de dependência que resulta no fato de a validade de uma norma, que foi produzida de acordo com outra norma, se apoiar sobre essa

\footnotetext{
${ }^{71}$ SCHMITT, Carl. Legalidade e legitimidade. Belo Horizonte: Del Rey, 2007, p. 2-3.

${ }^{72}$ BOBBIO, Norberto. Teoria da norma jurídica. Bauru: Edipro, 2001. 182-183
} 
outra norma, cuja produção, por sua vez, é determinada por outra e assim por diante, até abicar finalmente na norma fundamental - pressuposta. ${ }^{73}$

Entretanto, não é a generalidade e isonomia, ou a generalidade $e$ abstração ou ainda uma estrutura escalonada da ordem jurídica que isoladamente podem servir para identificar a lei e diferenciá-la de outras normas que, embora semelhantes sob estes aspectos, não têm a aptidão de produzir os mesmos efeitos que a lei, especialmente o de inovar no sistema jurídico a fim de restringir o exercício de direitos. O que diferencia a lei é que esta consiste no reconhecimento da necessidade da renúncia de parte dos direitos individuais em favor de um interesse da coletividade, por meio de seus legítimos representantes. Por isso, o princípio da legalidade consiste no próprio fundamento do Estado de Direito não somente sob o aspecto formal (propiciando a segurança jurídica mediante o estabelecimento de regras gerais e abstratas), mas, principalmente, porque se constitui na forma pela qual é instituída a supremacia da vontade popular.

O princípio da legalidade é o 'cerne essencial' do Estado de Direito, que, de acordo com Manuel Gonçalves Ferreira Filho, "veio a atender ao clamor de 'governo de leis, não de governantes"” e busca "proscrever o arbítrio do governante, que era um dos principais fatores de indignação contra a monarquia absoluta" ${ }^{74}$ Somente neste contexto é possível compreender seu significado e a sua extensão, sob o risco de equivocado entendimento de que se trata apenas de mera formalidade ou de um protocolo a ser seguido.

Assim, enquanto princípio, a legalidade informa todo o ordenamento jurídico de modo a permitir a realização de dois valores fundamentais, que são a liberdade e a segurança jurídica. Da liberdade deriva a necessidade de separação de poderes com a finalidade de restringir o abuso de poder, de autoconsentimento dos destinatários e a de função administrativa.

\footnotetext{
${ }^{73}$ KELSEN, Hans. Teoria pura do direito. $7^{\mathrm{a}}$ ed. São Paulo: Martins Fontes, 2006, p. 247.

${ }^{74}$ FERREIRA FILHO, Manoel Gonçalves. Princípios fundamentais de direito constitucional. $2^{\mathrm{a}}$ ed. São Paulo: Saraiva, 2010, p. 5.
} 


\subsubsection{Separação de poderes com a finalidade de restringir o abuso de poder}

Com o propósito de impedir o arbítrio no uso do poder estatal, surgem no século XVIII as ideias iluministas para instituição de um novo modelo de Estado. Estas ideias têm como fundamento o princípio da separação dos poderes. ${ }^{75}$

Montesquieu propõe que o exercício das atividades de legislação, de implementação de políticas (executivo) e de julgamento seja feito por pessoas e órgãos estatais distintos e alerta para a necessidade de se impedir que a mesma pessoa ou órgão acumule mais de uma função:

Existem em cada Estado três tipos de poder: o poder legislativo, o poder executivo das coisas que dependem do direito das gentes e o poder executivo daquelas que dependem do direito civil.

Com o primeiro, o príncipe ou o magistrado cria leis por um tempo ou para sempre e corrige ou anula aquelas que foram feitas. Com o segundo, ele faz a paz ou a guerra, envia ou recebe embaixadas, instaura a segurança, previne invasões. Com o terceiro, ele castiga os crimes, ou julga as querelas entre os particulares. Chamaremos a este último poder de julgar e ao outro simplesmente poder executivo do Estado.

A liberdade política, em um cidadão, é esta tranqüilidade de espírito que provém da opinião que cada um tem sobre a sua segurança; e para que se tenha esta liberdade é preciso que o governo seja tal que um cidadão não possa temer outro cidadão.

Quando, na mesma pessoa ou no mesmo corpo de magistratura, o poder legislativo está reunido ao poder executivo, não existe liberdade; porque se pode temer que o mesmo monarca ou o mesmo senado crie leis tirânicas para executá-las tiranicamente.

Tampouco existe liberdade se o poder de julgar não for separado do poder legislativo e do executivo. Se estivesse unido ao poder legislativo, o poder sobre a vida e a liberdade dos cidadãos seria arbitrário, pois o juiz seria

\footnotetext{
${ }^{75}$ Montesquieu utiliza o termo pourvoir (faculdade ou função) e o termo puissance (direito ou autoridade). Embora os termos não sejam sinônimos, apenas por questão metodológica utilizaremos o termo "poder" para nos referirmos a ambas as palavras, indistintamente.
} 
legislador. Se estivesse unido ao poder executivo, o juiz poderia ter a força de um opressor.

Tudo estaria perdido se o mesmo homem, ou o mesmo corpo dos principais, ou dos nobres, ou do povo exercesse os três poderes: o de fazer as leis, o de executar as resoluções públicas e o de julgar os crimes ou as querelas entre os particulares. ${ }^{76}$

Mas não se pode conceber que a proposta de Montesquieu de separação de poderes existe por si só, é necessário observar que ela se inscreve em um contexto de busca de controle do autoritarismo a fim de assegurar as liberdades fundamentais, como afirma o próprio autor: "para que não se possa abusar do poder, é necessário que, pela disposição das coisas, o poder limite o poder". ${ }^{77}$

Como assevera José Afonso da Silva, é da essência do Estado de Direito a tripartição dos poderes, sujeitando toda a atividade do Estado à lei, esta última:

(...) entendida como expressão da vontade geral, que só se materializa num regime de divisão de poderes em que ela seja o ato formalmente criado pelos órgãos de representação popular, de acordo com o processo legislativo estabelecido na Constituição. ${ }^{78}$

No mesmo sentido cabe destacar lição de Canotilho:

O princípio da legalidade da administração, sobre o qual insistiu sempre a teoria do direito público e a doutrina da separação dos poderes, foi erigido, muitas vezes, em 'cerne essencial' do Estado de direito. Postulava, por sua vez, dois princípios fundamentais: o princípio da supremacia ou prevalência da lei (Vorrang des Gesetzes) e o princípio da reserva de lei (Vorbehalt des Gesetzes). Estes princípios permanecem válidos, pois num Estado democrático-constitucional a lei parlamentar é, ainda, a expressão privilegiada do princípio democrático (daí a sua supremacia) e o instrumento

\footnotetext{
${ }^{76}$ MONTESQUIEU, Charles de Secondat. O espírito das leis. São Paulo: Martins Fontes, 2000, p. 167-168.

${ }^{77}$ MONTESQUIEU, Charles de Secondat. O espírito das leis. São Paulo: Martins Fontes, 2000, p. 166.

${ }^{78}$ SILVA, José Afonso da. Curso de direito constitucional positivo. 28 a ed. São Paulo: Malheiros, 2007, p. 420 .
} 
mais apropriado e seguro para definir os regimes de certas matérias, sobretudo dos direitos fundamentais e da vertebração democrática do Estado (daí a reserva da lei). ${ }^{79}$

Embora este modelo tenha servido de inspiração para muitas Constituições, jamais foi praticado de uma forma pura. Mesmo quando o próprio texto constitucional declara por princípio a separação de poderes, o que se verifica é uma forte interpenetração das atribuições, especialmente para a finalidade de controle dos poderes. Como afirma Dalmo de Abreu Dallari, "ou o órgão de um dos poderes pratica atos que, a rigor, seriam de outro, ou se verifica a influência de fatores extralegais, fazendo com que algum dos poderes predomine sobre os demais, guardando-se apenas a aparência de separação". 80

Manoel Gonçalves Ferreira Filho igualmente afirma que "a tripartição nunca excluiu que o poder preponderante investido de uma delas não exercesse parcialmente as outras, (...) sempre implicou, na sua expressão constitucional concreta, exceções, às quais a prática política acrescentou muitas outras". 81

Assim, o princípio da legalidade surge com a tripartição das funções estatais, de modo que é possível afirmar que as mesmas são interdependentes.

\subsubsection{Autoconsentimento dos destinatários da norma}

Em consonância com o ideal de liberdade, o ser humano nasce titular de liberdades fundamentais que não podem ser restringidas pelos demais, mesmo por meio do ordenamento jurídico. Neste sentido afirma John Rawls:

Cada pessoa possui uma inviolabilidade fundada na justiça que nem mesmo

o bem-estar da sociedade como um todo pode ignorar. Por essa razão, a

${ }^{79}$ CANOTILHO, José Joaquim Gomes. Direito constitucional e a teoria da Constituição. $3^{\text {a }}$ ed. Coimbra: Almedina, 1999, p. 251.

${ }^{80}$ DALLARI, Dalmo de Abreu. Elementos de teoria geral do Estado. $26^{\mathrm{a}}$ ed. São Paulo: Saraiva, 2007, p. 221.

${ }^{81}$ FERREIRA FILHO, Manoel Gonçalves. Princípios fundamentais de direito constitucional. $2^{\mathrm{a}}$ ed. São Paulo: Saraiva, 2010, p. 259. 
justiça nega que a perda da liberdade de alguns se justifique por um bem maior partilhado por outros. ${ }^{82}$

O princípio da legalidade nasce com o surgimento do Estado de Direito, como forma de expressão da sociedade representada em regime democrático, com a extinção do Estado absolutista. Por isso, o princípio da legalidade ${ }^{83}$ tem como "certidão de nascimento" o Bill of Rights, de 1689, que afirmava que nenhuma prestação poderia ser instituída sem a aprovação do parlamento:

É ilegal a cobrança de tributos pela Coroa ou para o seu uso, por pretexto de suas prerrogativas, sem autorização do Parlamento, ou em prazo além ou de modo diverso do permitido pelo mesmo) ${ }^{84}$ (tradução livre)

A origem do princípio remonta à Idade Média, época em que, inicialmente pelo direito consuetudinário, posteriormente por imposição dos barões feudais, o consentimento era condição para a imposição dos ônus feudais. ${ }^{85}$ Mas não se tratava ainda propriamente do princípio da legalidade, entre outras razões, porque não havia qualquer órgão representativo da população semelhante a um parlamento. O que era inicialmente o consentimento das corporações deu origem, na vigência do Estado de Direito, após a ditadura de Cromwell, ao princípio da legalidade.

Ferreiro Lapatza destaca que o princípio da legalidade historicamente tem origem na ideia de autonomização, segundo a qual cabe a uma sociedade livre:

\footnotetext{
${ }^{82}$ RAWLS, John. Uma teoria da justiça. São Paulo: Martins Fontes, 1997, p. 4.

${ }^{83}$ UCKMAR, Victor. Principi Comuni di Diritto Costituzionale Tributario. Padova: CEDAM, 1959, p. 13.

${ }^{84}$ No original: "Levying money for or to the use of the Crown by pretense of prerogative, without grant of Parliament, for longer time or in other manner than the same is or shall be granted is illegal" MAITLAND, Frederic Willian; FISHER, Herbert Albert Laurens. The constitutional history of England: a course of lectures. Nova Jersey: Lawbook Exchange, 2001, p. 309.

${ }^{85}$ A Magna Carta, por exemplo, é tida por muitos autores como originária do princípio da legalidade, porém ela apenas impunha o prévio consentimento dos barões para que fossem instituídos os scutge, que, segundo Uckmar, "come è noto, era quanto doveva correspondersi per al mancata prestazione di servizi militari, mentre gli aids come si desume dal significato letterale della parola, erano i sussidi versati per aiutare il re a fronteggiare spese straordinarie: si trattava di oneri feudali che bem poco avevano di comune com le nostre imposte"" (Como é sabido, era o quanto devido em decorrência de uma prestação de serviços militares malsucedida, enquanto o 'aids', como pode ser visto a partir do significado literal da palavra, eram os subsídios pagos para ajudar o rei a atender a despesas extraordinárias: tratava-se de encargos feudais que tinham muito pouco em comum com os nossos impostos - tradução livre) UCKMAR, Victor. Principi Comuni di Diritto Costituzionale Tributario. Padova: CEDAM, 1959, p. 11. No mesmo sentido: BREAY, Claire. Magna Carta, manuscripts and myths. $2^{\mathrm{a}}$ ed. London: Britsh Library, 2010, p. 28-33.
} 
(...) se impor a si mesma as normas que definem delitos e penas, e só a comunidade pode se impor a si mesma as normas que determinam os tributos, isto é, a quantidade com que cada um de seus membros deve sustentar os gastos da coletividade. ${ }^{86}$

Esclarece o autor que nos atuais ordenamentos democráticos baseados em uma separação de poderes "a Lei representa a vontade de autonomização de uma coletividade que não reconhece outros poderes além daqueles que emanam do conjunto de cidadãos que fazem parte dela". ${ }^{87}$

O consentimento dos próprios destinatários das normas restritivas de direito não somente é a própria razão da noção de princípio da legalidade, mas também da democracia, ideia esta originada do pensamento de Rousseau e que teve grande influência na formação do Estado de Direito, como leciona Celso Antônio Bandeira de Mello:

A grande novidade do Estado de Direito certamente terá sido subjugar totalmente a ação do Estado a um quadro normativo, o qual se faz, assim, impositivo para todos - Estado e indivíduos. Se fossem buscadas as raízes produtoras da feição própria do Estado de Direito, poder-se-ia encontrar a seguinte matriz: O Estado de Direito é resultante da confluência de duas vertentes de pensamento: o pensamento de Montesquieu e o pensamento de Rousseau.

Com efeito, o pensamento de Jean Jacques Rousseau, que em sua última e derradeira instância se apóia na idéia da igualdade, sustenta a soberania popular. Sendo todos os homens iguais, todo o poder a eles pertenceria. O Estado receberia parcelas de poder deferidas pelos vários indivíduos. De sorte que a origem, a justificação do poder, não mais residiria em algum direito divino, ou na simples positividade derivada da força, mas, pelo contrário, seria uma resultante direta da vontade consonante dos vários indivíduos que compõem o todo social. É a idéia da soberania popular, é a idéia de democracia. ${ }^{88}$

\footnotetext{
${ }^{86}$ FERREIRO LAPATZA, José Juan. Direito tributário: teoria geral do tributo. Barueri: Manole, 2007, p. 9.

${ }^{87}$ FERREIRO LAPATZA, José Juan. Direito tributário: teoria geral do tributo. Barueri: Manole, 2007, p. 8.

${ }^{88}$ BANDEIRA DE MELLO, Celso Antônio, Discricionariedade e controle jurisdicional, 2. ed. 9 tiragem. São Paulo: Malheiros, 2008, p. 11.
} 
Dalmo de Abreu Dallari igualmente leciona que o autoconsentimento é elemento necessário em uma democracia:

Um dos elementos substanciais da democracia é a prevalência da vontade do povo sobre a de qualquer indivíduo ou grupo. Quando um governo, ainda que bem intencionado e eficiente, faz com que sua vontade se coloque acima de qualquer outra, não existe democracia. Democracia implica autogoverno, e exige que os próprios governados decidam sobre as diretrizes políticas fundamentais do Estado. ${ }^{89}$

Em virtude das condições materiais, não é possível reunir todos os destinatários da norma em assembleia para deliberações diversas, mas o autoconsentimento assume uma forma de exercício por meio da representatividade que reflita da melhor forma possível os diversos grupos, inclusive minoritários. ${ }^{90}$ Nesse sentido afirma Garcia de Enterría:

Mas a legalidade da qual aqui se trata é a que postula a ordem política que sai da Revolução [Francesa], é uma legalidade algo mais que organizadora. Por uma parte, porque essas leis se apresentam como um produto das Câmaras [do Legislativo], onde está localizado o princípio da representação política, de outro lado porque, por essa mesma origem da lei, se trata de uma heteroordenação, de onde se manifestam a legitimação e a apropriação do poder, que em último termo se remetem aos cidadãos. (...) O cidadão não é um simples destinatário da ação administrativa, não é um simples instrumento do poder, está na origem do poder, como sabemos, uma vez que é sua a criação legal (mediante a representação política). ${ }^{91}$ (tradução livre)

${ }^{89}$ DALLARI, Dalmo de Abreu. Elementos de teoria geral do Estado. 26 a ed. São Paulo: Saraiva, 2007, p. 309.

90 SARTORI, Giovanni. Engenharia constitucional: como mudam as constituições. Brasília: UnB, 1996, p. $18-24$.

${ }^{91}$ No original: "Pero la legalidad de que aquí se trata es la que postula el orden político que sale de la Revolución, es una legalidad algo más que organizativa. Por una parte, porque esas leyes se presentan como um producto de las Cámaras, donde está localizado el principio de la representación política; por otra parte, porque, por ese mismo origen de la Ley, se trata de una heteroordenación, donde se manifiesta la legitimación y la apropiación del poder, que en último término remite a los ciudadanos. (...) El ciudadano no es un simple destinatario de la acción administrativa, no es un simple instrumento del poder, está en el origen del poder; lo hemos visto puesto que suya (mediante la representación política) es la creación legal". GARCIA DE ENTERRÍA, Eduardo. Hacia una nueva justicia administrativa. $2^{\mathrm{a}}$ ed. ampliada. Madrid: Civitas, 1992, p. 44-45. 
Celso Antônio Bandeira de Mello destaca que o princípio da legalidade é um dos alicerces do sistema jurídico vigente em nosso país, determinante do modo de atuação da administração pública:

Certamente, esta integral subordinação da Administração à lei não é fórmula mágica, nem suficiente, só por só, para assegurar os objetivos que a nortearam. Contudo, certamente é condição importantíssima para que se realizem.

(...)

Pode ocorrer que o princípio em causa não desempenhe tão transcendente papel efetivo em outros sistemas jurídicos, mas no Direito brasileiro é, por sem dúvida, princípio de fulgurante importância. Cabe-lhe não apenas o caráter de preceito impositivo, mas também o de esteio para contenção de intemperanças estatais. Por isso, o conteúdo estimativo vazado nos preceitos constitucionais referidos ultrapassa até mesmo o rigor de suas claríssimas letras, para assumir a função de tônica do sistema, vetor axiológico que deve iluminar a análise e a inteligência de quaisquer regras editadas pelo Estado. ${ }^{92}$

Alejandro Huergo Lora, com base em Eberhard Schmidt-Aßmannn, destaca que não é qualquer órgão eleito que representa o povo. Mesmo sendo o ocupante do cargo executivo eleito pelo povo, sua função constitucional não é representar os interesses legislativos do povo, motivo pelo qual não pode avocar esta função, como segue:

A reserva de lei vem unida à legitimação democrática. Quer dizer: a necessidade de que determinadas decisões sejam adotadas pelo órgão que reúne os representantes democráticos dos cidadãos (até aqui a concordância é geral) para Schmidt-Aßmannn, a legitimação democrática não pertence a qualquer órgão 'eleito democraticamente', senão que o conceito constitucional de democracia se refere ao povo e ao órgão que o representa, quer dizer, o Parlamento. (...) O princípio democrático garante que as decisões democráticas sejam adotadas por um órgão que represente uma coletividade ampla e, sobretudo, determinada com fundamento em

${ }^{92}$ BANDEIRA DE MELLO, Celso Antônio. Curso de direito administrativo. $28^{\mathrm{a}}$ ed. São Paulo: Malheiros, 2011, p. 348-349. 
características gerais. Desta forma, se evita o predomínio de interesses setoriais, locais, de grupo, de classe, etc.. ${ }^{93}$ (tradução livre)

Especificamente no exercício da atividade sancionatória pelo Estado, entende-se que a punição depende do autoconsentimento. Cesare Beccaria, assim, define o princípio da estrita legalidade, não somente como alicerce do direito penal, mas também de toda a atividade sancionadora do Estado, que se exprime na máxima nullum crimen, nulla poena sine lege, como segue:

A primeira consequência desses princípios é que só as leis podem decretar sanções sobre os delitos, e que esta autoridade somente pode residir na pessoa do legislador, que representa toda a sociciedade unida pelo contrato social. Nenhum magistrado (que é parte da sociedade) pode com justiça impor uma pena em um outro membro da mesma sociedade. Mas um acréscimo além do limite estabelecido pela lei, que é a punição justa, constitui uma outra pena. Por consequência, um magistrado não pode, sob nenhum pretexto do zelo ou do bem público, aumentar a sanção estabelecida a um cidadão delinquente. ${ }^{94}$ (tradução livre)

Especificamente em relação às infrações e sanções administrativas, Marçal Justen Filho ensina que, "por terem configuração similar às de natureza penal,

\footnotetext{
${ }^{93}$ No original: "La reserva de Ley va unida a la legitimación democrática, es decir, a la necesidad de que determinadas decisiones sean adoptadas por el órgano que reúne a los representantes democráticos de los ciudadanos (hasta aquí, el acuerdo es general). Para SCHMIDT-AßMANNN, la legitimación democrática no la tiene cualquier órgano «elegido democráticamente», sino que el concepto constitucional de democracia se refiere al pueblo y al órgano que lo representa, es decir, el Parlamento. En un Estado federal, también tienen esa legitimación democrática 'los Parlamentos de los Estados federados (o Comunidades Autónomas). El principio democrático garantiza que las decisiones sean adoptadas por un órgano que represente a una colectividad amplia y, sobre todo, determinada con arreglo a características generales. De esta forma se evita el predominio de intereses sectoriales, locales, de grupo, de clase, etc..”. HUERGO LORA, Alejandro. Las sanciones administrativas. Madrid: Iustel, 2007, p. 375. Grifos no original.

${ }^{94}$ No original: "La prima conseguenza di questi principii è, che le sole Leggi possono decretar le pene su i delitti; e quest'autorità non può risedere che presso il Legislatore, che rappresenta tutta la società unita per un contratto sociale. Nessun magistrato (che è parte di società) può con giustizia infliggere pene contro ad un altro membro della società medesima. Ma una pena accresciuta al di là del limite fissato dalle leggi è la pena giusta, più un'altra pena; dunque non può un magistrato, sotto qualunque pretesto di zelo, o ben pubblico, accrescere la pena stabilita ad un delinquente cittadino". BECCARIA, Cesare. Dei Delitti e delle Pene. Milano: Francesco Sanvito, 1858, p. 11. Grifos no original.
} 
sujeitando-se a regime jurídico senão idêntico, ao menos semelhante" ${ }^{\text {"95 }}$, estão vinculadas à ideia de soberania popular, com o que concordamos, como segue:

A previsão da sanção em lei legitima democraticamente a punição, vinculando-a à soberania popular. Submeter a competência punitiva ao princípio da legalidade equivale a afirmar que somente o povo, como titular da soberania última, é quem se encarregará de qualificar certos atos como ilícitos e de escolher as sanções correspondentes e adequadas. ${ }^{96}$

Portanto, o autoconsentimento é o próprio núcleo do princípio da legalidade e razão pela qual a lei, editada por uma assembleia representativa, não pode ser substituída por atos administrativos editados por uma autoridade pública ou colegiado, senão em situações específicas.

\subsubsection{Função administrativa}

A partir da tripartição do Poder - tecnicamente denominada de tripartição de funções - e da titularidade do Poder pelo povo, os atos administrativos não podem ser designados como atos de poder perante os quais os administrados devem se submeter, como meros vassalos.

Pelo contrário, a Administração Pública é exercida em nome do titular do poder para execução dos comandos legais, de modo semelhante a um mandatário em relação ao outorgante. Sob fundamento e limitada pela lei ou pela Constituição, a autoridade não pode agir em seu próprio benefício ou ainda de modo arbitrário, mas apenas atender às finalidades legais ${ }^{97}$, como leciona Celso Antônio Bandeira de Mello:

A ordenação normativa propõe uma série de finalidades a serem alcançadas, as quais se apresentam, para quaisquer agentes estatais, como obrigatórias. A busca destas finalidades tem o caráter de dever (antes do que 'poder'), caracterizando uma função, em sentido jurídico.

\footnotetext{
${ }^{95}$ JUSTEN FILHO, Marçal. Curso de direito administrativo. $5^{\mathrm{a}}$ ed. São Paulo: Saraiva, 2010, p. 583.

96 JUSTEN FILHO, Marçal. Curso de direito administrativo. $5^{\mathrm{a}}$ ed. São Paulo: Saraiva, 2010, p. 583.

97 BANDEIRA DE MELLO, Celso Antônio. Curso de direito administrativo. $28^{\mathrm{a}}$ ed. São Paulo: Malheiros, 2011, p. 42-50.
} 
Em Direito, esta voz função quer designar um tipo de situação jurídica em que existe, previamente assinalada por um comando normativo, uma finalidade a cumprir e que deve ser obrigatoriamente atendida por alguém, mas no interesse de outrem, sendo que, este sujeito - o obrigado - para desincumbir-se de tal dever, necessita manejar poderes indispensáveis à satisfação do interesse alheio que está a seu cargo prover. Daí, uma distinção clara entre a função e a faculdade ou o direito que alguém exercita em seu prol. Na função o sujeito exercita um poder, porém o faz em proveito alheio, e o exercita não porque acaso queira ou não queira. Exercita-o porque é um dever. Então, pode-se perceber que o eixo metodológico do Direito Público não gira em torno da idéia de poder, mas gira em torno da idéia de dever. ${ }^{98}$

A ideia de poder-dever indica que a Administração somente pode atuar a fim de atender aos interesses públicos expressos em lei. Esta questão dos deveres-poderes será retomada no capítulo seguinte.

\subsubsection{Segurança jurídica: tipicidade}

Como afirma Flávio Bauer Novelli, o princípio da segurança jurídica "é também, ou é até mesmo em primeiro lugar, a segurança do direito enquanto pressuposto e fundamento" da Constituição. ${ }^{99}$ Assim, além de garantia da liberdade, é necessário que os destinatários das normas possam ter conhecimento de antemão das regras vigentes, de como antever as consequências jurídicas de seus atos.

Desta necessidade, surgem restrições à aplicação retroativa das normas, a necessidade de publicização dos textos legais e, especialmente no exercício da atividade sancionadora pelo Estado, a exigência da tipicidade. ${ }^{100}$

${ }^{98}$ BANDEIRA DE MELLO, Celso Antônio. Discricionariedade e controle jurisdicional. $2^{\mathrm{a}}$ ed., $9^{\mathrm{a}}$ tiragem. São Paulo: Malheiros, 2008, p. 13-14.

${ }^{99}$ NOVELLI, Flávio Bauer. Segurança dos Direitos Individuais e Tributação. Revista de Direito Tributário, n. 25/26, São Paulo, 1983, p. 164.

${ }^{100}$ Para o direito penal, especialmente após o grande acolhimento da teoria finalista de Hans Welzel, o dolo e a culpa passam a ser considerados elementos psicológicos que animam a conduta, ligando o agente ao seu fato. Como afirma Manoel Pedro Pimentel, "estes elementos, portanto, não são a causa da reprovabilidade da conduta, situando-se no terreno da tipicidade e não da culpabilidade" ( $O$ crime e a pena na atualidade. São Paulo: RT, 1983, p. 69). Sem entrar no mérito do debate entre as teorias causalistas e 
Alejandro Huergo Lora destaca a tipicidade como aspecto relevante do princípio da legalidade no exercício da atividade sancionadora pelo Estado:

O princípio da legalidade em matéria sancionadora tem um fundamento superior ao que pode ter com relação à atividade administrativa em geral. Por um lado, se trata de que as limitações à liberdade (sejam penas ou medidas não sancionadoras) procedam dos representantes dos cidadãos, o que supõe que o estabelecimento de infrações e sanções (mas também o de outras formas de intervenção administrativa) fique reservado à lei. Mas o princípio da legalidade sancionadora também inclui um mandato de certeza (Bestimmheitsgebot), de acordo com o qual a tipificação das infrações e das sanções (mas sobretudo das primeiras) deve ser feita com maior grau possível de precisão, a fim de que se cumpra a finalidade da norma sancionadora, quer dizer, indicar ao cidadão, com a maior claridade possível, qual é a conduta que deve evitar para que não lhe seja imposta a sanção prevista pela norma. $^{101}$ (tradução livre)

\section{Neste mesmo sentido, leciona Alejandro Nieto:}

A suficiência da tipificação é, em definitivo, uma exigência da segurança jurídica e se concretiza, já que não na certeza absoluta, na previsão razoável das consequências jurídicas da conduta. Diante da norma, o cidadão deve saber que sua conduta constitui uma infração e, além disso, conhecer qual é a resposta punitiva que o ordenamento impõe a tal infração. Ou, dito com outras palavras: a tipificação é suficiente quando consta na norma uma predeterminação inteligível da infração, da sanção e da correlação entre uma e outra (...). ${ }^{102}$ (tradução livre)

\footnotetext{
finalistas, considerando os limites do presente trabalho, apenas por questão de método, o conceito de tipicidade será limitado à ideia de que a norma que define a conduta como infração deva apresentar a descrição completa da conduta, mediante indicação de todos os elementos necessários para tanto.

${ }^{101}$ No original: "El principio de legalidad tiene en materia sancionadora un fundamento superior al que puede tener respecto a la actividad administrativa en general. Por un lado, se trata de que las limitaciones a lalibertad (sean penas o medidas no sancionadoras) procedan de los representantes de los ciudadanos, lo que supone que el establecimiento de infracciones y sanciones (pero también el de otras formas de intervención administrativa) quede reservado a la Ley. Pero el principio, de legalidad sancionadora también incluye un mandato de certidumbre (Bestimmheitsgebot), de acuerdo con el cual la tipificación de las infracciones y de las sanciones (pero sobre todo de las primeras) debe hacerse con el mayor grado posible de precisión, a fin de que se cumpla la finalidad de la norma sancionadora, es decir, indicarle al ciudadano, con la mayor claridad posible, cuál es la conducta que debe evitar para que no se le imponga la sanción prevista por la norma". HUERGO LORA, Alejandro. Las sanciones administrativas. Madrid: Iustel, 2007, p. 366.

${ }^{102}$ No original: "La suficiencia de la tipificación es, en definitiva, una exigencia de la seguridad jurídica y se concreta, ya que no en la certeza absoluta, en la predicción razonable de las consecuencias jurídicas de la conducta. A la vista de la norma debe saber el ciudadano que su conducta constituye una infracción y,
} 
O princípio da tipicidade significa que a lei que institui a sanção administrativa deve indicar expressamente os elementos necessários para a identificação do fato real correspondente à hipótese de infração administrativa e sua respectiva sanção, de modo a garantir a segurança jurídica dos administrados. Nesse sentido, sustenta Heraldo Garcia Vitta:

De fato, os princípios da segurança jurídica e o da boa-fé obrigam o Estado a atuar sem surpresas, determinando, taxativamente, por meio de lei prévia, os comportamentos, contrários ao Direito. Somente desse modo estar-se-á cumprindo os ditames do regime democrático de Direito.

Pouco valeria o princípio da legalidade se o administrador pudesse impor penalidades administrativas sem que houvessem sido definidos, com antecedência e de maneira exaustiva, os comportamentos que são pressupostos das sanções. Do mesmo modo, o referido princípio seria inócuo se, acaso, o administrador pudesse determinar as infrações por atos subalternos da lei, ficando ao Legislativo, apenas, a enumeração das respectivas penalidades. ${ }^{103}$

Alexandro Nieto destaca que não existe um único entendimento sobre o nível de detalhamento necessário em lei para que seja satisfeito o princípio da tipicidade e compara a exigência feita na Alemanha de grau máximo enquanto na Espanha se admite o nível de razoabilidade, como segue:

A descrição rigorosa e perfeita da infração é, salvo exceções, praticamente impossível. O detalhamento do tipo tem seu limite. As exigências maximalistas só conduzem, portanto, à paralisia normativa ou à nulidade de boa parte das disposições sancionadoras existentes ou por editar-se. Neste ponto, que a doutrina alemã se contenta, como já sabemos, com a simples exigência 'da maior precisão possível', que é o que também nós espanhóis devemos pretender. Ainda que, entre nós e segundo acabamos de ver, a forma mais generalizada é a da descrição suficiente. Com a suficiência se indica que já se chegou, que o intérprete pode se dar por satisfeito. A expressão 'da maior precisão possível' se dirige melhor ao

además, conocer cuál es la respuesta punitiva que a tal infracción depara el Ordenamiento. O dicho con otras palabras: la tipificación es suficiente cuando consta en la norma una predeterminación inteligible de la infracción, de la sanción y de la correlación entre una y otra (como ha sido recogido en la STS de 11 de junio de 2000, ya citada)". NIETO, Alejandro. Derecho administrativo sancionador. $4^{\mathrm{a}}$ ed. ampliada, $2^{\mathrm{a}}$ reimpressão. Madrid: Tecnos, 2008, p. 305.

${ }^{103}$ VITTA, Heraldo Garcia. A sanção no direito administrativo. São Paulo: Malheiros, 2003, p. 91. 
legislador como um incentivo para que aperfeiçoe e arremate sua obra. ${ }^{104}$ (tradução livre)

Assim, o princípio da legalidade, especificamente para o exercício da atividade sancionadora, exige que as normas sejam efetivamente editadas por uma assembleia representativa e que exerça esta função na melhor medida possível sem a edição de normas vagas e imprecisas que consistam em atribuição genérica de poderes ao aplicador da norma, o que consistiria em verdadeira delegação de suas atribuições e, portanto, esvaziamento do próprio sentido do princípio da legalidade.

Isso não significa que todas as leis gozem de uma "clareza e segurança jurídicas absolutas através de normas rigorosamente elaboradas", ${ }^{105}$ de forma a garantir a univocidade a todos os atos administrativos. O Legislativo tem como limites a própria generalidade e abstração das normas editadas, o que é um impedimento para o próprio tratamento da matéria de modo minucioso a ponto de exaurir todas as possibilidades da sua aplicação. Entretanto, considerando que a eleição das hipóteses de infração administrativa constitui uma escolha legislativa, não cabe à administração proceder à integração e à eventual correção da norma legal.

Cabe então retomar a distinção entre o processo de interpretação e o processo de desenvolvimento do direito. Com base em Arthur Meier-Hayoz, Karl Larenz leciona que o primeiro é um processo de entendimento da norma limitado aos diferentes significados que podem advir da leitura da linguagem utilizada pelo legislador, como segue:

\footnotetext{
${ }^{104}$ No original: "La descripción rigurosa y perfecta de la infracción es, salvo excepciones, prácticamente imposible. El detallismo del tipo tiene su límite. Las exigencias maximalisras sólo conducen, por tanto, a la parálisis normativa o a la nulidad de buena parte de las disposiciones sancionadoras existentes o por dictar. De aquí que la doctrina alemana se contente, como ya sabemos, con la simple exigencia de «la mayor precisión posible», que es lo que también los españoles debemos pretender. Aunque, entre nosotros y según acabamos de ver, la fórmula más generalizada es la de la descripción suficiente. Con la suficiencia se indica que ya se ha llegado, que el intérprete ya puede darse por satisfecho. La consigna de «la mayor precisión posible» se dirige, más bien, al legislador como un acicate para que perfeccione y remate su obra." NIETO, Alejandro. Derecho administrativo sancionador. $4^{\mathrm{a}}$ ed. ampliada, $2^{\mathrm{a}}$ reimpressão. Madrid: Tecnos, 2008, p. 305.

${ }^{105}$ ENGISCH, Karl. Introdução ao pensamento jurídico. $9^{\mathrm{a}}$ ed. Lisboa: Fundação Calouste Gulbenkian, 2004, p. 206.
} 
O sentido literal, portanto, teria uma dupla função: ele é o ponto de partida para a investigação jurisprudencial do sentido e demarca, ao mesmo tempo, as fronteiras da atividade interpretativa. $\mathrm{O}$ juiz deve partir do sentido literal e, por meio do sentido literal, é delimitado o campo em que a interpretação poderá se dar.

Esse posicionamento pode ser considerado majoritário. O que não é de se admirar. A tese da prioridade relativa do sentido literal harmoniza-se com o posicionamento livre de formalismos do ZGB acerca da atividade jurisdicional e harmoniza-se com a sua forma de expressão simples, incompatível com uma aderência estrita ao sentido literal. ${ }^{106}$ (tradução livre)

Para a interpretação, Karl Larenz apresenta os critérios a seguir, que devem ser utilizados sucessivamente: (i) o contexto significativo da lei; (ii) a intenção reguladora, fins e ideias normativas do legislador histórico; (iii) os critérios teleológicoobjetivos; e (iv) o preceito de interpretação conforme a Constituição. ${ }^{107}$

Já o desenvolvimento do direito extrapola os limites do possível sentido da norma para inovar no mundo jurídico, seja mediante preenchimento de lacunas (desenvolvimento do direito imanente à lei) ou pelo "desenvolvimento do direito para além do plano da lei". ${ }^{108}$

Diante deste quadro, em alguns casos não há que falar em preenchimento de lacuna da norma. São as situações em face das quais o legislador se mantém em silêncio por opção de política legislativa, configurando o denominado "silêncio eloquente".

\footnotetext{
${ }^{106}$ No original: "Der Wortlaut hat danach eine doppelte Aufgabe: Er ist Ausgangspunkt für die richterliche Sinnermittlung und steckt zugleich die Grenzen seiner Auslegungstätigkeit ab. Vom Wortlaut hat der Richter auszugehen und durch den Wortlaut wird ihm der Raum abgegrenzt, innerhalb dessen seine Auslegung sich bewegen muss. Diese Richtung kann als herrschend bezeichnet werden. Das ist nicht verwunderlich. Die Ansicht von der relativen Priorität des Wortlautes steht im Einklang mit der im ZGB zum Ausdruck kommenden, von formalismus freien Auffassung der richterlichen Tätigkeit und mit seiner leicht verständlichen Ausdrucksweise, die für ein strenges Festhalten am Worlaut ungeeignet ware”. MEIERHAYOZ, Arthur. Der Richter als Gesetzgeber, eine Besinnung auf die von den Gerichten befolgten Verfahrensgrundsätze im Beriche, der freien richterlichen Rechtsfindung gemäss Art. 1 Abs. 2 des schweizerischen Zivilgesetzbuches. Zurique: Juris-Verlag, 1951, p. 42-43.

${ }^{107}$ LARENZ, Karl. Metodologia da ciência do direito. $3^{\text {a }}$ ed. Lisboa: Fundação Calouste Gulbenkian, 1997, p. $439-484$.

${ }^{108}$ LARENZ, Karl. Metodologia da ciência do direito. $3^{\mathrm{a}}$ ed. Lisboa: Fundação Calouste Gulbenkian, 1997, p. 519-574.
} 
No âmbito do poder sancionatório do Estado, o silêncio eloquente implica na inexistência de hipótese de sanção e na impossibilidade de subsunção de qualquer fato a normas sancionadoras, o que torna esse mesmo fato atípico. Não pode a Administração, por sua vez, utilizar-se de métodos de integração e de desenvolvimento do direito para ampliar o alcance ou dar sentido distinto a outra norma para atingir determinada conduta, na qual o legislador entendeu por bem não intervir.

Igualmente é vedada à Administração, no exercício da função sancionatória, a correção das chamadas leis defeituosas. Para Larenz apenas é possível identificar uma falha na lei "na medida em que se pergunta se a lei é incompleta comparada com a sua própria intenção reguladora ou se somente a decisão nela tomada não resiste a uma crítica de política legislativa". ${ }^{109}$ Para esses casos o autor indica ser necessário um desenvolvimento do direito que ultrapassa a lei, prática esta que consiste em inovação no mundo jurídico, também incompatível com o restrito poder regulamentar da Administração Pública.

Quanto à impossibilidade de integração normativa para imposição de sanções administrativas àqueles fatos atípicos, portanto indiferentes ao poder sancionatório do Estado, cabe trazer a seguinte afirmação de Lúcia Valle Figueiredo:

Entretanto, para criar obrigações, para compelir alguém, por exemplo, a recolher tributo ou criar sanções administrativas, não poderá ser feita integração normativa, por falta de tipicidade, porque este é um dos princípios, da certeza jurídica quanto à lei vigente, princípio, este, que conduz à segurança jurídica. ${ }^{110}$

Portanto, em matéria de imposição de sanções, é exigência do princípio da legalidade que os elementos da infração estejam suficientemente previstos em lei, do mesmo modo que a sanção, sendo vedada à administração a criação de novos tipos, mesmo

\footnotetext{
${ }^{109}$ LARENZ, Karl. Metodologia da ciência do direito. $3^{\mathrm{a}}$ ed. Lisboa: Fundação Calouste Gulbenkian, 1997, p. $530-531$.

${ }^{110}$ FIGUEIREDO, Lúcia Valle. Curso de direito administrativo. $8^{\mathrm{a}}$ ed. São Paulo: Malheiros, 2006, p. 447448.
} 
mediante lei que contenha termos de grande generalidade para delegação oblíqua da função legislativa, tema que abordaremos no item 2.5.

\subsection{Delegação legislativa}

Carlos Roberto de Siqueira Castro conceitua delegação legislativa como "transferência da função normativa atribuída originária e constitucionalmente ao Poder Legislativo a órgãos ou agentes especializados do próprio Legislativo ou integrantes dos demais Poderes do Estado". ${ }^{111}$ Ocorre a transferência da competência legiferante, de edição de norma jurídica, entendida como "regra de conduta criadora ou modificadora do direito dito objetivo e dotada de estatalidade, isto é, positivada e/ou suscetível de aplicação pelo Estado"112, a um órgão ou agente estatal, denominado delegado, que não detinha esta atribuição para exercer esta competência, pelo "esquema de partilha de competências orgânicas traçado pela Constituição" ${ }^{113}$, se não houvesse a delegação.

A delegação para o próprio Legislativo, segundo Siqueira Castro, consiste em "uma simples especialização de parcela do órgão parlamentar para exercício da atividade legiferante". ${ }^{114}$ O delegado, no caso, pode ser qualquer uma das casas ou ainda comissão parlamentar.

Delegação legislativa não é sinônimo de delegação de poderes, mas apenas uma espécie da qual o segundo é o gênero. A delegação de poderes pode ocorrer também mediante transferência de funções judiciárias ou executivas. Neste último caso, podemos dar como exemplo a fixação de políticas públicas pelo Judiciário.

\footnotetext{
${ }^{111}$ CASTRO, Carlos Roberto Siqueira. O Congresso e as delegações legislativas. Rio de Janeiro: Forense, 1986 , p. 81.

112 CASTRO, Carlos Roberto Siqueira. O Congresso e as delegações legislativas. Rio de Janeiro: Forense, 1986, p. 81 .

${ }^{113}$ CASTRO, Carlos Roberto Siqueira. O Congresso e as delegações legislativas. Rio de Janeiro: Forense, 1986, p. 82.

${ }^{114}$ CASTRO, Carlos Roberto Siqueira. O Congresso e as delegações legislativas. Rio de Janeiro: Forense, 1986, p. 83.
} 
Manoel Gonçalves Ferreira Filho aponta que a delegação legislativa é própria do parlamentarismo, em que "elaborada pelo Gabinete, aprovada por este, a lei exprime também a vontade da maioria parlamentar, embora indiretamente, já que o Gabinete é fruto desta e está em dependência". ${ }^{115}$ Por outro lado, no presidencialismo "não está na dependência do Congresso nem exprime, necessariamente, a sua maioria"116, de modo que "opera uma concentração de poderes" 117 nas mãos do presidente "que o fortalece sobremodo, sem que isso seja de alguma forma compensado pelo desenvolvimento de qualquer controle novo". 118

Siqueira Castro propõe a distinção entre a delegação legislativa nominada, como é o caso da prevista expressamente no artigo 68 da Constituição Federal $^{119}$, e a inominada, sem expressa previsão constitucional, fundada em norma infraconstitucional, como segue:

Diversamente, a delegação do tipo inominada compreende as variadas experiências de atribuição de função normativa sem nomeação constitucional, e que costumeiramente se perfazem no curso da estruturação de determinado órgão da Administração direta ou indireta, materialmente normativa para disciplinar, na mais das vezes por via de resolução ou instrução normativa, o setor ou a atividade abrangida pelo serviço público assim descentralizado. ${ }^{120}$

Manoel Gonçalves Ferreira Filho faz igual distinção denominando de legiferação consentida aquela delegada pelo titular do poder de legislar, o Poder

\footnotetext{
${ }^{115}$ FERREIRA FILHO, Manoel Gonçalves. Curso de direito constitucional. 36 ${ }^{\mathrm{a}}$ ed. São Paulo: Saraiva, 2010, p. 231.

${ }^{116}$ FERREIRA FILHO, Manoel Gonçalves. Curso de direito constitucional. $36^{\mathrm{a}}$ ed. São Paulo: Saraiva, 2010, p. 231.

${ }^{117}$ FERREIRA FILHO, Manoel Gonçalves. Curso de direito constitucional. 36a ed. São Paulo: Saraiva, 2010, p. 231.

${ }^{118}$ FERREIRA FILHO, Manoel Gonçalves. Curso de direito constitucional. 36a ed. São Paulo: Saraiva, 2010, p. 231.

119 “Art. 68. As leis delegadas serão elaboradas pelo Presidente da República, que deverá solicitar a delegação ao Congresso Nacional."

${ }^{120}$ CASTRO, Carlos Roberto Siqueira. O Congresso e as delegações legislativas. Rio de Janeiro: Forense, 1986, p. 96. Grifos no original.
} 
Legislativo, e legiferação permitida, quando há atribuição expressa na Constituição, inexistindo propriamente uma delegação no segundo caso. ${ }^{121}$

Segundo Siqueira Castro, as delegações por norma infraconstitucional podem ser os regulamentos de execução, regulamentos de complementação e os regulamentos autônomos.

Os regulamentos de execução destinam-se a detalhar o conteúdo da lei, a fim de disciplinar a matéria nos seus pormenores "não rompendo com a tradição clássica da supremacia da vontade parlamentar que, segundo os melhores exemplos da representação política, consiste na afirmação da vontade do povo através das Câmaras regularmente eleitas". ${ }^{122}$

(...) sempre que um regulamento sobre matéria já disciplinada em lei, depara-se-nos o problema da perfeita adequação do regulamento ao texto da lei. E isso porque, sendo o regulamento uma simples particularização ou desenvolvimento da lei, a cujo espírito deve incondicional obediência, será ilegal e, portanto, inaplicável a disposição regulamentar que se puser em oposição ao comando do Legislativo, seja por contradizê-lo, seja por alargar ou reduzir o âmbito de suas palavras. ${ }^{123}$

O regulamento de execução, portanto, encontra seus limites determinados pelos mesmos limites da possível interpretação do texto legal regulamentado, sendo vedado ultrapassar o possível significado dos termos utilizados pelo legislador.

Já os regulamentos de complementação ultrapassam os limites da interpretação, na busca de complementar matéria diante da qual o legislador foi omisso, aditando "complementos aos princípios e diretrizes contidos nas normas gerais fixadas pelo Parlamento, a que os publicistas franceses designam de lois-cadres, e que surgiram na França

\footnotetext{
${ }^{121}$ FERREIRA FILHO, Manoel Gonçalves. Princípios fundamentais de direito constitucional. $2^{\mathrm{a}}$ ed. São Paulo: Saraiva, 2010, p. 189.

122 CASTRO, Carlos Roberto Siqueira. O Congresso e as delegações legislativas. Rio de Janeiro: Forense, 1986, p. 118.

${ }^{123}$ DANTAS, F. C. de San Tiago. Problemas de direito positivo. Rio de Janeiro: Forense, 1953, p. 207.
} 
com a lei de 17 de agosto de 1948". ${ }^{124}$ Siqueira Castro exemplifica com o art. 11 da Constituição de 1937, que limitava a competência do Legislativo à elaboração de princípios gerais. $^{125}$

Os regulamentos autônomos são os atos administrativos normativos incondicionados "à lei ordinária, [pelos quais] o governo edita normas com arrimo na reserva regulamentar autônoma prevista expressa ou implicitamente em algumas constituições da atualidade e que expressam genuíno poder legislativo governamental". ${ }^{26}$

Maria Sylvia Zanella Di Pietro classifica os regulamentos em dois grupos: o regulamento executivo e o regulamento independente ou autônomo ${ }^{127}$, que acaba por abranger também o conceito de regulamento de complementação proposto por Siqueira Castro.

A delegação legislativa, por si só, não implica necessariamente no esvaziamento da representatividade do parlamento e, portanto, em um regime autoritário com concentração dos poderes na pessoa do Chefe do Poder Executivo, típico das ditaduras fascistas. Mesmo em países democráticos pode existir essa figura, como leciona Caio Tácito, a partir das decisões do Conselho de Estado da França:

Não é inconstitucional, mesmo nos países contrários à delegação de poderes, a participação do Executivo na criação do direito objetivo. Regulamentar não é somente reproduzir analiticamente a lei, mas ampliá-la e completá-la, segundo seu espírito e seu conteúdo, sobretudo nos aspectos que a própria lei, expressa ou implicitamente, outorga à esfera regulamentar. ${ }^{128}$

\footnotetext{
${ }^{124}$ CASTRO, Carlos Roberto Siqueira. O Congresso e as delegações legislativas. Rio de Janeiro: Forense, 1986, p. 120. Grifos no original.

125 “Art 11 - A lei, quando de iniciativa do Parlamento, limitar-se-á a regular, de modo geral, dispondo apenas sobre a substância e os princípios, a matéria que constitui o seu objeto. O Poder Executivo expedirá os regulamentos, complementares."

${ }^{126}$ CASTRO, Carlos Roberto Siqueira. O Congresso e as delegações legislativas. Rio de Janeiro: Forense, 1986, p. 121. Grifos no original.

${ }^{127}$ DI PIETRO, Maria Sylvia Zanella. Parcerias na administração pública. $7^{\text {a }}$ ed. São Paulo: Atlas, 2009, p. 191.

${ }^{128}$ TÁCITO, Caio. As Delegações Legislativas e o Poder Regulamentar. Revista de Direito Administrativo, n. 34, Rio de Janeiro, FGV, outubro a dezembro de 1953.
} 
Maria Sylvia Zanella Di Pietro aponta que, nesses países em que se admite o decreto autônomo, utiliza-se uma distinção originária do direito alemão entre regulamentos jurídicos ou normativos e regulamentos administrativos ou de organização. Os primeiros gozam de menos discricionariedade da Administração, pois "estabelecem normas sobre supremacia geral, ou seja, aquelas relações que ligam todos os cidadãos ao Estado, tal como ocorre com as normas inseridas no poder de polícia, limitadoras dos direitos individuais em benefício do interesse público". ${ }^{129}$ Já os últimos destinam-se a regular situações de sujeição especial, com maior discricionariedade, mas vinculados "a um título jurídico emitido pela própria Administração, dizendo respeito à própria organização administrativa ou forma de prestação do serviço". 130

Cabe destacar também a impossibilidade de se estabelecer um critério absoluto a priori para identificar quando há um caso de regulamento de execução, de complementação ou autônomo. Embora a diferenciação entre interpretação e desenvolvimento, como já apresentado, seja uma importante ferramenta, pode haver a delegação, por via oblíqua, mediante uso de termos de grande generalidade, que acabam por se mostrarem vagos e imprecisos, e, ao permitir um demasiado campo para a interpretação, deixa a verdadeira escolha do conteúdo da norma ao regulamentador. Neste sentido, afirma Vitor Nunes Leal:

Em regime de delegação proibida, as dificuldades aumentam: embora o regulamento esteja estritamente conforme a lei, pode a lei conter alguma disposição muito genérica, vaga ou omissa, que equivalha a uma delegação, e que o regulamento concretizou, esclareceu ou completou, violando, assim, a proibição constitucional das delegações legislativas.

\section{(...)}

Seria impossível estabelecer a priori um critério capaz de solucionar as dúvidas. O regulamento, dado o seu papel de texto complementar da lei, envolve sempre a

\footnotetext{
${ }^{129}$ DI PIETRO, Maria Sylvia Zanella. Parcerias na administração pública. $7^{\mathrm{a}}$ ed. São Paulo: Atlas, 2009, p. 191.

${ }^{130}$ DI PIETRO, Maria Sylvia Zanella. Parcerias na administração pública. $7^{\mathrm{a}}$ ed. São Paulo: Atlas, 2009, p. 191.
} 
idéia de lacuna legislativa, o que equivale a dizer que contém sempre certo resíduo legislativo, certa medida de autoridade delegada. ${ }^{131}$

Marçal Justen Filho alerta que, embora a delegação legislativa não seja incompatível com a democracia, é um instituto próprio de regimes parlamentaristas, nos quais o controle dos atos do executivo pelo parlamento é amplo, até mesmo mediante a destituição do gabinete:

Os Estados parlamentaristas reconhecem ao governo competências normativas muito mais intensas do que se passa em Estados presidencialistas. Isso decorre do fato de que o parlamentarismo propicia uma participação muito intensa do Legislativo na estrutura do Poder Executivo. Admite-se que o primeiro-ministro ou o conselho de ministros produzam normas que, em tese, dependeriam de lei. Mas os ministros são indicados pela maioria parlamentar, que disporia de condições para produzir a aprovação de leis. Em outras palavras, a produção normativa do Poder Executivo encontra-se sob controle do Poder Legislativo.

O Brasil não consagra o regime parlamentarista, mas o presidencialista. Isso impede a implementação de certas práticas cuja origem repousa na concepção de que o exercente da chefia do Executivo depende da aprovação do Parlamento e a execução de providências ofensivas às concepções prevalentes no âmbito do Legislativo autorizaria a remoção do governante. ${ }^{132}$

Marçal Justen Filho apresenta como exemplo o "instituto da deslegalização", que vem sendo adotado na Itália, que "consiste na transferência por meio de lei, de competência normativa primária para a Administração Pública". ${ }^{133}$ Esta, afirma o autor, "pode ser apropriada a regimes parlamentaristas", mas "sua admissão num regime presidencialista depende da adoção de instrumentos de controle legislativo mais eficientes". ${ }^{134}$

Portanto, a atividade legislativa em geral atribui um certo poder de regulamentar ao Executivo que pode ser expresso ou tácito, limitado ao sentido do texto da lei

${ }^{131}$ LEAL, Vítor Nunes. Delegações Legislativas. Revista de Direito Administrativo, volume V, Rio de Janeiro, FGV, julho de 1946, p. 384.

132 JUSTEN FILHO, Marçal. Curso de direito administrativo. $5^{\text {a }}$ ed. São Paulo: Saraiva, 2010, p. 583.

${ }^{133}$ JUSTEN FILHO, Marçal. Curso de direito administrativo. $5^{\mathrm{a}}$ ed. São Paulo: Saraiva, 2010, p. 160.

${ }^{134}$ JUSTEN FILHO, Marçal. Curso de direito administrativo. $5^{\text {a }}$ ed. São Paulo: Saraiva, 2010, p. 160. 
ou amplo, e que pode variar também em razão da precisão ou da vagueza dos termos utilizados pelo legislador.

Embora seja encontrada delegação legislativa em países democráticos, sua ampla utilização em regimes presidencialistas é um instrumento para esvaziamento das funções do Legislativo, como ocorreu no Brasil durante o Estado Novo, por exemplo. A seguir, trataremos da compatibilidade de decretos delegados e autônomos com o regime instituído pela Constituição Federal de 1988.

\subsection{Princípio da legalidade na Constituição de 1988}

Na Constituição de 1988, o princípio da legalidade é declarado em vários dispositivos, seja em caráter geral (art. $5^{\circ}$, II) e na sua aplicação em matérias específicas, como no direito penal e sancionatório (art. $5^{\circ}$, XXXIX), administrativo (art. 37, caput), tributário (art. 150, I), como segue:

Art. $5^{\circ}$ Todos são iguais perante a lei, sem distinção de qualquer natureza, garantindo-se aos brasileiros e aos estrangeiros residentes no País a inviolabilidade do direito à vida, à liberdade, à igualdade, à segurança e à propriedade, nos termos seguintes:

(...)

II - ninguém será obrigado a fazer ou deixar de fazer alguma coisa senão em virtude de lei;

$[\ldots]$

XXXIX - não há crime sem lei anterior que o defina, nem pena sem prévia cominação legal.

Art. 37. A administração pública direta e indireta de qualquer dos Poderes da União, dos Estados, do Distrito Federal e dos Municípios obedecerá aos princípios de legalidade, impessoalidade, moralidade, publicidade e eficiência e, também, ao seguinte: [...]. 
O exercício da atividade legislativa de todas as matérias de competência da União Federal é atribuído ao Congresso Nacional, como dispõe o art. 48:

Art. 48. Cabe ao Congresso Nacional, com a sanção do Presidente da República, não exigida esta para o especificado nos arts. 49, 51 e 52, dispor sobre todas as matérias de competência da União, especialmente sobre: (...).

Por outro lado, a Constituição atribui ao Executivo a sanção de leis (pelo Presidente da República) e a edição de normas infralegais que têm por finalidade o detalhamento da lei para sua fiel execução, como se verifica a seguir:

Art. 84. Compete privativamente ao Presidente da República:

(...)

IV - sancionar, promulgar e fazer publicar as leis, bem como expedir decretos e regulamentos para sua fiel execução;

(...)

VI - dispor, mediante decreto, sobre:

a) organização e funcionamento da administração federal, quando não implicar aumento de despesa nem criação ou extinção de órgãos públicos;

b) extinção de funções ou cargos públicos, quando vagos.

Não consta na Constituição a atribuição expressa ao Poder Executivo da função legislativa suplementar à legislação. Nos pontos em que: (i) não houver legislação sobre a matéria ou (ii) a lei emanada do parlamento for omissa ou (iii) imprecisa, não cabe ao Executivo avocar a si a competência legislativa. Pelo contrário, o art. 84, inciso IV, determina que decretos e regulamentos têm uma função limitada à edição de normas para detalhamento do conteúdo da lei de modo a propiciar a sua "fiel execução". Este detalhamento consiste na compreensão $^{135}$ do conteúdo da lei e na elaboração de normas de caráter subordinado, dentro dos limites do processo de interpretação, com o especial propósito de propiciar, na medida do possível, a uniformização de procedimentos da Administração.

135 Como apresentamos nos itens 1.2 e 1.3, adotamos o entendimento de Karl Larenz, para quem a compreensão de um texto normativo é o início do processo de interpretação, que consiste na construção da norma com a utilização de outros elementos. 
A Constituição Federal prevê que determinadas matérias específicas, típicas de lei, podem ser objeto de decreto presidencial. Podemos citar, como exemplo, a alteração das alíquotas de determinados impostos que têm função extrafiscal (além de permitirem o ingresso de receita pública têm função de regulação da economia), como os que incidem sobre importação, exportação, produtos industrializados e operações financeiras e câmbio:

Art. 150. Sem prejuízo de outras garantias asseguradas ao contribuinte, é vedado à União, aos Estados, ao Distrito Federal e aos Municípios:

I - exigir ou aumentar tributo sem lei que o estabeleça;

(...)

Art. 153. Compete à União instituir impostos sobre:

I - importação de produtos estrangeiros;

II - exportação, para o exterior, de produtos nacionais ou nacionalizados;

(...)

IV - produtos industrializados;

V - operações de crédito, câmbio e seguro, ou relativas a títulos ou valores mobiliários;

$\S 1^{\circ}$ - É facultado ao Poder Executivo, atendidas as condições e os limites estabelecidos em lei, alterar as alíquotas dos impostos enumerados nos incisos I, II, IV e V.

A delegação legislativa só é permitida quando expressamente prevista na Constituição Federal de 1988. Os artigos 59 e 68 determinam que, mediante solicitação do Presidente, ela deve ser autorizada pelo Congresso Nacional mediante resolução que deverá indicar o conteúdo e os termos de seu exercício, ou, como leciona Manoel Gonçalves Ferreira Filho, "deverá ser indicada a matéria sobre a qual deverá versar a lei delegada e o prazo durante o qual será lícito ao Presidente editar normas sobre essa matéria”" ${ }^{36}$, como segue:

Art. 59. O processo legislativo compreende a elaboração de:

${ }^{136}$ FERREIRA FILHO, Manoel Gonçalves. Curso de direito constitucional. 36 ${ }^{\mathrm{a}}$ ed. São Paulo: Saraiva, 2010, p. 233. 
IV - leis delegadas;

$(\ldots)$

Art. 68. As leis delegadas serão elaboradas pelo Presidente da República, que deverá solicitar a delegação ao Congresso Nacional.

$\S 1^{\circ}$ - Não serão objeto de delegação os atos de competência exclusiva do Congresso Nacional, os de competência privativa da Câmara dos Deputados ou do Senado Federal, a matéria reservada à lei complementar, nem a legislação sobre:

I - organização do Poder Judiciário e do Ministério Público, a carreira e a garantia de seus membros;

II - nacionalidade, cidadania, direitos individuais, políticos e eleitorais;

III - planos plurianuais, diretrizes orçamentárias e orçamentos.

$\S 2^{\circ}$ - A delegação ao Presidente da República terá a forma de resolução do Congresso Nacional, que especificará seu conteúdo e os termos de seu exercício.

$\S 3^{\text {o }}$ - Se a resolução determinar a apreciação do projeto pelo Congresso Nacional, este a fará em votação única, vedada qualquer emenda.

Diogo de Figueiredo Moreira Neto ${ }^{137}$ destaca que a delegação legislativa somente é possível mediante lei delegada, pois afora é implicitamente vedada pelo princípio da separação dos poderes, este que não pode ser alterado sequer por emenda constitucional, consoante art. $60, \S 4^{\circ}$, III, da Constituição Federal ${ }^{138}$.

Além da lei delegada, também é atribuído ao Presidente da República o exercício da função legislativa mediante edição de medidas provisórias, "as quais, no entanto, para serem legítimas, hão de atender a pressupostos formais, materiais e, ainda, a regra de

\footnotetext{
${ }^{137}$ MOREIRA NETO, Diogo de Figueiredo. Curso de direito administrativo. $15^{\mathrm{a}}$ ed. Rio de Janeiro: Forense, 2009 , p. 32.

138 "§ $4^{\circ}$ - Não será objeto de deliberação a proposta de emenda tendente a abolir: (...) III - a separação dos Poderes;"
} 
procedimento que agora se exigem no art. 62 da CF com o enunciado oferecido pela EC32/2001"139:

Art. 62. Em caso de relevância e urgência, o Presidente da República poderá adotar medidas provisórias, com força de lei, devendo submetê-las de imediato ao Congresso Nacional.

$(\ldots)$

$\S 3^{\circ}$ As medidas provisórias, ressalvado o disposto nos $\S \S 11$ e 12 perderão eficácia, desde a edição, se não forem convertidas em lei no prazo de sessenta dias, prorrogável, nos termos do $\S 7^{\circ}$, uma vez por igual período, devendo o Congresso Nacional disciplinar, por decreto legislativo, as relações jurídicas delas decorrentes.

$\S 4^{\circ} \mathrm{O}$ prazo a que se refere o $\S 3^{\circ}$ contar-se-á da publicação da medida provisória, suspendendo-se durante os períodos de recesso do Congresso Nacional.

$\S 5^{\circ}$ A deliberação de cada uma das Casas do Congresso Nacional sobre o mérito das medidas provisórias dependerá de juízo prévio sobre o atendimento de seus pressupostos constitucionais.

$\S 6^{\circ}$ Se a medida provisória não for apreciada em até quarenta e cinco dias contados de sua publicação, entrará em regime de urgência, subseqüentemente, em cada uma das Casas do Congresso Nacional, ficando sobrestadas, até que se ultime a votação, todas as demais deliberações legislativas da Casa em que estiver tramitando.

$\S 7^{\circ}$ Prorrogar-se-á uma única vez por igual período a vigência de medida provisória que, no prazo de sessenta dias, contado de sua publicação, não tiver a sua votação encerrada nas duas Casas do Congresso Nacional.

$\S 8^{\circ}$ As medidas provisórias terão sua votação iniciada na Câmara dos Deputados.

$\S 9^{\circ}$ Caberá à comissão mista de Deputados e Senadores examinar as medidas provisórias e sobre elas emitir parecer, antes de serem apreciadas,

${ }^{139}$ SILVA, José Afonso da. Curso de direito constitucional positivo. $28^{\mathrm{a}}$ ed. São Paulo: Malheiros, 2007, p. 526. 
em sessão separada, pelo plenário de cada uma das Casas do Congresso Nacional.

$\S$ 10. É vedada a reedição, na mesma sessão legislativa, de medida provisória que tenha sido rejeitada ou que tenha perdido sua eficácia por decurso de prazo.

$\S 11$. Não editado o decreto legislativo a que se refere o $\S 3^{\circ}$ até sessenta dias após a rejeição ou perda de eficácia de medida provisória, as relações jurídicas constituídas e decorrentes de atos praticados durante sua vigência conservar-se-ão por ela regidas.

$\S 12$. Aprovado projeto de lei de conversão alterando o texto original da medida provisória, esta manter-se-á integralmente em vigor até que seja sancionado ou vetado o projeto.

A função legislativa própria do Poder Legislativo não pode ser exercida pelo Presidente da República, tampouco por qualquer dos órgãos do Poder Executivo, salvo nas hipóteses e nos limites expressamente previstos na Constituição Federal. Qualquer outra forma de exercício desta função consistirá em burla às liberdades fundamentais e violação ao art. $5^{\circ}$, inciso II, da Constituição Federal. Neste particular, cabe lembrar o entendimento de Celso Antônio Bandeira de Mello:

O versículo em pauta assume, no direito brasileiro, excepcional alcance. É que as mais temíveis agressões ao objetivo que o inspiram - defesa da liberdade e da propriedade dos indivíduos - derivam da assunção, pelo Executivo, de pretensões de ditar, com foros de legitimidade, restrições à livre atividade dos cidadãos - acontecimento que não tem sido incomum entre nós. Donde, defender a integridade do sistema constitucional como um todo, na medida em que assim se protege a parte mais vulnerável da cidadela protetora dos indivíduos e da ordenação pública nacional. ${ }^{140}$

Portanto, quando o Constituinte decidiu atribuir ao Poder Executivo função típica de lei, o fez de modo expresso: (i) mediante medida provisória, (ii) por lei delegada, (iii) em situações particulares de organização e funcionamento da administração sem aumento de

${ }^{140}$ BANDEIRA DE MELLO, Celso Antônio. Ato administrativo e direito dos administrados. São Paulo: RT, 1981, p. 86. 
despesas e para extinção de funções ou cargos públicos, quando vagos, (iv) em outros casos expressamente autorizados, como o decreto para alteração de alíquota dos impostos de caráter extrafiscal.

Além dessas atribuições constitucionais expressas, não há como a Administração inovar no ordenamento, mediante a criação de novos direitos e obrigações, ainda que autorizada por lei, que contenha expressa delegação outorgada pelo Congresso Nacional.

Entendemos que o regulamento de execução (denominado por Carlos Roberto de Siqueira Castro "delegação legislativa inominada" impropriamente, por ser competência originária do Executivo e não delegada pelo Congresso Nacional) destina-se exclusivamente ao detalhamento do conteúdo da lei, sem o poder de inovar.

Com toda razão afirma-se que o regulamento é cabível para "instrumento da adaptação ou ordenação do aparelho administrativo, tendo em vista, exatamente, a criação de condições para fiel execução das leis"141 e para "repetição da lei ou desdobramento do que nela se disse sinteticamente". ${ }^{142}$

Assim, é vedado à Administração criar novas hipóteses de sanção e de infração que não foram previstas ou foram insuficientemente previstas em lei, o que será abordado em detalhe no próximo capítulo.

Entretanto, há situações de sujeição especial em que o princípio da legalidade admite certa modulação, como apresentaremos no item 2.6.

\footnotetext{
${ }^{141}$ ATALIBA, Geraldo. O decreto regulamentar no sistema brasileiro. Revista de Direito Administrativo, $\mathrm{n}$. 97, Rio de Janeiro, FGV, s.d., p. 28.

142 BANDEIRA DE MELLO, Celso Antônio. Curso de direito administrativo. $28^{\mathrm{a}}$ ed. São Paulo: Malheiros, 2011, p. 352.
} 


\subsection{Discricionariedade administrativa}

\subsubsection{Conceito}

Marçal Justen Filho leciona que a discricionariedade é um dos temas centrais do direito administrativo, porque seu conceito retrata as alterações históricas do Estado democrático, pois "não haveria necessidade da existência da discricionariedade em um Estado autoritário, em que o governante impusesse sua vontade simplesmente por ser titular de poder de fato", ${ }^{143}$ Por outro lado, como bem leciona Karl Engisch, "o conceito de discricionariedade (poder discricionário) é um dos conceitos mais plurissignificativos e mais difíceis da teoria do Direito". 144

A principal característica da discricionariedade, mormente da Administração Pública, é a impossibilidade de revisão dos atos pelo Judiciário, se estiverem "dentro de certos limites jurídicos, cuja preterição pode, então, induzir de novo os tribunais a intervir: o 'abuso do poder discricionário', o détournement du pouvoir torna a decisão discricionária uma decisão viciada". ${ }^{145}$

Essa característica, por ser consequência do status de ato discricionário, entretanto, não pode ser utilizada para a determinação das condições em que está presente esta condição, sob pena de cair no vício de tautologia. Resta então, indagar em que situações é possível haver o poder discricionário, especialmente para não o confundir com a delegação legislativa e com a simples interpretação.

Antes de entrar propriamente no tema, faz-se necessário definir alguns termos, especialmente conceito normativo (ou jurídico), conceito indeterminado, conceito discricionário e cláusula geral.

\footnotetext{
${ }^{143}$ JUSTEN FILHO, Marçal. Curso de direito administrativo. $5^{\mathrm{a}}$ ed. São Paulo: Saraiva, 2010, p. 162.

144 ENGISCH, Karl. Introdução ao pensamento jurídico. $9^{\mathrm{a}}$ ed. Lisboa: Fundação Calouste Gulbenkian, 2004, p. 214.

145 ENGISCH, Karl. Introdução ao pensamento jurídico. 9a ed. Lisboa: Fundação Calouste Gulbenkian, 2004, p. 215.
} 


\subsubsection{Nomenclatura}

Observamos que não somente há divergência em relação ao próprio conceito de discricionariedade como também em relação a termos relacionados. ${ }^{146}$ Assim, para fins meramente didáticos, adotaremos a terminologia de Karl Engisch.

Karl Engisch define conceito indeterminado como o conceito caracterizado pela larga medida de incerteza do seu conteúdo. ${ }^{147}$ Os conceitos determinados, em oposição, são muito raros no direito e geralmente consistem em termos numéricos, como, por exemplo, litro, milha, quilograma e quilômetros por hora.

Os conceitos ainda podem ser conceitos descritivos, quando "designam descritivamente objetos reais ou objetos que de certa forma participam da realidade, isto é, objetos que são fundamentalmente perceptíveis pelos sentidos ou de qualquer outra forma" ${ }^{, 48}$, como, por exemplo, homem, morte, escuridão, vermelho e velocidade. Em oposição, os conceitos podem ser normativos (ou jurídicos), no sentido de que "só em conexão com o mundo das normas se tornam representáveis e compreensíveis" ${ }^{\text {149, }}$, como domínio, aluguel, casamento, preço vil.

Nem todo o conceito normativo é indeterminado. O casamento, por exemplo, é um conceito jurídico determinado pois seus pressupostos estão definidos de modo preciso na legislação civil. Os conceitos indeterminados normativos são aqueles que precisam de uma valoração para serem aplicados no caso concreto. ${ }^{150}$ Somente mediante atos de

\footnotetext{
${ }^{146}$ Aqui não se busca eleger uma nomenclatura melhor ou pior. Reconhecemos que a divergência se dá por razões geralmente coerentes e próprias de cada autor. Marçal Justen Filho, por exemplo, diferencia conceito jurídico indeterminado e conceito valorativo. O primeiro "envolve um juízo de conhecimento sobre os fatos, enquanto o conceito valorativo exige juízos de valor. Qualificar alguém como idoso depende da avaliação das condições físicas do sujeito. Qualificar alguém como 'honesto' depende de uma conjugação entre os valores e a situação real" (Curso de direito administrativo, p. 168-169).

${ }^{147}$ ENGISCH, Karl. Introdução ao pensamento jurídico. $9^{\mathrm{a}}$ ed. Lisboa: Fundação Calouste Gulbenkian, 2004, p. 208.

${ }^{148}$ ENGISCH, Karl. Introdução ao pensamento jurídico. 9a ed. Lisboa: Fundação Calouste Gulbenkian, 2004, p. 208.

149 ENGISCH, Karl. Introdução ao pensamento jurídico. 9a ed. Lisboa: Fundação Calouste Gulbenkian, 2004, p. 212.

${ }^{150}$ ENGISCH, Karl. Introdução ao pensamento jurídico. 9a ed. Lisboa: Fundação Calouste Gulbenkian, 2004, p. 213.
} 
valoração, de caso a caso, é que se pode identificar se um ato é obsceno, se a reputação é ilibada e se o serviço é ineficiente, por exemplo.

Neste contexto, a utilização de conceitos normativos indeterminados permite uma melhor adaptação das leis às situações submetidas ao aplicador da norma, como demonstra Karl Engisch:

Todavia, os conceitos normativos objetivos conservam uma propriedade, uma vantagem, podemos dizer, que frequentemente os conceitos descritivos perdem: através das valorações a que eles remetem, podem adaptar-se elasticamente à configuração particular das circunstâncias do caso concreto e ainda a qualquer mudança das concepções valorativas. Precisamente por isso é que eles são os pontos de apoio e os veículos dum 'Direito equitativo' e são tão benquistos nos tempos de hoje. O conceito descritivo 'cópula' não é capaz de individualização e de variação como o conceito 'conduta contrária aos deveres do matrimônio' ou o conceito 'ato indecoroso'. Assim, o juiz ou o funcionário administrativo que têm de referir e subsumir um caso concreto a um conceito normativoobjetivo precisam de realizar uma concretização específica. ${ }^{151}$

Cláusula geral, afirma Karl Engisch, consiste em "uma formulação da hipótese legal que, em termos de grande generalidade, abrange e submete a tratamento jurídico todo um domínio de casos"152, em contrapartida à casuística que "é aquela configuração da hipótese legal (enquanto somatório dos pressupostos que condicionam a estatuição) que circunscreve particulares grupos de casos na sua especificidade própria"153.

Esta distinção, como afirma o próprio autor, é apenas relativa. No Código Penal da Alemanha, ele exemplifica, o tipo do crime de lesão corporal qualificado tem como um dos elementos a perda de função de "um membro importante do corpo". Esta expressão é uma cláusula geral enquanto não há enumeração das partes do corpo que a lei considera como importantes. Por outro lado, ela se revela casuística se comparada à disposição concebida pelo

151 ENGISCH, Karl. Introdução ao pensamento jurídico. $9^{\mathrm{a}}$ ed. Lisboa: Fundação Calouste Gulbenkian, 2004, p. 239-240.

152 ENGISCH, Karl. Introdução ao pensamento jurídico. $9^{\mathrm{a}}$ ed. Lisboa: Fundação Calouste Gulbenkian, 2004, p. 229.

153 ENGISCH, Karl. Introdução ao pensamento jurídico. $9^{\mathrm{a}}$ ed. Lisboa: Fundação Calouste Gulbenkian, 2004, p. 228. 
governo soviético de Munique na primavera de 1919: “Toda ofensa dos princípios será punida. A determinação da natureza da pena cabe à livre discrição do juiz". ${ }^{154}$

Os conceitos discricionários são caracterizados pelo direito e pela lei, "quando a decisão última sobre o justo (correto, conveniente, apropriado) no caso concreto é confiada à responsabilidade de alguém, é deferida à concepção (em particular, à valoração) individual da personalidade chamada (eventualmente 'articulando' o seu ponto de vista com a deliberação tomada no seio de uma agremiação ou colégio) a decidir em concreto, e isto não apenas porque não é possível excluir um "resto" de insegurança, mesmo através de regras, por mais minuciosas que estas sejam, mas porque se considera ser melhor solução aquela em que, dentro de determinados limites, alguém olhado como pessoa consciente da sua responsabilidade, faça valer o seu próprio "ponto de vista'!"155

Assim, nem todo o conceito jurídico indeterminado é discricionário. A condição de uma ato ser ou não passível de revisão pelo Judiciário é atribuída pelo direito vigente, de modo que uma mesma expressão possa ser discricionária em um país e não ser em outro. Afinal, conforme Hartmut Maurer, a Administração Pública é “determinada pelas circunstâncias políticas, sociais, econômicas, técnicas e culturais de seu tempo, em que não só as condições e desenvolvimentos reais, mas também as idéias e esperanças são determinantes". 156

Os limites da discricionariedade da Administração pública não foram sempre os mesmos. Historicamente observa-se uma modificação ao longo do tempo de modo a ampliar o controle sobre os atos administrativos. Parte-se de uma idéia de ampla liberdade, como se verifica na obra de Paul Laband ${ }^{157}$, perpassando por uma concepção de limitação para

\footnotetext{
${ }^{154}$ ENGISCH, Karl. Introdução ao pensamento jurídico. 9a ed. Lisboa: Fundação Calouste Gulbenkian, 2004, p. 230-231.

155 ENGISCH, Karl. Introdução ao pensamento jurídico. 9a ed. Lisboa: Fundação Calouste Gulbenkian, 2004, p. 221-222.

${ }^{156}$ MAURER, Hartmut. Direito administrativo geral. Barueri: Manole, 2006, p. 13. Grifos no original.

157 Segundo Paul Laband, na obra Das Staatsrecht des Deutschen Reiches, cuja primeira edição é de 1878, somente quando os atos da Administração atingem os direitos individuais e o patrimônio das pessoas é que deverá haver vinculação à lei. Afora, há o poder discricionário da Administração de regular a "sua própria conduta no interior do domínio onde a sua vontade é livre e faz lei", tal como uma agremiação toma suas próprias deliberações. (No original: "Quand l'administration règle sa propre conduite à l'intérieur du domaine où sa volonté est libre et fait loi (...)" (tradução livre). LABAND, Paul. Droit public de l'Empire Allemand.
} 
realização de uma ordem jurídica conforme Otto Mayer ${ }^{158}$ e prosseguindo na possibilidade de revisão judicial dos motivos do ato como em León Duguit ${ }^{159}$.

Explorando um outro plano (formal) para controle dos atos administrativos, adveio a teoria positivista de Hans $\operatorname{Kelsen}^{160}$, desenvolvida no direito administrativo especialmente por Adolfo Merkl ${ }^{161}$ preconizando o fundamento do ato na lei autorizadora, excluindo aspectos finalísticos.

Paris: V.Giard \& Brière, 1901, t. 2., p. 519-520.)

${ }^{158}$ Otto Mayer, ainda no início do século XX, quando se buscava maior controle da Administração, a definia como "a atividade do Estado para a realização de seus propósitos e sob sua ordem jurídica" (no original: "L'administration est l'activité de l'Etat pour la réalisation de ses buts et sous son ordre juridique" (tradução livre). MAYER, Otto. Le droit administratif allemand. Paris: V. Giard \& E.Brière, 1903, t. 1, p. 81.). Este direcionamento, segundo o autor, era presente mesmo quando a lei conferia espaço para a administração decidir. Assim, nas situações em que a lei não determinava estritamente a atividade a ser executada, poderiam surgir espaços para a administração decidir quando: (i) a lei atribuia à administração a decisão de executar ou não a atividade; (ii) a lei estatuia uma fórmula incompleta que devia ser preenchida pela administração e (iii) a lei podia não tomar qualquer decisão e outorgar uma "autorização geral para, em determinado objeto ou grupo de matérias, prover o que pareça necessário e conveniente ao interesse público" (no original: "une autorisation générale, celle de pouvoir, pour un certain objet ou pour un certain circle d'affaires, à ce qui lui semble nécessaire et convenable dans l'intérêt public qui lui est confié" (tradução livre). Idem, p. 107). Este poder derivado da lei não era livre tal como o de um indivíduo no exercício de seus direitos civis. "Tudo o que faz a administração, fora a aplicação pura e simples, para realizar, completar, substituir a vontade da lei, está sob a direção mais ou menos estreita da lei; ela deve desse modo exercer seus poderes, não como um proprietário, mas como um serventuário da lei. A característica da função administrativa, tal que resulta desta dependência jurídica, é designado pela noção da execução (Vollziehung). A execução, esta é a ação da administração conforme a direção mais ou menos estreita que a lei lhe confere". (no original: "... tout ce que fait l'administration, même en dehors de l'application pure et simple, pour réaliser, compléter, remplacer la volonté de la loi, est sous la direction pluss ou moins étroite de celle-ci; elle doit ainsi exercer ses pouvoirs, non pas comme un propriétaire, mais comme une servante de la loi. Le caractère du rôle de l'administration, tel que'il résulte de cette dépendance juridique, est désigné par la notion de l'exécution (Vollziehung). L'exécution, c'est l'action de l'administration conforme à la direction plus ou moins étroite que la loi lui donne." (tradução livre). Idem. p. 108.)

${ }^{159}$ No caminho da gradual limitação da discricionariedade, reconheceu-se a possibilidade de revisão judicial dos motivos ( que são os pressupostos de fato e de direito em que se baseia o ato administrativo). Para León Duguit, este controle somente seria possível quando determinado de acordo com o princípio da legalidade. DUGUIT, Léon. Traité de Droit Constitutionnnel. 2. ed. Paris: Fontemoing, 1923, t.2, p. 89-90.

${ }^{160}$ A partir do modelo próprio positivista de Hans Kelsen, a discricionariedade decorrente da própria necessidade de interpretação e de detalhamento da lei, dentro de uma ordem hierárquica na qual "cada grau da ordem jurídica constitui, pois, ao mesmo tempo, uma produção de direito com respeito ao grau inferior e uma reprodução do direito com respeito ao grau superior"(KELSEN, Hans, Jurisdição constitucional. $2^{\mathrm{a}}$ ed. São Paulo: Martins Fontes, 2007, p. 126.). Dentro do quadro formado pelas possibilidades oferecidas pela regra de grau superior, o aplicador tem plena liberdade de escolha, exercendo um ato de vontade, uma vez que o interesse público e os fins do legislador passam a ser considerados questões morais e, portanto, situamse fora do direito.

${ }^{161}$ Adolfo Merkl, seguindo a linha de Hans Kelsen, afirma que o ato não necessita espelhar a lei, basta que esta autorize a Administração a realizá-lo, ou que seja possível vinculá-lo à lei ou dela derivar, de modo que a Administração somente pode agir se a lei assim permitir. Assim, o "sentido jurídico do princípio da legalidade consiste em que cada uma das ações administrativas seja condicionada por uma lei formal, da qual deve resultar a licitude ou a necessidade jurídicas da ação administrativa em questão" (tradução livre). No original: "El sentido jurídico del principio de legalidad consiste en que cada una de las acciones 
Atualmente é reconhecido não só o controle judicial no plano formal e da conformidade do ato com o interesse público, como também da subjetividade do agente público, tendo como referência padrões morais ${ }^{162}$ e de razoabilidade $^{163}$ do ato administrativo.

\subsubsection{Discricionariedade e vinculação}

A vinculação e discricionariedade são dois polos que não se excluem, mas que convivem na aplicação das normas. Na realização de ato administrativo o agente público normalmente estará vinculado à lei e ao mesmo tempo dispõe de certo grau de discricionariedade que pode variar de acordo com determinadas circunstâncias.

A discricionariedade não é um fenômeno homogêneo, que se traduz sempre em termos idênticos. A margem de autonomia deixada pela norma legislada ao aplicador é variável em face de cada caso. Pode-se imaginar que a absoluta e exaustiva disciplina legislativa é um caso extremamente raro. É possível dizer, então, que a discricionariedade comporta graus de autonomia, que variam em cada hipótese. Neste sentido, leciona Marçal Justen Filho:

administrativas se halla condicionada por una ley formal, de la que debe resultar la licitud o la necesidad jurídicas de la acción administrativa en cuestión". MERKL, Adolf. Teoría general del derecho administrativo. Granada: Comares, 2004. p. 217.

162 Os conceitos normativos passam a ter valorações objetivas, de acordo com as concepções morais dominantes ou de correspondentes setores sociais, mas não excluem a subjetividade do aplicador. Essa subjetividade é limitada por circunstâncias próprias, como segue: “A propósito saliente-se uma vez mais que, como já acima observamos, o quadro ou moldura de decisão pessoal não só é restringido através de limites legais claramente visíveis, mas ainda através de outras limitações, determinadas segundo o Direito consuetudinário ou segundo a 'idéia de Direito e de Estado'. Finalmente, também a proibição da 'arbitrariedade' e da 'falta de pertinência' (Unsachlichkeit) exige consideração. Assim, por exemplo, é seguro que o juiz penal, ao calcular e fixar uma pena pecuniária, o que nós - acompanhando PETERS consideramos como sendo, dentro de certos limites, uma atividade 'discricionária', não pode, por razões meramente fiscais, recorrer à pena mais elevada possível. No seguimento destas nossas considerações havemos de pressupor que, na utilização do poder discricionário são evitados os excessos e os abusos desse poder. Neste momento estamos a supor que a decisão 'pessoal' é uma decisão ajustada (sachgerecht), proferida com base numa convicção íntima e sincera”.ENGISCH, Karl. Introdução ao pensamento jurídico. $9^{a}$ ed. Lisboa: Fundação Calouste Gulbenkian, 2004, p. 242.

${ }^{163}$ A necessidade de adequação dos atos discricionários permite ao Poder Judiciário avaliar sob o prisma da razoabilidade, que também assume papel central na atualidade. Siqueira Castro, por exemplo, fundamenta a vinculação de toda a atividade estatal ao princípio da razoabilidade, decorrente do princípio do devido processo legal expresso na Constituição de 1988, "numa espécie de síntese ou amálgama de diversos direitos fundamentais explícitos e implícitos, tudo revelando a interdependência das normas constitucionais". CASTRO, Carlos Roberto Siqueira. O devido processo legal e os princípios da razoabilidade e da proporcionalidade. $4^{\mathrm{a}}$ ed. Rio de Janeiro: Forense, 2006, p. 415. 
Por isso, a doutrina não mais usa as expressões 'ato vinculado' e 'ato discricionário'. Alguns aspectos de cada ato são vinculados ou discricionários, não $\mathrm{o}$ ato propriamente dito. É absolutamente rara a hipótese em que caiba produzir um ato isoladamente, que possa ser instrumento de competência discricionária ou vinculada. ${ }^{164}$

De um modo geral é reconhecida a necessidade de maior vínculo às normas que tratam de restrições de direitos, situações em que se exige a reserva da lei ou a legalidade estrita. Com fundamento no art. $5^{\circ}$ inciso II da Constituição Federal, Maria Sylvia Zanella Di Pietro afirma que os atos da administração que impõem obrigações ou proibições por iniciativa da própria Administração estão submetidos à legalidade estrita. ${ }^{165}$ Especificamente em relação às sanções administrativas, afirma Carlos Ari Sundfeld:

Logo, não há como o decreto - ou pior, ato de escala inferior - prever infrações e criar sanções administrativas: ou vêm dispostas em lei ou inexistem no mundo jurídico. Não melhora a situação o fato de o decreto ser editado com base em lei estipulando: 'o regulamento preverá as infrações e sanções aplicáveis para realizar os objetivos da presente lei’. Tal significaria delegação de poder legislativo, gravosa ao princípio da separação dos Poderes $\left(\mathrm{CF}, \operatorname{art.} 2^{\circ}\right)$. Não é só. No Estado de Direito, a lei traduz padrão de referência para as pessoas, antecipadamente cientes das conseqüências jurídicas (positivas ou negativas) de seus atos. ${ }^{166}$

\subsubsection{Discricionariedade e interpretação}

A diferenciação entre discricionariedade e interpretação é de grande importância, especialmente por ser a primeira um núcleo próprio da função executiva que, ao menos em tese, não pode ser apreciado pelo Poder Judiciário, como já vimos.

\footnotetext{
${ }^{164}$ JUSTEN FILHO, Marçal. Curso de direito administrativo. $5^{\mathrm{a}}$ ed. São Paulo: Saraiva, 2010, p. 180.

${ }^{165}$ DI PIETRO, Maria Sylvia Zanella. Discricionariedade administrativa na Constituição de 1988. $2^{\mathrm{a}}$ ed., $4^{\mathrm{a}}$ reimpressão. São Paulo: Atlas, 2007.

166 SUNDFELD, Carlos Ari. Direito administrativo ordenador. $1^{\mathrm{a}}$ ed., $3^{\mathrm{a}}$ tiragem. São Paulo: Malheiros, 2003, p. 80-81.
} 
O processo interpretativo pode resultar em mais de uma resolução plausível que se ajustam aos limites da lei. ${ }^{167}$ Nestes casos a escolha da melhor opção não é mais feita por critérios metodológicos jurídicos, mas por outros elementos próprios da administração. Deste modo Maria Sylvia Zanella Di Pietro diferencia a interpretação da discricionariedade, como segue:

(...) por outras palavras, se a autoridade administrativa, pelo método da interpretação, não puder chegar a uma solução única, mas a várias soluções igualmente válidas perante o direito, devendo a escolha ser feita segundo critérios puramente administrativos (e não jurídicos), estar-se-á no campo da discricionariedade. ${ }^{168}$

Esta diferenciação parece-nos a mais coerente com a atual doutrina sobre a atividade discricionária que reconhece a sua presença dentro do quadro de interpretação do direito, tal como apresentado por Karl Engisch.

\subsubsection{Utilização de conceitos técnicos}

Edmund Bernartzik demonstra que entre os conceitos indeterminados, podem-se identificar situações em que, ainda que as pessoas tenham opiniões, "não podem legitimamente pretender que só elas tenham uma opinião justa e que a das outras pessoas seja falsa", pois são juízos feitos a partir de regras técnicas. Consequentemente, "somente um reduzido número de peritos e não a generalidade das pessoas pode formar um juízo". 169 Embora inicialmente tenha defendido que estes conceitos eram discricionários, Edmund Bernatzik acabou por admitir um controle pelos Tribunais Administrativos.

O tema foi desenvolvido no direito italiano especialmente por Renato Alessi, que defendeu a possibilidade de os conceitos técnicos tanto poderem ser discricionários como vinculados.

${ }^{167}$ LARENZ, Karl. Metodologia da ciência do direito. $3^{\text {a }}$ ed. Lisboa: Fundação Calouste Gulbenkian, 1997, p. 489.

${ }^{168}$ DI PIETRO, Maria Sylvia Zanella. Discricionariedade administrativa na Constituição de 1988. $2^{\mathrm{a}}$ ed., $4^{\mathrm{a}}$ reimpressão. São Paulo: Atlas, 2007, p. 123.

${ }^{169}$ QUEIRÓ, Afonso Rodrigues. O poder discricionário da administração. $2^{\mathrm{a}}$ ed. Coimbra: Coimbra, 1948, p. 123. 
Está presente a discricionariedade quando critérios técnicos "estão efetivamente ligados aos critérios administrativos, e a questão técnica ligada à questão administrativa, de tal forma que fica absorvida a primeira". São, por exemplo, as situações em que a questão técnica é pressuposto para a decisão discricionária, como a análise técnica de um prédio que ameaça ruir e a avaliação de conveniência e oportunidade da determinação de demolição, considerando os riscos, o uso dos imóveis vizinhos, o movimento das vias públicas, entre outros fatores. ${ }^{170}$

O autor aponta outra situação de discricionariedade quando a questão seja única, mas deva ser solucionada com o emprego conjunto de critérios técnicos e administrativos. Ocorre em todos os casos em que a função administrativa é exercida por meio de atividades de ordem técnica, como a realização de obras públicas, prestação de serviços técnicos, por meio de hospitais públicos, por exemplo. O agente haverá de valorar comparativamente o interesse público concreto e o meio técnico para sua satisfação. ${ }^{171}$

Entretanto, nos casos em que os conceitos técnicos forem os únicos, não há espaço para discricionariedade.

Entendemos que o emprego de termos técnicos pela lei não implica em delegação legislativa. Quando a Lei 4.595/64 determina a expedição pelo Banco Central de normas de contabilidade para serem observadas pelas instituições financeiras, não se cria o poder de inovar no mundo jurídico, de se criar novas obrigações. O estabelecimento de critérios para escrituração de receitas bancárias é atividade típica de um reduzido número de peritos, nos termos utilizados por Edmund Bernartzik como citado acima.

Por outro lado, quando a mesma Lei 4.595/64 aponta que o Banco Central fixará regras para a concessão de empréstimos por instituições financeiras, o legislador está simplesmente deixando de tomar as decisões legislativas necessárias. Não constitui decisão

\footnotetext{
${ }^{170}$ ALESSI, Renato, Instituciones de derecho administrativo, t. 1. Barcelona: Bosch, Casa Editorial, 1974, p. 196.

${ }^{171}$ ALESSI, Renato, Instituciones de derecho administrativo, t. 1. Barcelona: Bosch, Casa Editorial, 1974, p. 197.
} 
técnica a escolha das situações em que um banco pode ou não emprestar valores, ainda que o legislador necessite, para essa decisão que seja, da orientação de economistas.

\subsubsection{Conceitos jurídicos indeterminados e delegação legislativa}

Hans Wolff e Otto Bachof criticam a visão de que "o Estado de Direito seria inimigo da discricionariedade", chegando a afirmar que "na maior parte das vezes só uma Administração de livre discricionariedade, flexível e responsável, está em condições de fazer justiça em certas situações imprevisíveis e só grosseiramente abarcáveis pelo legislador". ${ }^{172}$

Karl Engisch defende que a discricionariedade não é incompatível com o Estado de Direito, pois "no domínio da administração ou no da jurisdição, a convicção pessoal (particularmente a valoração) de quem quer que seja chamado a decidir, é elemento decisivo para determinar qual das várias alternativas que se oferecem como possíveis dentro de certo 'espaço de jogo' será havida como sendo a melhor e a ‘justa'”. ${ }^{173}$

Embora o uso de conceitos jurídicos indeterminados consista numa margem de delegação decisória pelo legislador, que amplia o quadro de interpretação possível (como apresentamos no Capítulo 1), ele se justifica quando as situações para as quais incidirá a norma legal demandam critérios próprios às situações consideradas individualmente, como já apresentamos. Na atividade sancionatória, por exemplo, permite a individualização de sanção a ser aplicada.

Outra é a situação do emprego em lei de cláusulas gerais, de tal grau de generalidade, que as decisões legislativas necessárias sejam ausentes da lei. Como já observamos, em muitos países decorre uma autorização para complementação pelo aplicador, muito comum em democracias parlamentares. Entretanto, esta delegação legislativa oblíqua, sem observação do procedimento da Constituição Federal de 1988, não é admitida no direito pátrio.

\footnotetext{
${ }^{172}$ WOLF, Hans Julius; BACHOF, Otto; STOBER, Rolf. Direito administrativo. Tradução de António Francisco de Sousa. Lisboa: Fundação Calouste Gulbenkian, 2006, p. 462.

173 ENGISCH, Karl. Introdução ao pensamento jurídico. 9a ed. Lisboa: Fundação Calouste Gulbenkian, 2004, p. 227-228.
} 
A questão referente à discricionariedade da Administração será retomada no Capítulo 4, especificamente em relação ao poder regulamentar do Conselho Monetário Nacional e do Banco Central do Brasil.

\subsection{Modulação do princípio da legalidade: sujeição especial e geral}

Como visto, os princípios da legalidade e da tipicidade vedam a atuação do Estado, no exercício da atividade regulamentar, para além do que determina a lei. Conjuntamente, eles significam que essa imposição de sanções administrativas somente pode ser procedida após a constatação inequívoca de que houve a prática de uma conduta de acordo com os elementos do tipo legal de sanção exaustivamente detalhados em lei. Entretanto, excepcionalmente, alguns autores admitem que esses princípios podem ser flexibilizados nos casos em que houver uma relação especial de sujeição do particular com o Estado. Como afirma José Cretella Júnior,

ao passo que a repressão do ilícito penal é regida pelo princípio da legalidade, a autoridade exerce o poder disciplinar pode aplicar, discricionariamente, sanções disciplinares, em virtude de infrações aos deveres da profissão, a princípios de honra, de dignidade, de ética, mesmo que não haja expressa disposição estatutária precisa a respeito. A administração age dentro das chamadas normas elásticas, flexíveis ou plásticas. ${ }^{174}$

Ocorre uma relação de sujeição especial com o poder público quando o indivíduo adere a uma relação jurídica especial com a administração pública (investidura em cargo público, beneficiário de autorização de uso de um bem público em condição especial, por exemplo). Nesses casos, observou-se que a maior proximidade entre a Administração Pública e o administrado tornava impossível a descrição em lei de todas as hipóteses de condutas reprováveis e indesejadas, em razão das infinitas possibilidades de regramento necessárias, como afirma Renato Alessi:

Tal elemento é devido ao fato de que a instituição de vínculo principal torna necessário um ingresso do particular, pessoalmente, na esfera jurídica e

${ }^{174}$ CRETELLA JÚNIOR, José. Do ilícito administrativo. Revista Forense, n. 244, Rio de Janeiro, 1973, p. 19. Grifos no original. 
material - ou ainda que simplesmente jurídica - da Administração, a fim de tornar necessária uma especial disciplina mais acentuada - fundada precisamente em um estado de sujeição especial do indivíduo - do comportamento pessoal do próprio particular, a fim de obter uma melhor implementação do vínculo. Típico exemplo de contato do indivíduo com a esfera jurídica da administração, verifica-se no caso do exercício de uma função ou de um serviço público, seja quem o execute entre no âmbito da verdadeira e própria administração pública, seja permaneça, ao invés, na condição de privado. ${ }^{175}$ (tradução livre)

Cabe destacar, como exemplo, a Lei 8.112, que dispõe sobre o Regime Jurídico dos Servidores Públicos da União, cujo texto segue:

Art. 117. Ao servidor público é proibido:

$\mathrm{XV}$ - proceder de forma desidiosa.

Ao definir as atitudes proibidas, o legislador utilizou o que Karl Engish denomina de "conceitos carecidos de um preenchimento valorativo". Como já afirmado, o processo pelo qual é conhecido o conteúdo desta norma é o de interpretação, pois restrito aos possíveis sentidos que podem ser deduzidos dentro dos limites estabelecidos pelo significado literal dos termos.

Já o inciso XVIII (do mesmo artigo) deixa, implicitamente, para a Administração Pública, por meio do poder regulamentar, detalhar o modo pelo qual o servidor público deve proceder, definindo em normativos internos o que é, ou não, incompatível com o serviço público:

Art. 117. Ao servidor público é proibido:

\footnotetext{
175 No original: "Tale elemento è dato dal fatto che l'attuazione del rapporto principale renda necessario un ingresso del privato, personalmente, nella sfera giuridica e materiale - od anche semplicemente giuridica dell'ammisistrazione, in guisa da rendere necessaria una speciale disciplina più accentuata - fondata appunto su di uno stato di speciale soggezione dell'individuo - del comportamento personale del privato stesso, al fine di ottenere una migliore attuazione del rapporto. Tipico esempio di contatto dell'individuo con la sfera giuridica dell'amministrazione, si ha nel caso dell'esercizio di una funzione o di un servizio pubblico, sia che chi li eserciti entri nell'ambito della vera e propria amministrazione pubblica, e sia che rimanga, invece, in veste di privato”. ALESSI, Renato. Diritto amministrativo. Milano: Giuffrè, 1949, p. 181-182.
} 
$(\ldots)$

XVIII - exercer quaisquer atividades que sejam incompatíveis com o exercício do cargo ou função e com o horário de trabalho.

É de ressaltar que, para Celso Antônio Bandeira de Mello, a relação de supremacia ou sujeição especial repousa na concepção de reserva de lei para casos em que "é inequivocamente reconhecível a existência de relações específicas intercorrendo entre o Estado e um círculo de pessoas que nelas se inserem, de maneira a compor situação jurídica muito diversa da que atina à generalidade das pessoas”. Estas situações "demandam poderes específicos, exercitáveis, dentro de certos limites, pela própria Administração". ${ }^{176}$ Como exemplifica o autor, não há como o Legislativo dispor detalhadamente sobre o funcionamento e as regras de conduta de todos os usuários que se utilizam dos colégios públicos, universidades, museus, repartições públicas, hospitais, entre outros.

Entretanto, de acordo com Celso Antônio Bandeira de Mello, para que seja caracterizada uma relação de sujeição especial é necessária a reunião dos seguintes condicionantes positivos: (i) o poder deve encontrar seu fundamento último em lei, que deve tratar da sua atribuição a determinado órgão ou cargo público, com as respectivas especificações; (ii) o fundamento do poder decorre da própria relação especial com o Estado; (iii) os poderes devem limitar-se estritamente ao cumprimento de suas finalidades; (iv) os poderes devem observar os princípios da razoabilidade e da proporcionalidade e (v) o objeto deve manter-se "relacionado tematicamente e, em geral, tecnicamente com a relação especial que esteja em causa". ${ }^{177}$

Por sua vez, a atividade econômica em geral é norteada pela livre iniciativa que está expressa no art. 170 da Constituição Federal, que enuncia os "princípios gerais da atividade econômica":

\footnotetext{
${ }^{176}$ BANDEIRA DE MELLO, Celso Antônio. Curso de direito administrativo. $28^{\mathrm{a}}$ ed. São Paulo: Malheiros, 2011, p. 832-833.

${ }^{177}$ BANDEIRA DE MELLO, Celso Antônio. Curso de direito administrativo. 28 a ed. São Paulo: Malheiros, 2011, p. 834-835.
} 
Art. 170. A ordem econômica, fundada na valorização do trabalho humano e na livre iniciativa, tem por fim assegurar a todos existência digna, conforme os ditames da justiça social, observados os seguintes princípios:

I - soberania nacional;

II - propriedade privada;

III - função social da propriedade;

IV - livre concorrência;

$\mathrm{V}$ - defesa do consumidor;

VI - defesa do meio ambiente, inclusive mediante tratamento diferenciado conforme o impacto ambiental dos produtos e serviços e de seus processos de elaboração e prestação;

VII - redução das desigualdades regionais e sociais;

VIII - busca do pleno emprego;

IX - tratamento favorecido para as empresas de pequeno porte constituídas sob as leis brasileiras e que tenham sua sede e administração no País.

Parágrafo único. É assegurado a todos o livre exercício de qualquer atividade econômica, independentemente de autorização de órgãos públicos, salvo nos casos previstos em lei.

Mesmo quanto há planejamento efetuado pelo Estado, a Constituição de 1988 afirma que ele é meramente indicativo para o setor privado, o que reforça mais ainda a ideia de liberdade de iniciativa:

Art. 174. Como agente normativo e regulador da atividade econômica, o Estado exercerá, na forma da lei, as funções de fiscalização, incentivo e planejamento, sendo este determinante para o setor público e indicativo para o setor privado.

Como sustenta Heraldo Garcia Vitta, o "Estado poderá, por meio de lei, determinar balizas, traçar parâmetros para atuação da ordem econômica, por 
exemplo, regulando a livre concorrência e a defesa do consumidor" ${ }^{178}$ Entretanto, somente existe a necessidade de prévia autorização do Estado para o exercício da atividade econômica em situações especiais e quando expressamente determinado por lei.

Mas em determinadas atividades econômicas existe a necessidade de prévia autorização do Estado para o seu exercício, como as instituições financeiras, seguradoras, de previdência e de capitalização. Nesses casos, há um grande interesse público em que não venham a ser provocados danos para a população em geral.

Voltaremos ao tema no Capítulo 4, quando a questão será abordada em relação ao Sistema Financeiro Nacional.

${ }^{178}$ VITTA, Heraldo Garcia. A sanção no direito administrativo. São Paulo: Malheiros, 2003, p. 83. 


\section{INFRAÇÕES E SANÇÕES ADMINISTRATIVAS}

\subsection{Introdução}

Uma das principais dificuldades no tratamento da sanção administrativa é decorrente da falta de criteriosa separação do seu regime jurídico e outros análogos com os quais muitas vezes se confunde.

Neste capítulo buscar-se-á identificar o que são efetivamente as sanções administrativas. Inicialmente será apresentado um breve histórico ${ }^{179} \mathrm{e}$, em seguida, serão apresentados os elementos característicos da sanção administrativa, as medidas não repressoras decorrentes do poder de polícia e a sanção contratual. Finalmente, será verificada a forma com que o princípio da legalidade informa a atuação do Estado em cada um desses regimes.

\subsection{Ideia de sanção}

Para Hans Kelsen, entre outros autores, as normas jurídicas são necessariamente dotadas de coerção (entendida em seu sentido amplo, o que compreende sanções e medidas assecuratórias), de tal modo que:

uma conduta somente se pode considerar como prescrita, nos termos desse ordenamento - e, portanto, no caso do ordenamento jurídico, como juridicamente prescrita -, se a conduta oposta é pressuposto de uma sanção. Se uma ordem jurídica ou uma lei feita pelo parlamento contém uma norma que prescreve uma determinada conduta e uma outra norma que liga à nãoobservância da primeira uma sanção, aquela primeira norma não é uma norma autônoma, mas está essencialmente ligada à segunda; ela apenas estabelece - negativamente - o pressuposto a que a segunda liga a sanção.

179 Para um histórico dos diversos conceitos de sanção administrativa ver PRATES, Marcelo Madureira. Sanção administrativa geral: anatomia e autonomia. Coimbra: Almedina, 2005, p. 51-57. 
A noção de sanção como consequente das normas jurídicas foi objeto de forte crítica por vários autores. Hart, por exemplo, demonstra a existência de regras que não são dotadas de qualquer tipo de ameaça. As normas que atribuem poderes, como as "que definem as formas de se fazer ou celebrar contratos, testamentos ou matrimônios válidos não exigem que as pessoas ajam desta ou daquela maneira independentemente da sua vontade". ${ }^{180}$ Por esta razão, entre outras, Tércio Sampaio Ferraz Júnior afirma que a "dogmática analítica contemporânea tende a excluir a sanção como elemento necessário da estrutura da norma". ${ }^{181}$

Karl Larenz, então, observa que uma proposição jurídica completa apresenta uma estrutura lógica que consiste em uma descrição de fatos hipotéticos diante dos quais, se reunidos em uma situação de fato, terão uma ou mais consequências jurídicas específicas previstas para tanto. ${ }^{182}$ Essas consequências jurídicas consistem na "modificação no mundo juridicamente vigente". ${ }^{183}$ Elas não precisam ser necessariamente o surgimento ou extinção de um dever jurídico, mas também podem consistir no que se segue:

(...) a aquisição, a variação de conteúdo, a transmissão ou perda de um direito subjetivo, a aquisição ou perda de um poder jurídico (como, por exemplo, de um poder voluntário de representação ou de um poder de disposição), de uma legitimidade ou do estado jurídico de uma pessoa. ${ }^{184}$

Assim, com o específico propósito de delimitar o tema do presente trabalho, adotamos o entendimento de que a sanção não é elemento integrante de uma proposição jurídica. Desse modo, as sanções podem conter a descrição de fatos que não são desejados em um determinado ordenamento jurídico, que os define como condutas ilícitas, e para os quais as consequências jurídicas são, entre outras, medidas

${ }^{180}$ HART, Herbert Lionel Adolphus. O conceito de direito. São Paulo: Martins Fontes, 2009, p. 37.

${ }^{181}$ FERRAZ JÚNIOR, Tércio Sampaio. Introdução ao estudo do direito. $4^{\mathrm{a}}$ ed. São Paulo: Atlas, 2003, p. 121.

182 LARENZ, Karl. Metodologia da ciência do direito. $3^{\text {a }}$ ed. Lisboa: Fundação Calouste Gulbenkian, 1997, p. 380.

${ }^{183}$ LARENZ, Karl. Metodologia da ciência do direito. $3^{\text {a }}$ ed. Lisboa: Fundação Calouste Gulbenkian, 1997, p. 357.

184 LARENZ, Karl. Metodologia da ciência do direito. $3^{\text {a }}$ ed. Lisboa: Fundação Calouste Gulbenkian, 1997, p. 357 . 
desfavoráveis para o propósito imediato de punir o autor da conduta e, indiretamente, de desestimular outras práticas e ainda, eventual e subsidiariamente, de recompor eventual dano. ${ }^{185}$

\subsection{Sanção e infração administrativas - antecedente e consequente}

Infrações e sanções administrativas são termos interligados pelo silogismo básico se A então $B$. Ou seja, na presença de uma infração administrativa deve ser aplicada a correspondente sanção administrativa, sendo traço característico de ambas a vinculação ao exercício da função administrativa, como afirma Celso Antônio Bandeira de Mello:

Infração e sanção administrativa são temas indissoluvelmente ligados. A infração é prevista em uma parte da norma, e a sanção em outra parte dela. Assim, o estudo de ambos tem que ser feito conjuntamente, pena de sacrifício da inteligibilidade quando da explicação de uma ou de outra.

Infração administrativa é o descumprimento voluntário de uma norma administrativa para o qual se prevê sanção cuja imposição é decidida por uma autoridade no exercício de função administrativa - ainda que não necessariamente aplicada nesta esfera. ${ }^{186}$

Assim, a infração administrativa é o antecedente da consequente sanção administrativa. Uma integra o conceito da outra, de modo que não é possível a segmentação de qualquer uma.

\subsection{Conceito de infração administrativa}

Edmir Netto de Araújo, em sua tese de doutorado de 1983, publicada em livro em 1994 e que, com outros autores, deu início aos debates atuais sobre a sanção administrativa, conceitua a infração como ilícito praticado por servidor público: “o ilícito administrativo tem como condição de existência a ação ou omissão

185 KELSEN, Hans. Teoria pura do direito. $7^{a}$ ed. São Paulo: Martins Fontes, 2006, p. 61.

186 BANDEIRA DE MELLO, Celso Antônio. Curso de direito administrativo. $28^{\mathrm{a}}$ ed. São Paulo: Malheiros, 2011, p. 854. Grifos no original. 
antijurídica, culpável e imputável a agente público, mas tal infração não é obrigatória e cumulativamente catalogada também como ilícito penal". ${ }^{187} \mathrm{O}$ autor reconhece a identidade ontológica entre o ilícito penal e o administrativo, mas distingue a infração administrativa pela ausência da tipicidade, como segue:

A tipificação penal deve ser precisa, e o texto legal deve ser interpretado restritivamente, em razão do princípio constitucional da legalidade, que, neste caso, é a legalidade estrita. Entretanto, o seu correspondente administrativo não possui a mesma característica: na verdade, reserva-se à apuração da falta disciplinar uma certa faixa discricionária, que pode ocasionar punições administrativas residuais, mesmo em caso de absolvição no juízo criminal. ${ }^{188}$

Considerando que Edmir Netto de Araújo restringe o conceito de ilícito administrativo às relações sob regime jurídico de servidor público, sob sujeição jurídica especial, não há grande divergência em relação aos demais autores. Entretanto não podemos adotar este conceito pois o conjunto de relações objeto deste trabalho situa-se fora da relação de vínculo de servidor público e mesmo fora da sujeição especial, como veremos adiante.

Regis Fernandes de Oliveira, em outro trabalho inaugural, define a infração administrativa como "comportamento típico, antijurídico, cuja sanção é aplicada por órgão administrativo, ou pelos órgãos judicial ou legislativo, no exercício de função atípica". ${ }^{189}$ O comportamento típico é aquele que corresponde ao tipo previsto na norma extraída da lei e em regulamento, que vem a detalhar o conteúdo da primeira. Quanto aos elementos do tipo, Regis Fernandes de Oliveira apresenta estrutura semelhante àquela do direito penal, como segue:

Os elementos do tipo dividem-se em objetivos, subjetivos e normativos: os primeiros dizem respeito ao lugar, tempo, condições do sujeito e objeto da ação punível; os segundos dizem respeito ao fim visado pelo agente, o

\footnotetext{
${ }^{187}$ ARAÚJO, Edmir Netto de. O ilícito administrativo e seu processo. São Paulo: RT, 1994, p. 28.

${ }^{188}$ ARAÚJO, Edmir Netto de. O ilícito administrativo e seu processo. São Paulo: RT, 1994, p. 30.

${ }^{189}$ OLIVEIRA, Regis Fernandes de. Infrações e sanções administrativas. $2^{\mathrm{a}}$ ed. revista, atualizada e ampliada São Paulo: RT, 2005, p.19.
} 
intuito que o animou à prática do ato; os últimos conduzem a um juízo de valor em relação aos pressupostos do injusto típico ('sem licença de autoridade competente', 'funcionário público', 'sem as formalidades legais', 'decoro', 'injusta' e outras expressões jurídicas ou extrajurídicas que exigem uma compreensão geral do direito ou da realidade social). Faltando algum destes elementos, desde que expressos no tipo, não haverá infração. ${ }^{190}$

Maria Sylvia Zanella Di Pietro anuncia, no âmbito do processo administrativo, o princípio da atipicidade: "ao contrário do direito penal, em que a tipicidade é um dos princípios fundamentais, decorrente do postulado segundo o qual não há crime sem lei que o preveja (nullum crimem, nulla poena sine lege), no direito administrativo prevalece a atipicidade, no sentido de que muitas infrações administrativas não são descritas com precisão na lei”. ${ }^{191}$ Esta afirmação gerou certa reação por parte da doutrina, acreditamos que mais pela aparência do que pelo efetivo conteúdo. $^{192}$

A autora traz como exemplo a ausência no Estatuto dos Funcionários Públicos Civis do Estado de São Paulo (Lei 10.261/68) de conceitos para definir o que seja falta grave, procedimento irregular de natureza grave e incontinência pública e escandalosa, às quais são cominadas, respectivamente, penas de suspensão, demissão e demissão a bem do serviço público. ${ }^{193}$ Primeiramente, trata-se de situação típica de sujeição especial decorrente de relação de emprego ou de investidura de cargo público que é reconhecida por grande parte da doutrina como exceção ao princípio da legalidade. Antecedente à relação decorrente da prática de infração, há o ingresso do suposto infrator a um regime jurídico específico no qual há relação hierárquica com o superior a quem é atribuída a competência de gerenciamento da sua atividade por atos infralegais. Logicamente, a lei não poderia prever todas as hipóteses de descumprimento de cada atribuição de cada um dos servidores públicos.

${ }^{190}$ OLIVEIRA, Regis Fernandes de. Infrações e sanções administrativas. $2^{\mathrm{a}}$ ed. revista, atualizada e ampliada São Paulo: RT, 2005, p. 21.

${ }^{191}$ DI PIETRO, Maria Sylvia Zanella. Direito administrativo. $23^{\mathrm{a}}$ ed. São Paulo: Atlas, 2010, p. 633.

192 OLIVEIRA, Regis Fernandes de. Infrações e sanções administrativas. $2^{\mathrm{a}}$ ed. revista, atualizada e ampliada São Paulo: RT, 2005, p. 21; FERREIRA, Daniel. Sanções administrativas. São Paulo: Malheiros, 2001, p. 99-100; FERREIRA, Daniel. Teoria geral da infração administrativa a partir da Constituição Federal de 1988. Belo Horizonte: Fórum, 2009, p. 251-252.

${ }^{193}$ DI PIETRO, Maria Sylvia Zanella. Direito administrativo. 23a ed. São Paulo: Atlas, 2010, p. 633. 
Observa-se que o Estatuto faz uso de expressões que carecem de preenchimento valorativo, para as quais a lei nem poderia conceituar. Como já apresentamos no capítulo anterior, são conceitos normativos indeterminados (nos termos de Karl Engisch), cujo conteúdo e extensão são em larga medida incertos e que demandam do aplicador a execução de atos de valoração, diante dos fatos. Neste caso, o agente público, ao aplicar a sanção, estará dentro dos limites de interpretação da norma e não no âmbito do desenvolvimento do direito.

A outra situação apresentada é a do art. 87 da Lei de Licitações e Contratos Administrativos, a Lei 8.666/93, que se limita a descrever como infração "inexecução total ou parcial do contrato". Mais uma vez há sujeição especial decorrente do vínculo estabelecido pelo contrato administrativo. A interpretação da norma necessariamente deverá levar em conta a cláusula estabelecida entre as partes e que foi descumprida.

Maria Sylvia Zanella Di Pietro destaca que, nestas circunstâncias, a discricionariedade é "bastante reduzida pelo exame do motivo, ou seja, dos fatos que cercaram a prática do ato ilícito". ${ }^{194}$ Quanto à eleição da penalidade a ser aplicada, não há juízo baseado em "razões de oportunidade ou conveniência". ${ }^{195}$ A Administração “terá que levar em conta o princípio da razoabilidade, em especial em seu aspecto de proporcionalidade dos meios aos fins". ${ }^{196}$ Mais uma, vez, portanto, é esclarecido que se trata de um processo de interpretação de uma norma, sujeito, portanto, ao controle de legalidade pelo Poder Judiciário.

A crítica direcionada a Maria Sylvia Zanella Di Pietro acaba então por se limitar ao preciosismo do termo atipicidade, enquanto ausência do dever de exaurimento da descrição das hipóteses de infração e da sanção, mediante conceitos definidos em lei. Esta procura de rigor na acepção do termo deve ser vista com certa reserva, pois o próprio significado de "tipicidade" resulta de um equívoco na

\footnotetext{
${ }^{194}$ DI PIETRO, Maria Sylvia Zanella. Direito administrativo. $23^{\mathrm{a}}$ ed. São Paulo: Atlas, 2010, p. 633.

${ }^{195}$ DI PIETRO, Maria Sylvia Zanella. Direito administrativo. 23a ed. São Paulo: Atlas, 2010, p. 634.

${ }^{196}$ DI PIETRO, Maria Sylvia Zanella. Direito administrativo. $23^{\mathrm{a}}$ ed. São Paulo: Atlas, 2010, p. 634.
} 
importação do termo Tatbestand do alemão. ${ }^{197}$ Como informa Misabel Abreu Machado, "no direito penal e tributário, entretanto, o que se denomina de tipo é, exatamente, o oposto: o conceito determinado, fechado e classificatório". ${ }^{198}$ Igualmente leciona Heleno Fragoso:

A expressão tipo não é empregada pela lei. Ela constitui tradução livre da palavra alemã Tatbestand, correspondendo à figura puramente conceitual elaborada pela doutrina. Tipo não é o fato delituoso em sua realidade fenomênica, mas, sim, a descrição legal de um fato que a lei proíbe ou ordena. ${ }^{199}$

Ricardo Lobo Torres informa que o Tatbestand não se confunde com o princípio da determinação (Grundsatz der Bestimmtheit em alemão). ${ }^{200} \mathrm{O}$ primeiro parte da reunião de elementos com características comuns e, por isso, é sempre aberto $^{201}$, como segue:

Tipo é a ordenação dos dados concretos existentes na realidade segundo critérios de semelhança. Nele há abstração e concretude, pois é encontrado assim na vida social como na norma jurídica. (...) O tipo representa a média ou a normalidade de uma determinada situação concreta, com as suas conexões de sentido. Segue-se, daí, que a noção de tipo admite as dessemelhanças e as especificidades, desde que não se transformem em desigualdade ou anormalidade. Mas o tipo, embora obtido por indução a partir da realidade social, exibe também aspectos valorativos. O tipo, pela

\footnotetext{
197 "Diante da confusão introduzida na temática da tipicidade pelas fontes ibéricas, com grande repercussão sobre a doutrina e a jurisprudência brasileiras, poder-se-ia também falar, embora só fosse correto parcialmente, em tipicidade como princípio da adequação do fato gerador concreto ao abstrato (Grundsatz der Tatbestandmässigkeit). Mas nos parece que a identificação da tipicidade com o princípio da determinação (Grundsatz der Bestimmtheit) é exagero positivista proveniente das doutrinas portuguesa e espanhola, embora haja um certo relacionamento entre o tipo e a determinação do fato gerador, quando aquele se incluir na descrição da hipótese de incidência”. TORRES, Ricardo Lobo. Tratado de direito constitucional financeiro e tributário. Volume 2. Rio de Janeiro: Renovar, 2005, p. 468-69.

${ }^{198}$ DERZI, Misabel Abreu Machado. Direito tributário, direito penal e tipo. $2^{\mathrm{a}}$ ed. São Paulo: RT, 2007, p. 151.

${ }^{199}$ FRAGOSO, Heleno. Lições de Direito Penal. $16^{\mathrm{a}}$ ed. Rio de Janeiro: Forense, 2003, p. 187. Grifos no original.

200 TORRES, Ricardo Lobo. Tratado de direito constitucional financeiro e tributário. Volume 2. Rio de Janeiro: Renovar, 2005, p. 481.

${ }^{201}$ LARENZ, Karl. Metodologia da ciência do direito. $3^{\text {a }}$ ed. Lisboa: Fundação Calouste Gulbenkian, 1997, p. 655-660.
} 
sua própria complexidade, é aberto, não sendo suscetível de definição, mas apenas de descrição. ${ }^{202}$

Já o princípio da determinação "postula que todos os elementos do fato gerador abstrato sejam indicados com clareza na lei formal". ${ }^{203}$ Como ensina Ricardo Lobo Torres, "esse princípio da determinação se expressou, na tradição ibérica, com especial ressonância no Brasil, como princípio da tipicidade, pela confusão feita entre o tipo legal e o fato gerador abstrato". ${ }^{204}$

Portanto, resta claro que, ao enunciar o princípio da atipicidade, Maria Sylvia Zanella Di Pietro busca chamar atenção para as situações em que "muitas das infrações administrativas não são descritas com precisão na lei". ${ }^{205}$ Por outro lado, ausente o vínculo que dá origem à sujeição especial, “os atos que impliquem restrições ao exercício de direitos têm que ter previsão em lei formal ou em atos normativos que tenham a mesma força de lei, como medida provisória ou lei delegada”. 206

Cabe uma breve observação em relação ao elemento subjetivo do tipo nas infrações administrativas. Ao contrário do direito penal, em que há exigência de dolo ou culpa, no direito administrativo, considerável parcela dos autores, entre os quais Celso Antônio Bandeira de Mello $^{207}$ e Daniel Ferreira ${ }^{208}$, entende que basta a mera voluntariedade do agente, ou seja, a possibilidade de escolha entre a prática da infração ou não.

\footnotetext{
${ }^{202}$ TORRES, Ricardo Lobo. Tratado de direito constitucional financeiro e tributário. Volume 2. Rio de Janeiro: Renovar, 2005, p. 469-470.

${ }^{203}$ TORRES, Ricardo Lobo. Tratado de direito constitucional financeiro e tributário. Volume 2. Rio de Janeiro: Renovar, 2005, p. 481.

${ }^{204}$ TORRES, Ricardo Lobo. Tratado de direito constitucional financeiro e tributário. Volume 2. Rio de Janeiro: Renovar, 2005, p. 481.

${ }^{205}$ DI PIETRO, Maria Sylvia Zanella. Direito administrativo. $23^{\mathrm{a}}$ ed. São Paulo: Atlas, 2010, p. 634.

${ }^{206}$ DI PIETRO, Maria Sylvia Zanella. Discricionariedade administrativa na Constituição de 1988. $2^{\mathrm{a}}$ ed., $4^{\mathrm{a}}$ reimpressão. São Paulo: Atlas, 2007, p. 60.

207 BANDEIRA DE MELLO, Celso Antônio. Grandes temas de direito administrativo. São Paulo: Malheiros, 2009, p. 363.

${ }^{208}$ FERREIRA, Daniel. Teoria geral da infração administrativa a partir da Constituição Federal de 1988. Belo Horizonte: Fórum, 2009, p. 269.
} 
Outro elemento do conceito apresentado é a antijuridicidade. A infração deve ser uma proposição jurídica que contém a descrição de fato ilícito, que não é desejado em um determinado ordenamento jurídico. Não pode ser infração administrativa um ato lícito, pois, se é admitido pelo direito, a Administração não pode restringir a sua prática sob pena de o objetivo da sanção passar a ser meramente arrecadatório (se esta for uma multa) ou alguma outra forma de desvio de finalidade.

Regis Fernandes de Oliveira, aproximando a sanção administrativa da sanção penal, apresenta o ilícito como sinônimo de antijurídico, conforme a teoria finalista adotada pelo direito penal:

Podemos afirmar, em conceito amplo, que ilícito é o comportamento contrário àquele estabelecido pela norma jurídica, que é pressuposto da sanção. É a conduta contrária à devida. É o antijurídico. Neste sentido, ilicitude e antijuridicidade são sinônimos e confundem-se num mesmo conceito, de unívoco conteúdo. (...) Mesmo um inimputável pode praticar um fato típico e antijurídico, é dizer, pode praticar um crime, apenas não é apenado, se a sanção for privativa de liberdade. Isso porque, com a teoria finalista da ação, adotada pelo nosso Código Penal, a culpabilidade não integra o crime, constituindo-se no pressuposto da imposição da pena, mesmo porque o dolo e a culpa passaram a integrar o tipo, saindo da culpabilidade. ${ }^{209}$

Apresentamos, assim, o conceito analítico de infração administrativa, que pode ser utilizado em relações de sujeição geral e do qual decorrem algumas características que apresentaremos a seguir.

\subsection{Características da infração administrativa}

Não há um consenso sobre os elementos (ou características) definidores das sanções administrativas. No entanto, a partir da proposta de Fábio

${ }^{209}$ OLIVEIRA, Regis Fernandes de. Infrações e sanções administrativas. $2^{\mathrm{a}}$ ed. revista, atualizada e ampliada São Paulo: RT, 2005, p. 18. 
Medina Osório ${ }^{210}$, podemos destacar quatro delas, a partir das quais é possível delimitar um regime jurídico próprio: (i) elemento subjetivo: a autoridade administrativa, (ii) elemento objetivo: efeito aflitivo da medida em que se exterioriza, (iii) elemento teleológico: finalidade repressora (punição do infrator) e desestimuladora da conduta e (iv) elemento formal: natureza administrativa do procedimento.

\subsubsection{Elemento subjetivo: a autoridade administrativa}

O primeiro elemento característico da infração administrativa é o sujeito competente para impor sua correspondente sanção. Como afirma Celso Antônio Bandeira de Mello, "reconhece-se a natureza administrativa de uma infração pela natureza da sanção que lhe corresponde, e se reconhece a natureza da sanção pela autoridade competente para impô-la" ${ }^{211}$. Esta deverá ser necessariamente um agente no exercício da função administrativa.

Infração administrativa ${ }^{212}$ é o motivo de um ato administrativo, praticado por um agente no exercício da função administrativa, que aplica uma sanção específica ao caso concreto, entendido motivo como "pressuposto de fato e de direito que serve de fundamento ao ato administrativo". ${ }^{213}$

Rafael Munhoz de Mello destaca o sujeito competente como elemento decisivo para identificar a sanção e a infração administrativas, pois "se a medida não é imposta pela Administração Pública, de sanção administrativa não se trata".

\footnotetext{
${ }^{210}$ MEDINA OSÓRIO, Fábio. Direito administrativo sancionador. $3^{\mathrm{a}}$ ed. São Paulo: RT, 2009, p. 78.

${ }^{211}$ BANDEIRA DE MELLO, Celso Antônio. Curso de direito administrativo. $28^{\mathrm{a}}$ ed. São Paulo: Malheiros, 2011, p. 854.

${ }^{212} \mathrm{O}$ termo infração administrativa tem uma dupla acepção. A partir do silogismo se A então $B$, a infração administrativa é o antecedente da norma, enquanto a sanção administrativa é o consequente. Infração também pode ser o ato praticado pelo administrado perante o qual a administração impõe a sanção.

${ }^{213}$ DI PIETRO, Maria Sylvia Zanella. Direito administrativo. 23 ed. São Paulo: Atlas, 2010, p. 210.
} 
Há, por outro lado, o entendimento de que mesmo no exercício da função jurisdicional é possível a aplicação de sanções administrativas. Para Fábio Medina Osório ${ }^{214}$, por exemplo, o conceito de infração administrativa engloba também as hipóteses em que há multas aplicadas pelo Poder Judiciário.

Não configura, portanto, elemento indissociável da sanção administrativa a figura da autoridade administrativa, visto que podem as autoridades judiciárias, de igual modo, aplicar essas medidas punitivas, desde que outorgada, por lei, a respectiva competência repressiva, na tutela de valores protegidos pelo Direito Administrativo. ${ }^{215}$

Concordamos com Rafael Munhoz de Mello, que critica esse entendimento, pois "no desempenho das atividades jurisdicionais os magistrados exercem função jurisdicional, e não administrativa", assim, se "seus atos não são disciplinados pelo direito administrativo; não se há de falar, portanto, em direito administrativo sancionador". 216

\subsubsection{Elemento objetivo: efeito aflitivo da medida em que se exterioriza}

O segundo elemento da infração é a previsão de consequências jurídicas que são medidas administrativas desfavoráveis. A Administração Pública, no exercício de sua competência sancionadora, aplica uma medida com caráter aflitivo ao infrator, punindo-o pela prática do ilícito administrativo. A consequência jurídica é um mal, uma situação desfavorável. Essa aflição, entretanto, não pode consistir em pena privativa de liberdade, pois esta só pode ser imposta por autoridade judiciária, conforme art. 5º inciso LXI, da Constituição Federal, salvo prisão administrativa militar.

\footnotetext{
214 Quanto à legitimidade do Poder Judiciário para aplicar sanções administrativas, à luz da concepção material deste regime jurídico, ver: MEDINA OSÓRIO, Fábio. Direito administrativo sancionador. $3^{\mathrm{a}} \mathrm{ed}$. São Paulo: RT, 2009, p. 85-93. Sem entrar no mérito da questão, para o presente trabalho será adotado o critério formal segundo o qual as autoridades judiciária e legislativa podem impor sanções administrativas desde que no exercício das funções administrativas, conforme entendimento defendido por Heraldo Garcia Vitta (A sanção no direito administrativo, p. 33).

${ }^{215}$ MEDINA OSÓRIO, Fábio. Direito administrativo sancionador. $3^{\mathrm{a}}$ ed. São Paulo: RT, 2009, p. 85.

${ }^{216}$ MELLO, Rafael Munhoz de. Princípios constitucionais de direito administrativo sancionador: as sanções administrativas à luz da Constituição Federal de 1988. São Paulo: Malheiros, 2007, p. 67.
} 


\subsubsection{Elemento teleológico: finalidade repressora (punição do infrator) e desestimuladora da conduta}

O terceiro elemento é o propósito imediato de punir o autor da conduta e, indiretamente, de desestimular outras práticas. Como afirma Rafael Munhoz de Mello, "reconhecer que a sanção retributiva esgota-se na imposição de um mal ao infrator não significa aceitar que a finalidade de tal medida seja a de punir". ${ }^{217}$ Sua finalidade é preventiva: pune-se para prevenir a ocorrência de novas infrações, desestimulando a prática de comportamentos tipificados como ilícitos". 218

Também nesse tema não há unanimidade na doutrina. Há autores que defendem ainda o caráter indenizatório da sanção administrativa, especialmente em relação à imposição de multa em dinheiro. Segundo Hely Lopes Meirelles, por exemplo, a multa administrativa é "toda imposição pecuniária a que se sujeita o administrado a título de compensação do dano presumido da infração".219

Dessa forma, mostra-se apropriada a classificação apresentada por Celso Antônio Bandeira de Mello, entre multas exclusivamente intimidadoras, ressarcitórias e as astreintes:

Por serem a modalidade sancionadora mais comum, as multas merecem referência especial. Todas as sanções - e, portanto, também as multas cumprem uma função intimidadora e exemplar; mas, entre elas, podem ser discernidas (a) as que se limitam a cumprir esta finalidade; as que, (b) além disto, visam a ressarcir a Administração de algum prejuízo que a ação ou inação do administrado lhe causou - são as multas ressarcitórias, reparatórias ou compensatórias -, bem como aqueloutras (c) de caráter cominatório, que, visando a compelir o administrado a uma atuação positiva, se renovam automática e continuadamente até a satisfação da pretensão

\footnotetext{
${ }^{217}$ MELLO, Rafael Munhoz de. Princípios constitucionais de direito administrativo sancionador: as sanções administrativas à luz da Constituição Federal de 1988. São Paulo: Malheiros, 2007, p. 76.

${ }^{218}$ MELLO, Rafael Munhoz de. Princípios constitucionais de direito administrativo sancionador: as sanções administrativas à luz da Constituição Federal de 1988. São Paulo: Malheiros, 2007, p. 76.

${ }^{219}$ MEIRELLES, Hely Lopes. Direito administrativo brasileiro. $20^{\mathrm{a}}$ ed. atualizada por Eurico de Andrade Azevedo et al. São Paulo: Malheiros, 1995, p. 870.
} 
administrativa. São o que no Direito Francês se denomina astreinte, e seu mecanismo é o equivalente das imposições cominatórias feitas em juízo. ${ }^{220}$

Floriano de Azevedo Marques Neto afirma que sanção e indenização não se confundem, "podendo uma e outra medida jurídica ser adotadas independentemente". ${ }^{221}$ A primeira "visa a resguardar interesses gerais da coletividade (metaindividuais e abstratos), enquanto a responsabilidade civil se volta a reparar danos dos consumidores (individuais e concretos)". ${ }^{222}$ Por outro lado, reconhece que há uma aproximação entre ambos os regimes, como segue:

Há de admitir, no entanto, que a prática administrativista moderna tem promovido uma aproximação entre as duas responsabilidades acima descritas. E esta aproximação decorre do fato de que as finalidades de um e outro instrumento jurídico são semelhantes (a proteção do usuário, do consumidor, da coletividade de fruir da utilidade pública), divergindo apenas no ângulo protetivo (a reparação visa ao indivíduo - interesse concreto e individual -, enquanto a sanção visa à coletividade - interesse difuso, metaindividual). Tal aproximação ilustra uma perceptível tendência contemporânea de superar a vetusta dicotomia interesse público versus interesses privados.

Nosso entendimento é de que a sanção administrativa destina-se à imposição de um mal ao infrator. Apenas em caráter indireto, ou oblíquo, pode ter natureza ressarcitória ou compensatória, sob pena de se tornar indenização.

\footnotetext{
${ }^{220}$ BANDEIRA DE MELLO, Celso Antônio. Curso de direito administrativo. $28^{\mathrm{a}}$ ed. São Paulo: Malheiros, 2011, p. 828.

${ }^{221}$ MARQUES NETO, Floriano Azevedo. Aspectos jurídicos do exercício do poder de sanção por órgão regulador do setor de energia elétrica. Boletim de direito administrativo, n. 12, São Paulo, 2002, p. 960.

${ }^{222}$ MARQUES NETO, Floriano Azevedo. Aspectos jurídicos do exercício do poder de sanção por órgão regulador do setor de energia elétrica. Boletim de direito administrativo, n. 12, São Paulo, 2002, p. 960.
} 


\subsubsection{Elemento formal: natureza administrativa do procedimento}

Este elemento existe porque a sanção se constitui por meio de um ato administrativo decorrente de um procedimento no qual é garantido ao particular o direito à ampla defesa e ao devido processo legal.

\subsection{Conceito de poder de polícia}

O poder de polícia encontra-se definido no artigo 78 do Código Tributário Nacional, nos seguintes termos:

Art. 78. Considera-se poder de polícia atividade da administração pública que, limitando ou disciplinando direito, interesse ou liberdade, regula a prática de ato ou abstenção de fato, em razão de interesse público concernente à segurança, à higiene, à ordem, aos costumes, à disciplina da produção e do mercado, ao exercício de atividades econômicas dependentes de concessão ou autorização do Poder Público, à tranqüilidade pública ou ao respeito à propriedade e aos direitos individuais ou coletivos. ${ }^{223}$

O poder de polícia constitui atividade de atuação do Estado para garantir conformidade ao exercício dos direitos do administrado com o ordenamento jurídico, a fim de preservar a ordem pública, a segurança, a saúde da população e o meio ambiente. Os atos administrativos, pelos quais se exerce o poder de polícia, em geral $^{224}$ estão dotados dos atributos da imperatividade ${ }^{225}$ e da autoexecutoriedade ${ }^{226}$,

\footnotetext{
${ }^{223}$ Redação dada pelo Ato Complementar 31, de 28.12.1966.

224 Como já afirmamos em outra oportunidade, os atributos dos atos administrativos (a presunção de legitimidade, a imperatividade e a autoexecutoriedade) não podem ser considerados definitivos e presentes em todas as possibilidades jurídicas e fáticas existentes, podem prevalecer, ou não, de acordo com as circunstâncias de fato e não mantêm com os direitos individuais uma relação de precedência geral. TOGNETTI, Eduardo. Atributos do ato administrativo. In: DI PIETRO, Maria Sylvia Zanella; RIBEIRO, Carlos Vinícius Alves (Orgs.). Supremacia do interesse público, e outros temas relevantes do direito administrativo. São Paulo: Atlas, 2010, p. 360-361.

${ }^{225} \mathrm{O}$ atributo da imperatividade dos atos administrativos consiste na possibilidade, que tem o poder público de, por meio de atos unilaterais, impor obrigações a terceiros.

${ }^{226}$ Maria Sylvia Zanella Di Pietro conceitua o termo autoexecutoriedade como "atributo pelo qual o ato administrativo pode ser posto em execução pela própria Administração Pública, sem necessidade de intervenção do Poder Judiciário" (Direito administrativo, p. 200). Alguns autores, como Celso Antônio Bandeira de Mello, desdobram a autoexecutoriedade em dois outros conceitos: exigibilidade ("a qualidade em virtude da qual o Estado, no exercício da função administrativa, pode exigir de terceiros o cumprimento, a
} 
dispensando prévia concordância de terceiros e autorização judicial, respectivamente, para compelir os administrados ao seu cumprimento.

Nesse sentido, sustenta Celso Antônio Bandeira de Mello:

Em face de todo o exposto, pode-se definir a polícia administrativa como $a$ atividade da Administração Pública, expressa em atos normativos ou concretos, de condicionar, com fundamento em sua supremacia geral e na forma da lei, a liberdade e a propriedade dos indivíduos, mediante ação ora fiscalizadora, ora preventiva, ora repressiva, impondo coercitivamente aos particulares um dever de abstenção ('non facere') a fim de conformar-lhes os comportamentos aos interesses sociais consagrados no sistema normativo. $^{227}$

Deste mesmo poder de polícia derivam as denominadas "providências acautelatórias", que consistem em uma reação do Estado à ilegalidade presente, iminente ou potencial. Estas prescindem de prévio processo administrativo e do exercício à ampla defesa do administrado nos casos de urgência, como segue:

\begin{abstract}
Providências administrativas acautelatórias são medidas que a Administração muitas vezes necessita adotar de imediato para prevenir danos sérios ao interesse público ou à boa ordem administrativa e cuja finalidade não é - como a das sanções - intimidar eventuais infratores para que não incorram em conduta ou omissão indesejada, mas, diversamente, é a de paralisar comportamentos de efeitos danosos ou de abortar a possibilidade de que se desencadeiem. ${ }^{228}$
\end{abstract}

No mesmo sentido, afirma Rafael Munhoz de Mello:

\footnotetext{
observância, das obrigações que impôs", Curso de direito administrativo, p. 419) e executoriedade ("qualidade pela qual o Poder Público pode compelir materialmente o administrado, sem precisão de buscar previamente as vias judiciais, ao cumprimento da obrigação que impôs e exigiu”, Curso de direito administrativo, p. 419).

${ }^{227}$ BANDEIRA DE MELLO, Celso Antônio. Curso de direito administrativo. $28^{\mathrm{a}}$ ed. São Paulo: Malheiros, 2011, p. 844. Grifos no original.

${ }^{228}$ BANDEIRA DE MELLO, Celso Antônio. Curso de direito administrativo. $28^{\mathrm{a}}$ ed. São Paulo: Malheiros, 2011, p. 866-867. Grifos no original.
} 
A vinculação absoluta entre ilícito e sanção distingue a medida sancionadora de outras medidas previstas no ordenamento jurídico, impostas pela Administração Pública para impedir a ocorrência ou a continuidade de um evento causador de danos ao interesse público. Trata-se de medidas preventivas, já que adotadas pelos agentes administrativos para evitar a consumação ou agravamento de uma violação à ordem pública. Não se confundem com as sanções administrativas, portanto, pois estas são medidas que pressupõem justamente a consumação de um comportamento ilícito.

É o que ocorre com algumas medidas de polícia administrativa. No exercício do poder de polícia a Administração Pública pode atuar de modo concreto para prevenir a ocorrência de atos contrários ao interesse público, conformando o agir dos particulares aos limites normativos. ${ }^{229}$

No entanto, não se devem confundir as sanções administrativas com os demais atos derivados do poder de polícia. Como já definido acima, a sanção administrativa é a reação do Estado a uma conduta indesejada praticada pelo particular. Dessa forma, são impostas restrições que não visam de imediato à preservação da ordem ou do bem comum. Pelo contrário, são restrições à liberdade individual que constituem um sofrimento indesejado com a finalidade mediata de servir de desestímulo para os demais.

Não prestam, portanto, para obstar a ocorrência iminente ou atual de uma conduta ilegal, contrária ao direito, mas para punição daquele que consumou ${ }^{230}$ a prática de conduta correspondente aos elementos de uma infração prevista em lei. Por essa razão, o exercício do devido processo legal ${ }^{231}$ e o direito à ampla defesa pelo

\footnotetext{
${ }^{229}$ MELLO, Rafael Munhoz de. Princípios constitucionais de direito administrativo sancionador: as sanções administrativas à luz da Constituição Federal de 1988. São Paulo: Malheiros, 2007, p. 82.

230 “Como as infrações administrativas consumam-se no momento de sua prática, inadmissível falar-se em tentativa de infração, como categoria lógica e jurídica. É possível sua existência, mas não se conhece texto no direito brasileiro que contemple a hipótese. Os atos anteriores à consumação não se ajustam ao tipo". OLIVEIRA, Regis Fernandes de. Infrações e sanções administrativas. $2^{\mathrm{a}}$ ed. revista, atualizada e ampliada São Paulo: RT, 2005, p. 102.

${ }^{231} \mathrm{O}$ devido processo legal deve ser aqui entendido não somente no seu sentido adjetivo ou processualista, mas também na sua dimensão substantiva que consiste na exigência de uma decisão justa e de acordo com o princípio da razoabilidade. Para aprofundamento do tema, ver CASTRO, Carlos Roberto Siqueira. O devido processo legal e os princípios da razoabilidade e da proporcionalidade. $4^{\mathrm{a}}$ ed. Rio de Janeiro: Forense, 2006.
} 
administrado precedem a aplicação da sanção administrativa pelo Estado, como afirma Rafael Munhoz de Mello:

Sanção administrativa é imposta sempre após o curso de processo administrativo, no qual é assegurado ao acusado o exercício de todas as garantias inerentes ao due process of law. Já a medida preventiva, aplicada justamente para evitar a ocorrência de fato danoso ao interesse público, exige pronta e imediata atuação da Administração Pública, que pode agir sem realizar prévio processo administrativo, sob pena de não atender ao interesse público. ${ }^{232}$

Luis Manuel Fonseca Pires destaca a diferença entre estes dois regimes jurídicos que não se confundem, pois a sanção pressupõe sempre a prática de um ato ilícito, enquanto as limitações administrativas em geral, quando relacionadas a um ilícito, apenas buscam impedir a sua prática ou minimizar seus efeitos indesejados, como segue:

A distinção entre limitações administrativas e sanções administrativas pode ser bem demarcada: as primeiras podem decorrer da prática de um ilícito administrativo, as segundas pressupõem sempre o ilícito; as primeiras, quando são deflagradas por conta de um ilícito, buscam a simples recomposição da ordem jurídica, o que pode levar à suspensão de uma atividade ilícita, a apreensão de bens, a autuação e imposição de multa, tudo tendo sempre o devido processo legal presente, mas que pode anteceder ou ocorrer imediatamente após o ato de limitação administrativa, enquanto as sanções são a imposição efetiva e conseqüente exigibilidade de reprimendas que sempre exigem o prévio contraditório. Ou em outras palavras: enquanto a limitação administrativa admite, desde que necessário, a dilação do devido processo legal para momento instantaneamente posterior à sua prática, pois diante do ilícito o escopo premente é o restabelecimento da ordem jurídica, a efetiva imposição de sanção não cede nunca a ser impingida só após o contraditório e a ampla defesa. O que se quer dizer ainda é que a limitação administrativa e a sanção administrativa não se associam de modo a toda vez que se encontre uma também esteja presente a outra, pois nem sempre

${ }^{232}$ MELLO, Rafael Munhoz de. Princípios constitucionais de direito administrativo sancionador: as sanções administrativas à luz da Constituição Federal de 1988. São Paulo: Malheiros, 2007, p. 83-84. 
haverá uma limitação administrativa a anteceder o devido processo legal que tenciona a eventualmente imputar a sanção administrativa, uma vez que casos de ilícitos administrativos podem haver que o dano consumado não permite a recomposição ao stato quo ante nem há a necessidade de suspender a continuação da atividade do administrado, mas restará a possibilidade, mesmo assim, de aplicação da respectiva sanção administrativa. ${ }^{233}$

Fábio Medina Osório igualmente alerta para exclusão da sanção administrativa do conceito de poder de polícia:

Neste estreito espaço, adota-se a idéia de que o poder administrativo de polícia é a faculdade de que dispõe a Administração Pública para condicionar e restringir o uso e o gozo de bens, atividades e direitos individuais, em benefício da coletividade e do próprio Estado. É o mecanismo de frenagem de que dispõe a Administração para conter os abusos do direito individual. Assim, atividades como a construção, a indústria de alimentos ou remédios, o uso das águas, a exploração das florestas ou das minas, além de atividades relacionadas à segurança, saúde e moralidade públicas, e tantas outras, estão sujeitas ao poder de polícia, seja geral, seja especial.

É certo que as medidas de polícia podem estar ligadas ao cometimento ou ao perigo de cometimento de um fato ilícito, mas tal circunstância não lhes confere um caráter punitivo, um enquadramento no conceito de sanções administrativas. $^{234}$

A distinção entre sanção, enquanto consequência da prática de ato ilícito, e outras medidas adotadas pelo Estado para assegurar direitos também foi tratada por Hans Kelsen, ao analisar os "atos coercitivos que não têm o caráter de sanção", como segue:

Distinguem-se destas sanções, como já notamos, apenas na medida em que estes atos de coerção não são ligados, como conseqüências, a uma

233 PIRES, Luis Manuel Fonseca. Limitações administrativas à liberdade e à propriedade. São Paulo: Quartier Latin, 2006, p. 300-301. Grifos no original.

${ }^{234}$ MEDINA OSÓRIO, Fábio. Direito administrativo sancionador. $3^{\text {a }}$ ed. São Paulo: RT, 2009, p. 105. 
determinada ação ou omissão socialmente indesejável e juridicamente fixada, porquanto o seu pressuposto não é um ato ilícito ou um delito juridicamente prefixado e cometido por um determinado indivíduo. $\mathrm{O}$ ato ilícito ou o delito é uma determinada ação ou omissão humana que, por ser socialmente indesejável, é proibida pelo fato de a ela ou, mais corretamente, à sua verificação num processo juridicamente regulado se ligar um ato de coerção, pelo fato de a ordem jurídica a tornar pressuposto de um ato de coerção por ela estatuído. E este ato de coerção apenas pode, como sanção (no sentido de conseqüência de um ato ilícito), distinguir-se de outros atos de coerção estatuídos pela ordem jurídica na medida em que o fato condicionante ou pressuposto deste ato de coerção é uma determinada ação ou omissão socialmente indesejável e juridicamente prefixada, ao passo que os atos de coerção não qualificados como sanções, no sentido de conseqüências do ilícito, são condicionados por outros fatos. ${ }^{235}$

Cabe destacar que esta distinção entre regimes jurídicos não é acolhida pela unanimidade dos autores, especialmente por Hely Lopes Meirelles. Observa-se no seu trabalho o tratamento conjunto e indistinto de ambos os conceitos. Para melhor ilustrar, pode ser citada a seguinte passagem:

As sanções do poder de polícia, como elemento de coação e intimidação, principiam, geralmente, com a multa e se escalonam em penalidades mais graves como a interdição de atividade, o fechamento de estabelecimento, a demolição de construção, o embargo administrativo da obra, a destruição de objetos, a inutilização de gêneros, a proibição de fabricação ou comércio de certos produtos; a vedação de localização de indústrias ou de comércio em determinadas zonas; e tudo o mais que houver de ser impedido em defesa da moral, da saúde e da segurança pública, bem como da segurança nacional, desde que estabelecido em lei ou regulamento. ${ }^{236}$

\footnotetext{
${ }^{235}$ KELSEN, Hans. Teoria pura do direito. $7^{\mathrm{a}}$ ed. São Paulo: Martins Fontes, 2006, p. 44-45.

${ }^{236}$ MEIRELLES, Hely Lopes. Direito administrativo brasileiro. $20^{\mathrm{a}}$ ed. atualizada por Eurico de Andrade Azevedo et al. São Paulo: Malheiros, 1995, p. 123-124. Grifos no original.
} 
Para Carlos Ari Sundfeld, a medida cautelar e a sanção administrativa são formas de atividades repressivas ligadas ao poder de polícia. ${ }^{237}$ Por outro lado, o autor distingue estes dois regimes jurídicos, conforme trecho abaixo:

(...) a sanção de interdição do estabelecimento depende de procedimento em que, ademais de se comprovar a infração, seja garantido o direito de defesa, com todos os seus desdobramentos, demandando prazo relativamente longo. A solução para, nessas hipóteses, evitar o perigo, não é - como supõem certos administradores - aplicar imediatamente a sanção, lançando ao punido o ônus de desconstituir o ato sancionador. Aceita-se apenas a interdição cautelar, até a conclusão do procedimento. Tal medida não é sancionadora, mas acauteladora, o que, se por um lado dispensa o procedimento para garantia do direito de defesa, por outro impede a imposição de gravames desnecessários à cessação do perigo, bem como implica em que, constatada posteriormente a falsidade da imputação, sejam cabalmente indenizados os prejuízos causados pela aplicação da medida. ${ }^{238}$

Boa parte da dificuldade na identificação desses dois regimes jurídicos decorre da possibilidade de eles serem aplicados pela mesma forma. A apreensão de um produto, por exemplo, pode ser igualmente uma sanção ou uma medida acautelatória, a depender das circunstâncias. Neste sentido, Celso Antônio Bandeira de Melo leciona que a Administração estará no exercício do poder de polícia, "quando a adoção da medida for urgente para a defesa do interesse público e não comportar as delongas naturais do pronunciamento judicial sem sacrifício ou risco para a coletividade". ${ }^{239}$ Essa afirmação inicialmente leva a crer que a apreensão de bens tenha este regime jurídico necessariamente. Entretanto, o próprio autor admite a possibilidade de ser aplicada como modalidade de sanção, por exemplo, “de equipamentos de pesca ou de caça utilizados fora das normas". 240

\footnotetext{
237 SUNDFELD, Carlos Ari. Direito administrativo ordenador. $1^{\mathrm{a}}$ ed., $3^{\mathrm{a}}$ tiragem. São Paulo: Malheiros, 2003, p. 77.

238 SUNDFELD, Carlos Ari. Direito administrativo ordenador. $1^{\text {a }}$ ed., $3^{\text {a }}$ tiragem. São Paulo: Malheiros, 2003, p. 78.

${ }^{239}$ BANDEIRA DE MELLO, Celso Antônio. Curso de direito administrativo. $28^{\mathrm{a}}$ ed. São Paulo: Malheiros, 2011, p. 849.

${ }^{240}$ BANDEIRA DE MELLO, Celso Antônio. Curso de direito administrativo. $28^{\mathrm{a}}$ ed. São Paulo: Malheiros, 2011, p. 855.
} 
Assim, nosso entendimento é de que a sanção administrativa, pelos seus elementos objetivo, teleológico e formal, não apresenta identidade com outras medidas decorrentes do poder de polícia, ainda que estes atos possam ser exteriorizados por formas jurídicas idênticas.

\subsection{Sanção administrativa $x$ ilícito contratual}

Outra situação é a do ilícito contratual, que não advém de relação típica de direito público, mas de cominação decorrente do descumprimento de uma norma contratual, nos moldes de direito privado, ainda que temperada pelo regime jurídico de direito público aplicável.

Há hipóteses de infração decorrentes de contrato firmado com a Administração que podem estar exclusivamente previstas no corpo do instrumento, outras previstas em lei e no contrato, e ainda outras somente previstas em lei. A Lei de Licitações, por exemplo, prevê sanções para descumprimento de obrigações ainda no curso da licitação, o que seria uma fase pré-contratual.

Mesmo que a infração estivesse somente prevista em um contrato típico de direito privado, ainda assim haveria a vigência do regime de direito público, motivo pelo qual o descumprimento de suas normas sujeita o particular a sanções administrativas decorrentes do regime de sujeição especial.

Assim, entendemos que não há como distinguir sanção administrativa de sanção contratual nos contratos firmados com a Administração Pública.

\subsection{Delegação legislativa em matéria de infração e sanção administrativas}

Como demonstramos no Capítulo 2, não é possível a delegação legislativa fora das hipóteses expressamente previstas na Constituição Federal. Esta 
vedação também se aplica às infrações e sanções administrativas, nas situações de sujeição geral.

Em relação à hipótese de infração, é vedada à Administração a criação de novos tipos, por meio de delegação direta ou indireta, esta mediante utilização de termos de grande generalidade, que acabam por se tornarem vagos e imprecisos. Como exemplo de delegação direta, pode-se imaginar uma infração com a seguinte hipótese: colocar, no mercado de consumo, qualquer produto ou serviço em desacordo com as normas expedidas pela Associação Brasileira de Normas Técnicas (ABNT). Nessa suposição, a lei estaria atribuindo à ABNT a liberdade de criar, de forma autônoma, novas sanções administrativas, tantas quantas forem suas normas técnicas. A hipótese legal não determina os elementos (integrantes do tipo da infração) que deveriam ser detalhados ou definidos tecnicamente pelo órgão, apenas delega a função.

A delegação da função legislativa ocorre por via oblíqua mediante a utilização de cláusulas gerais. Karl Engisch define esse modo de legislar como "uma formulação da hipótese legal que, em termos de grande generalidade, abrange e submete a tratamento jurídico todo um domínio de casos". ${ }^{241}$ Nesse caso, o aplicador da norma passa a ter ampla liberdade para a fazer incidir nas mais variadas situações, a seu exclusivo critério. Embora atendido formalmente o princípio da legalidade, ocorre violação do princípio da tipicidade, ferindo a legalidade em seu sentido material.

Ocorre delegação legislativa nas definições muito amplas de mínimo e de máximo da sanção aplicável ${ }^{242}$. Por exemplo, o art. 75 da Lei de Proteção Ambiental (Lei 9.605/98) determina que o valor da multa será fixado "no regulamento desta Lei e corrigido periodicamente, com base em índices estabelecidos na legislação pertinente, sendo o mínimo de $\mathrm{R} \$ 50,00$ (cinqüenta reais) e o máximo de $\mathrm{R} \$$ 50.000.000,00 (cinqüenta milhões de reais)". Nesse mesmo sentido, assevera Celso Antônio Bandeira de Mello:

${ }^{241}$ ENGISCH, Karl. Introdução ao pensamento jurídico. $9^{a}$ ed. Lisboa: Fundação Calouste Gulbenkian, 2004, p. 229.

${ }^{242}$ VITTA, Heraldo Garcia. A sanção no direito administrativo. São Paulo: Malheiros, 2003, p. 91. 
Assim também não se poderá considerar válida lei administrativa que preveja multa variável de um valor muito modesto para um extremamente alto, dependendo da gravidade da infração, porque isto significaria, na real verdade, a outorga de uma 'discricionariedade' tão desatada, que a sanção seria determinável pelo administrador e não pela lei, incorrendo esta em manifesto vício de falta de 'razoabilidade'. É dizer: teria havido um simulacro de obediência ao princípio da legalidade; não, porém, uma verdadeira obediência a ele. Norma que padecesse deste vício seria nula, por insuficiência de delimitação da sanção. ${ }^{243}$

Igualmente manifesta Heraldo Garcia Vitta:

Se o legislador estabelece liberdade amplíssima à autoridade para impor a penalidade administrativa, nos limites de mínimo e máximo estipulados, o particular não tem como saber, antecipadamente, qual seria a provável e específica conseqüência de sua conduta, pressuposto da pena. Isso equivaleria à inexistência de lei formal a regular a quantidade de pena a ser imposta ao infrator. ${ }^{244}$

Portanto, verifica-se a delegação legislativa em matéria de infrações e sanções administrativas quando o legislador: (i) atribui diretamente a um ente ou órgão da Administração a escolha das condutas que deverão constituir infrações com respectivas sanções, (ii) utiliza-se de termos demasiadamente vagos de modo que não seja possível identificar com clareza os elementos do tipo da infração e (iii) prevê ampla liberdade para a Administração aplicar as sanções. Estas formas de delegação não encontram amparo na Constituição, como já visto no capítulo anterior.

\subsection{Discricionariedade na aplicação de sanções}

Apresentaremos questões relacionadas à ocorrência, ou não, de poder discricionário no exercício do poder sancionatório, quando o tipo de infração legal é formado por conceitos jurídicos indeterminados, quando a lei prevê mais de uma

\footnotetext{
${ }^{243}$ BANDEIRA DE MELLO, Celso Antônio. Curso de direito administrativo. $28^{\mathrm{a}}$ ed. São Paulo: Malheiros, 2011, p. 862.

${ }^{244}$ VITTA, Heraldo Garcia. A sanção no direito administrativo. São Paulo: Malheiros, 2003, p. 91.
} 
possibilidade de sanção aplicável alternativamente e quanto à possibilidade de a Administração optar por não punir.

\subsubsection{Tipo formado com conceitos jurídicos indeterminados}

Maria Sylvia Zanella Di Pietro alerta que o tema é de ampla controvérsia, devido à dificuldade de se distinguir a discricionariedade da simples interpretação, "pois em ambas existe um trabalho intelectivo prévio à aplicação da lei aos casos concretos". ${ }^{245}$ A autora destaca a existência de linhas que negam a possibilidade da discricionariedade nos espaços conferidos pelos conceitos normativos indeterminados, reduzindo o trabalho do aplicador à mera interpretação, e outras linhas que buscam traçar a discricionariedade dentro dos limites permitidos pela interpretação. $^{246}$

As linhas que negam a discricionariedade têm por base as teorias que incluem, no processo de interpretação da norma, a adequação às condições materiais existentes, como proposto por Karl Larenz dentro dos elementos teleológico-objetivos. Entretanto, ele mesmo reconhece a discricionariedade decorrente do emprego dos conceitos indeterminados em lei, como segue:

Ora bem, pode acontecer que uma lei se sirva de um dos denominados conceitos jurídicos indeterminados, ou seja, uma pauta carecida de preenchimento, para concretizar os pressupostos adentro dos quais o órgão administrativo deve ter uma margem de discricionariedade. ${ }^{247}$

Assim, compartilhamos o entendimento manifestado por Maria Sylvia Zanella Di Pietro, para quem "se a autoridade administrativa, pelo método da interpretação, não puder chegar a uma solução única, mas a várias soluções igualmente

\footnotetext{
${ }^{245}$ DI PIETRO, Maria Sylvia Zanella. Discricionariedade administrativa na Constituição de 1988. $2^{\mathrm{a}}$ ed., $4^{\mathrm{a}}$ reimpressão. São Paulo: Atlas, 2007, p. 119.

246 Nesse sentido: MORENO, Fernando Sainz. Conceptos jurídicos, interpretación y discrecionalidade administrativa. Madri: Civitas, 1976, p. 163-165 e PIRES, Luis Manuel Fonseca, Controle judicial da discricionariedade administrativa, dos conceitos jurídicos indeterminados às políticas públicas. Rio de Janeiro: Elsevier, 2009, p. 96-97.

${ }^{247}$ LARENZ, Karl. Metodologia da ciência do direito. $3^{\mathrm{a}}$ ed. Lisboa: Fundação Calouste Gulbenkian, 1997, p. 417.
} 
válidas perante o direito, devendo a escolha ser feita por critérios puramente administrativos (e não jurídicos), estar-se-á no campo da discricionariedade". 248

\subsubsection{Mais de uma possibilidade de sanção prevista em lei}

A questão que permanece é a da previsão em lei de duas ou mais opções de sanções aplicáveis, ou ainda o estabelecimento de uma margem razoável de grau entre a sanção mínima e a máxima, se nesses casos há discricionariedade para a Administração decidir a sanção aplicável com base nos critérios de conveniência e oportunidade.

Para Hely Lopes Meirelles há discricionariedade do agente aplicador da sanção desde que haja proporcionalidade com a infração cometida, como segue:

No uso da liberdade legal de valoração das atividades policiadas e na graduação das sanções aplicáveis aos infratores é que reside a discricionariedade do poder de polícia, mas mesmo assim a sanção deve guardar correspondência e proporcionalidade com a infração. ${ }^{249}$

Esse entendimento era reforçado pelo art. $5^{\circ}$, inciso III, da Lei 1.533/51, antiga Lei do Mandado de Segurança, que restringia a apreciação pelo Poder Judiciário de atos disciplinares, salvo se praticados por autoridade incompetente e com inobservância de formalidade essencial.

Fábio Medina Osório, por outro lado, nega a existência de juízo discricionário e defende que a Administração fica vinculada à proporcionalidade na fixação da sanção imposta, como segue:

A individualização da pena confere aos sentenciados direito subjetivo público perante o Estado-juiz, analogicamente transferido às autoridades administrativas competentes, traduzindo-se em exigência de fundamentação

\footnotetext{
${ }^{248}$ DI PIETRO, Maria Sylvia Zanella. Discricionariedade administrativa na Constituição de 1988. $2^{\mathrm{a}}$ ed., $4^{\mathrm{a}}$ reimpressão. São Paulo: Atlas, 2007, p. 123.

${ }^{249}$ MEIRELLES, Hely Lopes. Direito administrativo brasileiro. $20^{\text {a }}$ ed. atualizada por Eurico de Andrade Azevedo et al. São Paulo: Malheiros, 1995, p. 120.
} 
adequada e proporcional nos moldes exemplificativos e referenciais dos vetores do art. 59 do Código Penal, dispositivo que não consagra poderes discricionários e sim conceitos jurídicos indeterminados, ao menos teoricamente.

De igual modo, prosseguindo no raciocínio paralelo, a individualização das sanções, com suporte no Direito Administrativo Sancionador, exige ato fundamentado das autoridades administrativas, daí derivando direito subjetivo público aos jurisdicionados e administrados. A motivação, aliás, é especial requisito dos atos sancionadores, o que a erige como condição de validade do ato, ligando-se, indiscutivelmente, ao princípio da individualização da sanção, além de sua autonomia enquanto requisito de fundamentação da medida.

Se cada ser humano é um indivíduo, cada infrator deve receber um tratamento individualizado, particular, com a possibilidade de conhecer as concretas e específicas razões do ato sancionador, podendo impugná-lo ou aceitá-lo. Essa individualização se aplica às pessoas jurídicas, igualmente dotadas de peculiaridades relevantes, na perspectiva de assegurar sanções proporcionais. $^{250}$

Cabe ainda destacar que existe divergência entre os ministros dos tribunais superiores. Há julgados que negam a existência de discricionariedade na fixação da quantidade de sanção a ser imposta ao infrator, como segue:

RECURSO EM MANDADO DE SEGURANÇA No 19.741 - MT (2005/0044783-5)

\section{RELATOR : MINISTRO FELIX FISCHER}

EMENTA

RECURSO ORDINÁRIO. DISCIPLINAR. MÉRITO ADMINISTRATIVO. INOCORRÊNCIA. VIOLAÇÃO AO DEVIDO PROCESSO LEGAL NO PROCESSO DISCIPLINAR. OCORRÊNCIA. RECURSO PROVIDO.

I - "Tendo em vista o regime jurídico disciplinar, especialmente os princípios da dignidade da pessoa humana, culpabilidade $e$

${ }^{250}$ MEDINA OSÓRIO, Fábio. Direito administrativo sancionador. $3^{\text {a }}$ ed. São Paulo: RT, 2009, p. 373-374. 
proporcionalidade, inexiste aspecto discricionário (juízo de conveniência e oportunidade) no ato administrativo que impõe sanção disciplinar."

II - "Inexistindo discricionariedade no ato disciplinar, o controle jurisdicional é amplo e não se limita a aspectos formais. [...]” (MS 12983/DF, Rel. Ministro FELIX FISCHER, TERCEIRA SEÇÃO, julgado em 12.12.2007, DJ 15.02.2008).

Por outro lado, a Primeira Seção do STJ julgou por unanimidade a existência da discricionariedade, como pode ser observado pela leitura da ementa:

MANDADO DE SEGURANÇA No 15.175 - DF (2010/0064492-7)

EMENTA

MANDADO DE SEGURANÇA. REINTEGRAÇÃO DE SERVIDOR PÚBLICO. PROCESSO ADMINISTRATIVO DISCIPLINAR. DEVIDO PROCESSO LEGAL ASSEGURADO. LIBERAÇÃO INDEVIDA DE CERTIDÃO NEGATIVA. PROPORCIONALIDADE DA PENA DE DEMISSÃO. ART. 132 DA LEI N. 8.112/90.

1. Não viola o princípio da proporcionalidade o ato disciplinar que, considerando a gravidade e repercussão do ilícito administrativo, impõe a penalidade de demissão prevista em lei.

2. O controle jurisdicional dos processos administrativos limita-se à observância do procedimento, à luz dos princípios do contraditório e da ampla defesa, sem exame do mérito do ato administrativo.

3. In casu, o impetrante, Técnico do Seguro Social, recebeu pena de demissão por ter a comissão processante reconhecida - após o devido processo legal administrativo - a prática de falta grave consistente na emissão de Certidões Positivas de Débito com Efeitos de Negativa, em desacordo com a legislação.

Segurança denegada.

Admitir que a sanção administrativa situa-se no âmbito da discricionariedade da Administração implica em excluir da apreciação do Poder Judiciário o principal aspecto do processo administrativo que é o seu resultado. Admitir 
essa liberdade no exercício da atividade sancionatória pode pôr em risco outras garantias fundamentais, como apresentaremos.

\subsubsection{Discricionariedade para não punir}

Marcelo Madureira Prates, entre outros autores, defende o poder amplo da Administração de analisar a conveniência e a oportunidade da apuração de infrações e da aplicação de sanções, diante de "interesses públicos de maior vulto em colisão com o interesse público sancionador" ${ }^{\text {251 }}$, como afirma. O autor esclarece que "não se trata, repare-se, de absolver uma ação comprovadamente ilícita, e sim de não aplicar uma sanção formalmente devida em face da existência e da preponderância de outros interesses públicos na hipótese". ${ }^{252}$

Para Maria Sylvia Zanella Di Pietro, não há margem de discricionariedade para a Administração, diante da ocorrência da infração, eleger se a aplicação da sanção é conveniente ou oportuna, como segue:

A discricionariedade ainda pode dizer respeito a uma escolha entre o agir e o não agir; se, diante de certa situação, a Administração está obrigada a adotar determinada providência, a sua atuação é vinculada; se ela tem possibilidade de escolher entre atuar ou não, existe discricionariedade. Sirva de exemplo o caso de ocorrência de ilícito administrativo: a Administração é obrigada a apurá-lo e a punir os infratores, sob pena de condescendência criminosa (art. 320 do Código Penal). ${ }^{253}$

De fato, em situações extremas ou muito específicas, é até exigível do agente público que deixe de apurar ou aplicar uma sanção para proteção de outro bem jurídico de maior valor. É perfeitamente aceitável, por exemplo, a conduta de um agente público que deixa de apurar determinado fato danoso ao patrimônio público por ser insignificante o seu valor perante o custo administrativo da investigação.

\footnotetext{
${ }^{251}$ PRATES, Marcelo Madureira. Sanção administrativa geral: anatomia e autonomia. Coimbra: Almedina, 2005 , p. 70 .

${ }^{252}$ PRATES, Marcelo Madureira. Sanção administrativa geral: anatomia e autonomia. Coimbra: Almedina, 2005, p. 70.

${ }^{253}$ DI PIETRO, Maria Sylvia Zanella. Direito administrativo. $23^{\mathrm{a}}$ ed. São Paulo: Atlas, 2010, p. 214.
} 
Entretanto, as situações em que há conflitos de interesses públicos, como a descrita acima, decorrem da regular interpretação da norma que deve reger a conduta do agente público, de acordo com o princípio da razoabilidade, e não propriamente de um juízo de conveniência e oportunidade.

Ademais, como tratamos no capítulo 2, a Administração age no exercício de um função pública para satisfação de um interesse coletivo. Por isso, concordamos com Celso Antônio Bandeira de Mello quando afirma que suas prerrogativas não devem ser vistas senão como "deveres-poderes", devido ao caráter instrumental, pois estes "são conferidos como meios impostergáveis ao preenchimento da finalidade que o exercente de função deverá suprir" ${ }^{254}$. Consequentemente, o dever de sancionar existe tanto para as "infrações internas quanto em relação às externas ${ }^{255}$. Admite apenas, excepcionalmente, "as situações de irrelevância, com lesividade ínfima despresível"256, a partir do princípio da insignificância.

\subsection{Sanção administrativa e sanção penal}

A questão também não é pacífica na literatura penal, especialmente diante do fato de as multas penais serem cobradas por execução fiscal (rito próprio destinado aos créditos fiscais) e da impossibilidade de conversão da multa inadimplida em outra sanção penal. ${ }^{257}$

Assim, como já apresentado no início deste capítulo, o elemento subjetivo, ou seja, a autoridade competente para impor a punição, é o principal critério para diferenciar a sanção administrativa do crime. Assim, não se pode ignorar certa identidade entre as duas formas de manifestação do mesmo poder de punir do Estado.

\footnotetext{
${ }^{254}$ BANDEIRA DE MELLO, Celso Antônio. Curso de Direito administrativo. $28^{\mathrm{a}}$ ed. São Paulo: Malheiros, 2011 , p. 98.

${ }^{255}$ BANDEIRA DE MELLO, Celso Antônio. Curso de Direito administrativo. $28^{\mathrm{a}}$ ed. São Paulo: Malheiros, 2011, p. 871.

${ }^{256}$ BANDEIRA DE MELLO, Celso Antônio. Curso de Direito administrativo. $28^{\mathrm{a}}$ ed. São Paulo: Malheiros, 2011, p. 871.

${ }^{257}$ MIRABETE, Julio Fabbrini. Manual de direito penal. São Paulo: Atlas, 1985, p. 284-291.
} 
Floriano Azevedo Marques Neto destaca a mesma natureza jurídica da pena e da sanção administrativa, como segue:

Já assinalei que a sanção administrativa tem, em essência, a mesma natureza da sanção de caráter penal. Pune o mal com o mal, com o objetivo de proteger o interesse público, atingir as finalidades eleitas como consentâneas a esse interesse (por exemplo, prestar um serviço público de qualidade). Procura inibir novas infrações, punir aquele que desobedece aos preceitos legais e às obrigações que assumiu, e servir de exemplo para desencorajar outros eventuais infratores. ${ }^{258}$

Fábio Medina Osório nega a identidade de regimes jurídicos, mas destaca que o direito administrativo e o direito penal têm igualmente fundamento na Constituição, como segue:

Imperioso examinar mais de perto as sanções penais e as administrativas, de modo a deixar bem claro o limite puramente dogmático que as separa. De fato, se o Estado possui uma unitária pretensão punitiva ou não, o certo é que este poder pode projetar-se sobre os indivíduos e sociedade por dois caminhos fundamentais e, sobretudo, distintos (sujeitos a regimes jurídicos distintos): sanções penais e sanções administrativas. Um dos grandes desafios contemporâneos é, justamente, o de aproximar e tornar mais harmônicas tais atividades - administrativa e judiciária -, na tutela de idênticos bens jurídicos, o que pode ocorrer desde distintas vertentes teóricas, institucionais e normativas.

De um lado, se a simétrica unidade do poder punitivo estatal enseja necessária incidência de alguns princípios de direito público sobre esses dois instrumentos normativos, de outra banda resulta claro que esses princípios possuem contornos próprios, distinções, regimes jurídicos diferentes, ainda que as diferenças não possam ultrapassar certas barreiras, esbarrando, pois, numa unidade nuclear inscrita na Constituição da República.

A unidade (parcial) impõe traços em comum e umas mínimas garantias, mas as diferenças impõem tratamentos desiguais justificados, desenvolvimento de princípios próprios do Direito Administrativo Sancionador, que é, antes

${ }^{258}$ MARQUES NETO, Floriano Azevedo. Aspectos jurídicos do exercício do poder de sanção por órgão regulador do setor de energia elétrica. Boletim de direito administrativo, n. 12, São Paulo, 2002, p. 955. 
de tudo, direito administrativo por excelência, até porque já não se discute que ilícitos penais e administrativos se encontram debaixo de regimes jurídicos, em sua maior parte, distintos, conquanto balizados por princípios estruturalmente muito próximos e radicalmente comuns em suas origens constitucionais.

Em realidade, a unidade nada mais é do que a comum origem constitucional: direito penal e Direito Administrativo obedecem a comandos constitucionais e, nesse sentido, submetem-se a princípios constitucionais que norteiam o poder punitivo estatal. Isso não quer dizer, em absoluto, que esses princípios sejam idênticos ou que esse poder punitivo se submeta a idênticos regimes jurídicos. ${ }^{259}$

A questão referente à aplicação dos princípios, no sentido de regras gerais, do direito penal à atividade sancionadora exercida pela Administração é de grande relevância. Afinal, o art. $5^{\circ}$, inciso XXXIX da Constituição Federal reafirma o princípio da legalidade no direito penal declarando que "não há crime sem lei anterior que o defina, nem pena sem prévia cominação legal”. Reconhecer sua aplicação às sanções administrativas implica em reconhecer que, ainda que seja atribuído amplo poder de inovação no ordenamento jurídico aos órgãos da Administração, por meio de regulamentos, estes não poderão instituir hipóteses de infração.

Por outro lado, aceitar que o art. $5^{\circ}$, inciso XXXIX não se aplica às sanções administrativas, mas apenas aos crimes, põe em risco todas as garantias e direitos previstos na Constituição. Bastaria que os órgãos públicos editassem resoluções prevendo hipóteses de infrações administrativas idênticas àquelas previstas no Código Penal. A situação restaria agravada com a aplicação do entendimento de que mesmas sanções seriam manifestação do exercício da discricionariedade e que, portanto, não poderiam ser apreciadas pelo Poder Judiciário, conforme acórdão da $1^{\circ}$ Turma do Superior Tribunal de Justiça (Mandado de Segurança n ${ }^{\circ} 15.175$, cuja ementa transcrevemos supra). As portas estariam abertas para toda a sorte de arbitrariedade e a Constituição se tornaria letra morta.

${ }^{259}$ MEDINA OSÓRIO, Fábio. Direito administrativo sancionador. $3^{\text {a }}$ ed. São Paulo: RT, 2009, p. 141 


\subsection{As sanções administrativas e o princípio da legalidade}

A partir das considerações apresentadas, pode-se concluir até agora que doutrina relevante, já citada, entende que somente por lei podem ser instituídas hipóteses de infrações administrativas e respectivas sanções aplicáveis nos casos de sujeição geral. Por outro lado, a Administração Pública não pode inovar no ordenamento jurídico senão para o estrito detalhamento do sentido possível que se pode extrair do texto legal que contiver os elementos para identificação dos tipos de infração, inclusive por preenchimento valorativo de conceitos que assim demandem. Somente nos casos em que haja mais de uma interpretação válida é que haverá espaço para discricionariedade. Já para a imposição da sanção, o agente público está adstrito aos limites estreitos de mínimo e de máximo definidos por lei e pela razoabilidade. ${ }^{260}$

Como apresentado, os regimes de sanção e de infração administrativas podem decorrer de relações de sujeição especial, em que existe uma relação hierárquica ou ainda contratual. Nestes casos não há como a lei prever em detalhes todas as hipóteses de condutas reprováveis, pelo que é necessário o estabelecimento de infrações em cláusulas contratuais, como é o caso de um contrato de concessão de serviço público. Podemos mencionar a expedição de ordens de serviços dentro de repartições públicas, contidas dentro dos limites das atribuições típicas dos servidores da repartição, cujo descumprimento injustificado poderá sujeitar o infrator a sanções genericamente previstas em lei.

\footnotetext{
${ }^{260}$ Como lembra Marcos Porta: "Como o tipo de provimento que a Administração visa obter tem efeitos restritivos de direitos à liberdade e à propriedade, esses processos administrativos sancionatórios pertencem à categoria jurídica dos processos administrativos complexos. Há, pois, acusados em geral nesses processos administrativos devendo ser assegurados o contraditório e a ampla defesa e os recursos a ela inerentes, elementos esses concretizadores do devido processo legal (art. $5^{\circ}$, incisos LIV e LV, da Constituição Federal)" (Processo administrativo e o devido processo legal, p. 92).
} 


\section{BANCO CENTRAL COMO AGÊNCIA REGULADORA}

\subsection{Introdução}

É constante a afirmação de que a atuação do Banco Central $^{261}$ é de tal forma singular que merece um tratamento especial a ponto de ter autonomia em relação ao Ministério da Fazenda e ao próprio Chefe do Poder Executivo. Estes mesmos argumentos são utilizados para até mesmo elevar a autarquia à categoria de um quarto poder, junto com o Conselho Monetário Nacional.

Funções do CMN e do Banco Central são disciplinadas pela Lei 4.595/64. São entes do Executivo que executam uma única função de regulação do Sistema Financeiro Nacional. Por isso qualificaremos os regulamentos de ambos como sendo normas expedidas pelo Banco Central. Desconsideraremos a peculiaridade de que Resoluções são emanadas do CMN e Circulares e Cartas-circulares são expedidas pelo Banco Central, visto que a dinâmica instaurada por esses órgãos é de estabelecer um único conjunto normativo.

No presente capítulo apresentaremos em linhas gerais as funções do Banco Central do Brasil dentro do modelo importado de agências reguladoras. Faremos inicialmente um breve histórico de agência reguladora, sob o enfoque do princípio da subsidiariedade, a fim de verificar se existem as condições institucionais que excluam a autarquia do regime constitucional de legalidade previsto na atual Constituição.

Em seguida, serão apresentadas as quatro teorias que buscam fundamentar que o Banco Central do Brasil e o CMN têm atribuições legislativas: a primeira, com base no regime jurídico de concessão, defendido principalmente por Arnoldo Wald; a segunda, que propõe uma mudança de paradigmas, apresentada por Tércio Sampaio Ferraz Júnior; a terceira, da capacidade normativa de conjuntura no direito

\footnotetext{
${ }^{261}$ O Banco Central do Brasil é uma autarquia federal, instituída pela da Lei 4.595, de 31.12.1964. Parte de suas atribuições era exercida anteriormente pela Superintendência da Moeda e do Crédito (SUMOC) do Banco do Brasil S.A. e pela União Federal.
} 
econômico, de Eros Roberto Grau; e a do regime de sujeição especial, de Celso Antônio Bandeira de Mello.

Finalmente serão apresentadas algumas conclusões em relação à aplicação dessas teorias diante do regime jurídico próprio do exercício do poder de punir pelo Estado.

\subsection{Modelo regulatório do Sistema Financeiro Nacional: função do CMN e do Banco Central de acordo com a Lei 4595}

Neste item apresentaremos de forma sucinta o contexto econômico, o fundamento e as características das agências reguladoras que gozam de determinada competência normativa, para verificar se o Conselho Monetário Nacional e o Banco Central se enquadram nesse modelo regulatório.

Ao longo das duas últimas décadas, especialmente com o fim da Guerra Fria, iniciou-se o declínio dos modelos de Estado do Bem-Estar Social e do Socialista. Estes modelos tinham por fundamento a execução das atividades econômicas e o fornecimento de serviços públicos prestados diretamente pelo Estado, mas acabaram por se revelar insustentáveis. Como afirma Diogo de Figueiredo Moreira Neto, esses modelos propiciavam o "desenvolvimento de uma autonomia de fato e uma burocracia própria que as afastavam da prossecução dos interesses públicos e acabavam servindo de instrumento de parasitismo e de privilégios". 262

A atuação direta do Estado na execução dessas atividades revelou-se excessivamente menos eficaz que a das empresas privadas, provocando desequilíbrio orçamentário e consequente endividamento do setor público em geral, decorrentes dos excessivos gastos, como afirma Gaspar Ariño:

Bem, no início dos anos 70, se começou a ter conhecimento sobre o caráter patológico desta situação (crescimento excessivo do setor público) no mundo

${ }^{262}$ MOREIRA NETO, Diogo de Figueiredo. Mutações do direito administrativo. Rio de Janeiro: Renovar, 2000, p. 146. 
ocidental (em ambos os regimes de direita e esquerda) e, posteriormente, nos países socialistas, após a queda do Muro de Berlim. Neste sentido, há uma certa unanimidade hoje na constatação de que o aumento significativo do setor público produz um efeito de distorção sobre a economia dos países, pois retira os recursos do setor gerador de crescimento (setor privado) para serem colocados em programas que satisfazem objetivos políticos intermináveis. Por outro lado, há contínua evidência de que o setor empresarial público, com a baixa produtividade da sua gestão, constitui atualmente um pesado fardo para o progresso social. ${ }^{263}$ (tradução livre)

Passou a ser exigida dos Estados ocidentais, inclusive, a adoção de um novo modelo baseado na eficiência e na delegação aos particulares de atividades econômicas anteriormente executadas diretamente pelo Estado ou por empresas estatais, ${ }^{264}$ denominado genericamente como o fenômeno da privatização. ${ }^{265}$

Este novo modelo demandou do Estado a assunção de um novo papel em relação ao mercado de produtos e serviços, não mais agindo diretamente para fomentar a economia, mas para regulamentá-la a fim de garantir os princípios da livre iniciativa e da função social da propriedade.

Tal modelo de Estado tem como fundamento ético o princípio da subsidiariedade $^{266}$, que "tradicionalmente conhecido pela Igreja Católica, vem, agora,

\footnotetext{
${ }^{263}$ No original: "Pues bien, a principios de los años 70, se comienza a tomar conciencia acerca del carácter patológico de esta situación (excesivo crecimiento del sector público) en el mundo occidental (tanto en regímenes de derechas como de izquierdas) y posteriormente en los países socialistas tras la caída del muro de Berlín. En este sentido hay una cierta unanimidad; hoy, en la apreciación de que el notable incremento del sector público produce un efecto distorsionante de la economía de los países, pues retira recursos del sector generador de crecimiento (el sector privado) para colocarlos en programas que satisfacen objetivos políticos inacabables. Por otro lado, hay continua evidencia de que el sector empresarial público, con la baja productividad de su gestión, constituye actualmente una pesada carga para el progreso social". ARIÑO, Gaspar. Economia y Estado. Buenos Aires: Abeledo-Perrot, 1993, p. 238. Grifos no original.

264 “O fim da soberania do estado-providência não é apenas a ruptura com o socialismo. A redução do tamanho do Estado propõe novas funções a serem assumidas. O mercado adquire soberania para escolher livremente bens e serviços a serem produzidos e a forma de fazê-los". BENJÓ, Isaac. Fundamentos de economia da regulação. Rio de Janeiro: Thex, 1999, p. 16-17.

${ }^{265}$ Para um painel geral do processo de privatização realizado nos países europeus ver ARIÑO, Gaspar. Economia y Estado. Buenos Aires: Abeledo-Perrot, 1993, p. 254-261.

266 ÁVILA, Fernando Bastos de. Pequena enciclopédia de doutrina social da Igreja. São Paulo: Loyola, 1991, p. 421.
} 
sendo utilizado pela doutrina social para vincular a ação estatal e definir o âmbito de competência do poder público". ${ }^{267}$ Essa vertente do princípio defende que o Estado deve atuar na administração do bem comum, auxiliando as pessoas e as comunidades na consecução de seus objetivos, sem se substituir a eles, como manifestado na Encíclica Quadragesimo Anno, do ano de 1931:

Verdade é, e a história o demonstra abundantemente, que, devido à mudança de condições, só as grandes sociedades podem hoje levar a efeito o que antes podiam até mesmo as pequenas; permanece contudo imutável aquele solene princípio da filosofia social: assim como é injusto subtrair aos indivíduos o que eles podem efetuar com a própria iniciativa e indústria, para o confiar à coletividade, do mesmo modo passar para uma sociedade maior e mais elevada o que sociedades menores e inferiores podiam conseguir, é uma injustiça, um grave dano e perturbação da boa ordem social. O fim natural da sociedade e da sua ação é coadjuvar os seus membros, não destruí-los nem absorvê-los. ${ }^{268}$

João Paulo II igualmente faz referência às atribuições do Estado na forma subsidiária a fim de garantir o exercício da atividade econômica:

Para a realização destes objetivos, o Estado deve concorrer tanto direta como indiretamente. Indiretamente e segundo o princípio de subsidiariedade, criando as condições favoráveis ao livre exercício da atividade econômica, que leve a uma oferta abundante de postos de trabalho e de fontes de riqueza. Diretamente e segundo o princípio de solidariedade, pondo, em defesa do mais débil, algumas limitações à autonomia das partes, que decidem as condições de trabalho, e assegurando em todo o caso um mínimo de condições de vida ao desempregado. ${ }^{269}$

Embora a subsidiariedade não seja exclusivamente um princípio informador da ordem econômica, busca "harmonizar a coexistência do poder público e da

${ }^{267}$ TORRES, Silvia Faber. O princípio da subsidiariedade no direito público contemporâneo. Rio de Janeiro: Renovar, 2001, p. 75.

268 PAPA PIO XI. Carta Encíclica Quadragesimo Anno. Disponível em: <http://www.vatican.va/holy_father/pius_xi/encyclicals/documents/hf_p-xi_enc_19310515_quadragesimoanno_po.html>. Acesso em 21 de agosto de 2008.

${ }^{269}$ PAPA JOÃO PAULO II. Carta Encíclica Centesimus Annus. São Paulo: Loyola, 1991., p. 25. 
liberdade de que goza a iniciativa privada". ${ }^{270}$. O Estado passa a intervir como regulador das atividades econômicas ${ }^{271}$, com a utilização de modelos de entidades descentralizadas especializadas em determinados setores da economia, denominadas agências reguladoras, como afirma Silvia Faber Torres:

Contudo, e ainda na esteira da subsidiariedade, que tem no afastamento dos controles excessivos e dos formalismos próprios da Administração uma de suas principais motivações, é preciso racionalizar e despolitizar a ação regulatória e fiscalizatória da Administração sobre os serviços transferidos à iniciativa privada, criando-se, como solução, instituições reguladoras independentes, profissionalizadas, protegidas por um estatuto jurídico que dê autonomia, continuidade, coerência e fidelidade aos seus próprios fins institucionais.

(...)

No Brasil surgem, dentro dessa idéia de descentralização e relativa independência do organismo administrativo incumbido de controlar a atividade pública delegada, as agências reguladoras, que além de dotadas de autonomia, ainda lhes têm outorgada competência normativa sobre a atividade que fiscalizam, o que lhes propicia atuação célere e flexível para a solução de questões em que predomine a escolha técnica, apartada das disputas partidarizadas. $^{272}$

O modelo de agência reguladora tem por base o sistema norte-americano da regulação de setores da economia e foi introduzido de modo amplo pela denominada Reforma da Gestão Pública, defendida por Bresser Pereira à época em que foi Ministro da Administração e Reforma do Estado (1995-1998), que resultou na Emenda Constitucional $n^{\circ}$ 19/1998. Dinorá Adelaide Musetti Grotti destaca que essa importação do modelo no Brasil decorre da necessidade de oferecer ao investidor estrangeiro, durante o processo de

\footnotetext{
${ }^{270}$ TORRES, Silvia Faber. O princípio da subsidiariedade no direito público contemporâneo. Rio de Janeiro: Renovar, 2001, p. 182-184..

${ }^{271}$ Diversos autores escreveram sobre as formas de intervenção do Estado. A respeito, verifica-se em Habermas uma reflexão sobre a compatibilidade da intervenção estatal (analisada sob a ótica de um Estado Social) e a autonomia das liberdades negativas. Ver HABERMAS, Jürgen. Direito e democracia: entre facticidade e validade. Volume 2. Rio de Janeiro: Tempo Brasileiro, 1997, p. 144-145.
}

272 TORRES, Silvia Faber. O princípio da subsidiariedade no direito público contemporâneo. Rio de Janeiro: Renovar, 2001, p. 182-183. 
privatização dos serviços prestados pelo Estado, formas jurídicas de regulação atrativas, como segue:

A verdade é que essa redefinição do Estado, reformulação do papel da Administração Pública ocorreu por interferência do direito estrangeiro, em especial do direito norte-americano, que exerceu uma pressão muito grande para que fossem criadas essas agências reguladoras dotadas de autonomia e especialização, com a natureza jurídica de autarquias em regime especial, vinculadas a uma determinada concepção político-ideológica que visa impedir influências políticas sobre a regulação e disciplina de determinadas matérias. Em síntese, foram criadas por exigência dos investidores estrangeiros, pois no Brasil houve a abertura para o capital estrangeiro para prestação dos serviços por concessionárias particulares e não mais estatais, e nesse contexto de mudança os investidores queriam uma garantia de que haveria uma continuidade da política econômica traçada pelo Governo. Foram criadas como autarquias, pessoas jurídicas de direito público, ou seja, aí surge a expressão, com poderes especiais. ${ }^{273}$

Maria Sylvia Zanella Di Pietro define agência, em seu sentido amplo, como "qualquer órgão da Administração Pública Direta ou Indireta com função de regular a matéria específica que lhe está afeta". ${ }^{274}$ Já em sentido restrito, com referência somente ao modelo mais recente, é a "entidade da Administração Indireta, em regra autarquia de regime especial, com a função de regular a matéria que se insere em sua esfera de competência, outorgada por lei". ${ }^{275}$

Marcos Juruena Villela Souto destaca a diferença entre agências reguladoras, "voltadas para a intervenção em mercados específicos, regulando a relação entre oferta, com qualidade e preço acessível, e demanda, e agências executivas, ligadas à implementação de política, sem formular políticas, regular ou influir em mercados". ${ }^{276}$

\footnotetext{
${ }^{273}$ GROTTI, Dinorá Adelaide Musetti. Agências Reguladoras, uma visão critica e atual. Boletim de Direito Administrativo, volume 21, n. 8, agosto 2005, São Paulo, NDJ, p. 884.

${ }^{274}$ DI PIETRO, Maria Sylvia Zanella. Parcerias na administração pública. $7^{a}$ ed. São Paulo: Atlas, 2009 , p. 179.

${ }^{275}$ DI PIETRO, Maria Sylvia Zanella. Parcerias na administração pública. $7^{\mathrm{a}}$ ed. São Paulo: Atlas, 2009, p. 179.

${ }^{276}$ SOUTO, Marcos Juruena Vellela. Desestatização, privatização, concessões, terceirizações e regulação. $4^{\mathrm{a}}$
} 
Em regra, são características próprias das agências, que determinam um regime jurídico especial, segundo Maria Sylvia Zanella Di Pietro, (i) "maior autonomia em relação à Administração Direta", (ii) "estabilidade de seus dirigentes, garantida por mandato fixo" e (iii) o "caráter final de suas decisões, que não são passíveis de apreciação por outros órgãos ou entidades da Administração Pública". ${ }^{277}$ Outros autores apresentam um rol mais extenso de características. Alexandre Santos Aragão, por exemplo, aponta que este novo modelo das agências reguladoras apresenta ainda as seguintes características: (i) autonomia, (ii) diversidade e amplitude de funções, (iii) atividade normativa, (iv) atividade fiscalizadora, (v) atividade sancionatória, (vi) atividade julgadora e a adoção da arbitragem, (vii) possível flexibilidade e consensualidade no exercício das suas funções, (viii) caráter técnico, (ix) regime de pessoal e (x) regime licitatório. ${ }^{278}$

O regime jurídico especial das agências é proporcionado por meio de um contrato de gestão com o poder público, pelo qual são estabelecidas metas a serem atingidas, tal como previsto no art. $37, \S 8^{\circ}$ da Constituição Federal, incluído pela Emenda Constitucional no 19/1998:

$\S 8^{\circ} \mathrm{A}$ autonomia gerencial, orçamentária e financeira dos órgãos e entidades da administração direta e indireta poderá ser ampliada mediante contrato, a ser firmado entre seus administradores e o poder público, que tenha por objeto a fixação de metas de desempenho para o órgão ou entidade, cabendo à lei dispor sobre:

I - o prazo de duração do contrato;

II - os controles e critérios de avaliação de desempenho, direitos, obrigações e responsabilidade dos dirigentes;

III - a remuneração do pessoal.

Especificamente em relação ao Sistema Financeiro Nacional, não há a figura do contrato de gestão. A regulação é feita pelo Conselho Monetário Nacional, órgão

ed. Rio de Janeiro: Lumen Juris, 2001, p. 436.

${ }^{277}$ DI PIETRO, Maria Sylvia Zanella. Parcerias na administração pública. $7^{\mathrm{a}}$ ed. São Paulo: Atlas, 2009, p. 179.

278 ARAGÃO, Alexandre Santos de. Agências reguladoras, e a evolução do direito administrativo econômico. $2^{\mathrm{a}}$ ed. Rio de Janeiro: Forense, 2009, p. 311-329. 
do Ministério da Fazenda, sem personalidade jurídica própria, pois não foi instituído na forma de autarquia. Suas atribuições decorrem de lei e estão previstas principalmente no art. $4^{\circ}$ da Lei $4.595 / 64$.

Ao $\mathrm{CMN}$ cabe não somente estabelecer normas para regulação do sistema bancário como também da área de mercado de capitais. Sobre estes dois setores também exercem regulação, mas em caráter subordinado, o Banco Central e a Comissão de Valores Mobiliários ${ }^{279}(\mathrm{CVM})$, respectivamente. Já os recursos contra atos praticados por seus agentes é julgado, no âmbito administrativo, pelo Conselho de Recursos do Sistema Financeiro Nacional. Portanto, as funções que estariam reunidas em um modelo de agência são repartidas entre estes quatro entes. ${ }^{280}$

Embora a atuação do Banco Central esteja subordinada às Resoluções do CMN, algumas das suas atribuições decorrem da própria Constituição, como a emissão de moeda, manutenção da conta movimento do caixa da União Federal, regulação da oferta de moeda e dos juros mediante negociação de títulos públicos ${ }^{281}$. Já as funções do CMN estão previstas em lei.

${ }^{279}$ A Comissão de Valores Mobiliários foi criada pela Lei 6.385, de 7 de dezembro de 1976, e regula especificamente a área de mercado de capitais e de fundos de investimentos, inclusive fundos de renda fixa por força da Decisão-Conjunta 10 do Banco Central e da CVM, de 02/05/2002, fundada na Lei 10.411/02 e na Lei 10.303/01.

${ }^{280}$ Cabe ressalvar que ainda há outras entidades que atuam, de certo modo, como agências, no mercado financeiro e de capitais, regulando aspectos específicos. Podemos destacar a BM\&FBOVESPA Supervisão de Mercados (BSM), que exerce fiscalização das operações realizadas no âmbito da bolsa de valores; a Câmara Interbancária de Pagamentos (CIP), associação civil sem fins lucrativos com sede na cidade de São Paulo, que coordena o Sistema de Transferência de Fundos (SITRAF) e o Sistema de Liquidação Diferida das Transferências Interbancárias de Ordens de Crédito (SILOC).

${ }^{281}$ CF: “Art. 164. A competência da União para emitir moeda será exercida exclusivamente pelo Banco Central.

$\S 1^{\circ}$ - É vedado ao banco central conceder, direta ou indiretamente, empréstimos ao Tesouro Nacional e a qualquer órgão ou entidade que não seja instituição financeira.

$\S 2^{\circ}$ - O banco central poderá comprar e vender títulos de emissão do Tesouro Nacional, com o objetivo de regular a oferta de moeda ou a taxa de juros.

$\S 3^{\circ}$ - As disponibilidades de caixa da União serão depositadas no banco central; as dos Estados, do Distrito Federal, dos Municípios e dos órgãos ou entidades do Poder Público e das empresas por ele controladas, em instituições financeiras oficiais, ressalvados os casos previstos em lei." 
A autonomia ${ }^{282}$ das agências em grande parte decorre do estabelecimento de um mandato determinado aos administradores. Esta característica gerou certa polêmica, especialmente em razão do poder hierárquico do Chefe do Executivo, de modo que o Supremo Tribunal Federal editou a Súmula 25: "A nomeação a termo não impede a livre demissão, pelo Presidente da República, de ocupante de cargo dirigente de autarquia”. Por outro lado, no julgamento da liminar na ADIN 1949-0, o Plenário do STF suspendeu a eficácia de dispositivo de duas leis estaduais do Rio Grande do Sul ${ }^{283}$ que outorgaram exclusivamente à Assembleia Legislativa a atribuição de destituir dirigentes. Portanto, não há uma unanimidade quanto à autonomia ser um atributo das agências reguladoras.

Ainda que haja alguma divergência quanto a esse atributo, há um certo consenso de que o Banco Central não se enquadra propriamente no conceito de agência reguladora $^{284}$, especialmente pela ausência de autonomia. O presidente e a diretoria, embora indicados pelo Chefe do Executivo ${ }^{285}$ mediante aprovação do Senado ${ }^{286}$, não têm

282 Para Floriano de Azevedo Marques Neto a autonomia, ou independência, "das agências constitui praticamente um elemento de sua definição" (Agências reguladoras independentes, p. 67) e pode ser dividida em duas espécies: orgânica e administrativa. A primeira "se presta para assegurar ampla autonomia no manejo dos instrumentos regulatórios", mediante estabilidade dos dirigentes e ausência de controle hierárquico com a administração direta, enquanto a segunda "envolve dotar a agência da capacidade de organizar e gerir seus orçamentos (claro que observadas as regras gerais de direito financeiro e os mecanismos de controle da gestão pública), alocando os recursos disponíveis nas atividades que, ao ver do órgão, sejam prioritárias e necessárias ao bom exercício de suas atividades" (Agências reguladoras independentes, p. 76).

${ }^{283}$ Lei Estadual 11.292 do Rio Grande do Sul, de 23 de dezembro de 1998: “Art. $8^{\circ}$ O Conselheiro só poderá ser destituído, no curso de seu mandato, por decisão da Assembléia Legislativa”. Lei Estadual 10.931, de 09 de janeiro de 1997: "Art. $8^{\circ}$ Os membros do Conselho Superior da AGERGS somente poderão ser destituídos, no curso de seus mandatos, por decisão da Assembléia Legislativa do Estado”..

${ }^{284}$ MARQUES NETO, Floriano Azevedo. Agências reguladoras independentes, fundamentos e seu regime jurídico. $2^{\mathrm{a}}$ reimpressão. Belo Horizonte: Fórum, 2009, p. 51. JUSTEN FILHO, Marçal. O direito das agências reguladoras independentes. São Paulo: Dialética, 2002, p. 335.

${ }^{285}$ CF: “Art. 84. Compete privativamente ao Presidente da República:

(...)

XIV - nomear, após aprovação pelo Senado Federal, os Ministros do Supremo Tribunal Federal e dos Tribunais Superiores, os Governadores de Territórios, o Procurador-Geral da República, o presidente e os diretores do banco central e outros servidores, quando determinado em lei; (...)".

${ }^{286} \mathrm{CF}$ : “Art. 52. Compete privativamente ao Senado Federal:

(...)

III - aprovar previamente, por voto secreto, após argüição pública, a escolha de:

(...)

d) Presidente e diretores do banco central; (...)." 
mandato fixo e podem ser destituídos a qualquer tempo. ${ }^{287}$ Outra característica do Banco Central é a sua competência normativa, por lei, subordinada ao Conselho Monetário Nacional $^{288}$, pois as Circulares e as Cartas-circulares expedidas destinam-se a dar execução às Resoluções do CMN. Por essas duas características, Alexandre Santos Aragão afirma que "não há como afirmar, ao contrário da tendência verificada na União Européia, que seja autoridade administrativa independente". ${ }^{289}$

Egon Bockmann Moreira igualmente afirma não ser possível admitir a condição de agência reguladora ao $\mathrm{CMN}$ e ao Banco Central, porque "cumprem as determinações da Administração direta", pela liberdade de exoneração dos diretores e conselheiros, pelo "limite decrescente" das atribuições nos "denominados sistema financeiro nacional e mercado mobiliário" e pela ausência do poder de julgar recursos, atribuída ao Conselho de Recursos do Sistema Financeiro Nacional, como segue:

Tendo em vista estas rápidas observações, parece-nos inviável atribuir a tais pessoas administrativas o título de 'agências reguladoras independentes', pois o vínculo funcional e gerencial com a Administração direta impossibilita tal classificação. Em verdade, nem sequer são 'agências administrativas', mas órgãos que se submetem aos tradicionais conceitos de 'desconcentração' (CMN) e ‘descentralização' (BACEN e CVM).

As leis que criaram tais entidades visaram a operacionalizar as diretrizes do Governo federal e conferir agilidade à sua atuação, no que diz respeito à matéria específica a elas outorgada. Porém, não buscaram o verdadeiro conceito contemporâneo de 'agências reguladoras' - que, certamente, vai muito além da desconcentração e descentralização. Os limites dos atributos legalmente conferidos a CMN, BACEN e CVM não possibilitam que sejam qualificados de 'agências administrativas reguladoras'. Caso contrário, o resultado seria duplamente ruinoso: por um lado, a necessidade do conceito de 'agência reguladora' cairia por terra, pois não seria em nada inovador e especial. $\mathrm{O}$

\footnotetext{
287 A Medida Provisória no 207/2004, convertida em Lei 11.036/2004, deu status de ministro de estado ao presidente do Banco Central, mas não alterou as condições para destituição do cargo.

${ }^{288}$ Lei 4595/64: “Art. $9^{\circ}$ Compete ao Banco Central da República do Brasil cumprir e fazer cumprir as disposições que lhe são atribuídas pela legislação em vigor e as normas expedidas pelo Conselho Monetário Nacional".

289 ARAGÃO, Alexandre Santos de. Agências reguladoras, e a evolução do direito administrativo econômico. $2^{\text {a }}$ ed. Rio de Janeiro: Forense, 2009, p. 302.
} 
esforço legislativo desenvolvido nos últimos anos, as definições novidadeiras previstas em lei, a amplitude dos conceitos e competências etc. - tudo isso seria trabalho desnecessário e em vão, pois bastaria eventual nome de batismo e (ou) exercício de fato de determinada atividade administrativa (ainda que num minus em relação à atualmente pretendida), durante certo lapso temporal. Por outro lado, também a razão da lei que definiu CMN, BACEN e CVM seria impertinente e estaria 'vencida', pelo mero passar do tempo. ${ }^{290}$

Outra característica do modelo norte-americano de agências é a exigência de publicidade e participação do cidadão na elaboração e aprovação nas normas editadas mediante procedimento transparente, além de controle parlamentar. ${ }^{291} \mathrm{O}$ sistema de elaboração de regras instituído, em pleno regime militar, pela Lei 4.595/64, não trouxe qualquer previsão nesse sentido. As normas são baixadas pelo CMN e pelo Banco Central sem qualquer necessidade de audiências públicas ou participação do Congresso Nacional, sob o argumento de que as normas são de elevada complexidade, a sua edição por um grupo de técnicos garantiria a neutralidade e a eficiência.

Sendo ou não uma agência reguladora no sentido estrito do termo, o fato é que o Banco Central do Brasil, com o Conselho Monetário Nacional e o Conselho de Recursos do Sistema Financeiro Nacional integram um conjunto destinado a regulamentar a atividade bancária em geral, a partir do modelo de Estado subsidiário que dá condições para o desenvolvimento da atividade econômica sem substituir os particulares e, por conta desta característica, se propõe a editar normas especiais para um mercado específico e dinâmico.

Resta indagar se esse conjunto goza de um status diferenciado de tal modo que justifique estar excluído, total ou parcialmente, do princípio da legalidade.

\footnotetext{
290 MOREIRA, Egon Bockmann. Agências administrativas, poder regulamentar e o sistema financeiro nacional. Revista Eletrônica de Direito Administrativo Econômico (REDAE), Salvador, Instituto Brasileiro de Direito Público, n. 11, agosto/setembro/outubro, 2007. Disponível em: <http://www.direitodoestado.com.br/redae.asp>. Acesso em 17 de dezembro de 2011, p. 8-9.

${ }^{291}$ DI PIETRO, Maria Sylvia Zanella. Parcerias na administração pública. $7^{\mathrm{a}}$ ed. São Paulo: Atlas, 2009, p. 193.
} 


\subsection{Recepção da Lei 4595 pela Constituição Federal e ADCT}

Sob o regime instaurado a partir de $1^{\circ}$ de abril de 1964 , foi editada a Lei de Reforma Bancária, Lei 4595/64, que atribuiu ao Conselho Monetário Nacional e ao Banco Central do Brasil vasta competência normativa em matéria de regulação das atividades bancárias. Destacamos, dentre as atribuições do CMN previstas no art. $4^{\circ}$, as seguintes:

Art. $4^{\circ}$ Compete ao Conselho Monetário Nacional, segundo diretrizes estabelecidas pelo Presidente da República:

VI - Disciplinar o crédito em todas as suas modalidades e as operações creditícias em todas as suas formas, inclusive aceites, avais e prestações de quaisquer garantias por parte das instituições financeiras;

VIII - Regular a constituição, funcionamento e fiscalização dos que exercerem atividades subordinadas a esta lei, bem como a aplicação das penalidades previstas;

XVII - Regulamentar, fixando limites, prazos e outras condições, as operações de redesconto e de empréstimo, efetuadas com quaisquer instituições financeiras públicas e privadas de natureza bancária;

XXXI - Baixar normas que regulem as operações de câmbio, inclusive swaps, fixando limites, taxas, prazos e outras condições.

XXXII - regular os depósitos a prazo de instituições financeiras e demais sociedades autorizadas a funcionar pelo Banco Central do Brasil, inclusive entre aquelas sujeitas ao mesmo controle acionário ou coligadas.

O texto legal não segue o modelo de silogismo normativo básico: diante de $x$ deve ser $y$. Ele não indica ao $\mathrm{CMN}$, por exemplo, o ato administrativo que deve praticar diante da constatação de um determinado fato, mas atribui-lhe o poder de criar normas gerais e abstratas, em verdadeiro regime de delegação legislativa para edição de regulamentos de complementação. ${ }^{292}$

${ }^{292}$ Vide, no Capítulo 2, os conceitos apresentados por Siqueira Castro. 
Por outro lado, a Constituição Federal de 1988, ao traçar as linhas gerais do Sistema Financeiro Nacional, não outorgou ao CMN ou ao Banco Central atribuição de função legislativa, como pode ser observado:

Art. 192. O sistema financeiro nacional, estruturado de forma a promover o desenvolvimento equilibrado do País e a servir aos interesses da coletividade, será regulado em lei complementar, que disporá, inclusive, sobre:

I - a autorização para o funcionamento das instituições financeiras, assegurado às instituições bancárias oficiais e privadas acesso a todos os instrumentos do mercado financeiro bancário, sendo vedada a essas instituições a participação em atividades não previstas na autorização de que trata este inciso;

II - autorização e funcionamento dos estabelecimentos de seguro, previdência e capitalização, bem como do órgão oficial fiscalizador e do órgão oficial ressegurador ${ }^{293}$;

III - as condições para a participação do capital estrangeiro nas instituições a que se referem os incisos anteriores, tendo em vista, especialmente:

a) os interesses nacionais;

b) os acordos internacionais

IV - a organização, o funcionamento e as atribuições do banco central e demais instituições financeiras públicas e privadas;

V - os requisitos para a designação de membros da diretoria do banco central e demais instituições financeiras, bem como seus impedimentos após o exercício do cargo;

VI - a criação de fundo ou seguro, com o objetivo de proteger a economia popular, garantindo créditos, aplicações e depósitos até determinado valor, vedada a participação de recursos da União;

VII - os critérios restritivos da transferência de poupança de regiões com renda inferior à média nacional para outras de maior desenvolvimento;

VIII - o funcionamento das cooperativas de crédito e os requisitos para que possam ter condições de operacionalidade e estruturação próprias das instituições financeiras.

${ }^{293}$ A Emenda Constitucional no 13/1996 deu o seguinte texto ao inciso: "II - autorização e funcionamento dos estabelecimentos de seguro, resseguro, previdência e capitalização, bem como do órgão oficial fiscalizador". 
$\S 1^{\circ}$ - A autorização a que se referem os incisos I e II será inegociável e intransferível, permitida a transmissão do controle da pessoa jurídica titular, e concedida sem ônus, na forma da lei do sistema financeiro nacional, a pessoa jurídica cujos diretores tenham capacidade técnica e reputação ilibada, e que comprove capacidade econômica compatível com o empreendimento.

$\S 2^{\circ}$ - Os recursos financeiros relativos a programas e projetos de caráter regional, de responsabilidade da União, serão depositados em suas instituições regionais de crédito e por elas aplicados.

$\S 3^{\circ}$ - As taxas de juros reais, nelas incluídas comissões e quaisquer outras remunerações direta ou indiretamente referidas à concessão de crédito, não poderão ser superiores a doze por cento ao ano; a cobrança acima deste limite será conceituada como crime de usura, punido, em todas as suas modalidades, nos termos que a lei determinar.

Com a Emenda Constitucional $n^{\circ}$ 40/2003, os dispositivos foram substituídos pela sumária determinação de que o Sistema Financeiro deverá ser regulado por leis complementares a fim de atingir determinados fins econômicos e sociais:

Art. 192. O sistema financeiro nacional, estruturado de forma a promover o desenvolvimento equilibrado do País e a servir aos interesses da coletividade, em todas as partes que o compõem, abrangendo as cooperativas de crédito, será regulado por leis complementares que disporão, inclusive, sobre a participação do capital estrangeiro nas instituições que o integram.

Isso não significa que o Banco Central não tenha recebido atribuições diretas pela Constituição Federal. Pelo contrário, ela trata expressamente sobre os principais mecanismos utilizados para controle da inflação, como a emissão de moeda, negociação de títulos da dívida pública e a conta movimento da União, como segue:

Art. 164. A competência da União para emitir moeda será exercida exclusivamente pelo banco central.

$\S 1^{\circ}$ - É vedado ao banco central conceder, direta ou indiretamente, empréstimos ao Tesouro Nacional e a qualquer órgão ou entidade que não seja instituição financeira. 
$\S 2^{\circ}$ - O banco central poderá comprar e vender títulos de emissão do Tesouro Nacional, com o objetivo de regular a oferta de moeda ou a taxa de juros.

$\S 3^{\circ}$ - As disponibilidades de caixa da União serão depositadas no banco central; as dos Estados, do Distrito Federal, dos Municípios e dos órgãos ou entidades do Poder Público e das empresas por ele controladas, em instituições financeiras oficiais, ressalvados os casos previstos em lei.

Portanto, a Constituição de 1988 tratou do Banco Central e não lhe outorgou a função normativa para edição de decretos autônomos, mesmo que limitados ao âmbito do sistema financeiro nacional. Pelo contrário, declarou que a matéria é de tal importância que deverá ser regulada por "leis complementares". Não há como confundir estas com regulamentos, resoluções, circulares, cartas-circulares, entre outros atos normativos.

Resta verificar se as delegações legislativas do art. $4^{\circ}$ da Lei 4.595/64 permanecem vigentes até a edição das novas leis complementares, de que trata o art. 195 da Constituição. Ocorre que o art. 25 do Ato das Disposições Constitucionais Provisórias revogou todas as delegações ou atribuições de competências por ela declaradas como próprias do Congresso Nacional, especialmente em relação à ação normativa:

Art. 25. Ficam revogados, a partir de cento e oitenta dias da promulgação da Constituição, sujeito este prazo a prorrogação por lei, todos os dispositivos legais que atribuam ou deleguem a órgão do Poder Executivo competência assinalada pela Constituição ao Congresso Nacional, especialmente no que tange a:

I - ação normativa;

II - alocação ou transferência de recursos de qualquer espécie.

Segundo a Constituição Federal, são atribuições do Congresso Nacional e em relação às quais foram revogadas as delegações ou atribuições ao Poder Executivo, as matérias relacionas a operações de crédito e dívida públicas, entre as quais podem ser mencionadas as operações de empréstimos com recursos públicos, além de operações bancárias e câmbio: 
Art. 48. Cabe ao Congresso Nacional, com a sanção do Presidente da República, não exigida esta para o especificado nos arts. 49, 51 e 52, dispor sobre todas as matérias de competência da União, especialmente sobre:

II - plano plurianual, diretrizes orçamentárias, orçamento anual, operações de crédito, dívida pública e emissões de curso forçado;

XIII - matéria financeira, cambial e monetária, instituições financeiras e suas operações;

XIV - moeda, seus limites de emissão, e montante da dívida mobiliária federal.

Portanto, houve revogação dos dispositivos legais que davam competência normativa ao CMN e ao Banco Central, salvo se uma lei, antes desta revogação, prorrogasse o prazo de vigência da delegação, como leciona Maria Sylvia Zanella Di Pietro:

Certo é que alguns desses órgãos podem baixar atos normativos com base no art. 25 do Ato das Disposições Constitucionais Transitórias, desde que tenham recebido essa competência antes da Constituição de 1988 e o prazo para vigência das leis que fizeram a delegação tenha sido prorrogado, conforme previsto nesse dispositivo. A competência, nesses casos, há de ser exercida nos limites em que foi delegada por lei. Fora desses casos, as normas têm que se limitar a aspectos puramente técnicos, não definidos pelo legislador e que não alterem o alcance da lei, ou têm que ter efeito exclusivamente interno, limitado ao próprio âmbito do órgão, sob pena de inconstitucionalidade, por infringência ao princípio da legalidade e invasão em área reservada ao legislador. ${ }^{294}$

Assim, a Lei 8.056/90 declarou a prorrogação da vigência dos dispositivos da Lei 4595/64:

Art. $1^{\circ}$ É prorrogada, até o dia 31 de dezembro de 1990, a vigência dos dispositivos legais que hajam atribuído ou delegado, ao Conselho Monetário Nacional e ao Conselho Nacional de Seguros Privados, competências assinaladas, pela Constituição, ao Congresso Nacional.

${ }^{294}$ DI PIETRO, Maria Sylvia Zanella. Parcerias na administração pública. $7^{\mathrm{a}}$ ed. São Paulo: Atlas, 2009p. 143-144. 
Ocorre que a Lei 8.056/90 somente foi promulgada mais de um ano após a revogação constitucional, e o texto do ADCT menciona prorrogação por lei e não por outro ato com força de lei (medida provisória e lei delegada, por exemplo).

Assim, como não é possível prorrogar algo que já foi revogado, a Lei 8.056/64 consiste em "nova delegação legislativa, o que seria inconstitucional na nova ordem, que veda a delegação". ${ }^{295}$

Por outro lado, alguns autores defendem que a Medida Provisória 45, de 31/03/1989 296 , supriu a ausência de lei, embora somente tenha sido convertida após o período de 180 dias, como é o caso de Egon Bockmann Moreira:

Por fim, merece análise o óbice do art. 25 do ADCT, que estabeleceu o prazo de 180 dias para vigência de 'todos os dispositivos legais que atribuam ou deleguem a órgão do Poder Executivo competência assinalada pela Constituição ao Congresso Nacional' - depois do qual tais normas estariam revogadas.

Depois de sucessão de leis pertinentes à competência do Conselho Monetário Nacional, o art. 73 da Lei 9.069, de 29.6.95 dispôs que o art. $1^{\text { }}$ da Lei 8.392/91 passaria a dispor sobre a prorrogação 'até a data da promulgação da lei complementar de que trata o art. 192 da Constituição Federal o prazo a que se refere o art. $1^{\circ}$ das Leis $n^{\circ} 8.056$, de 28 de junho de 1990, $\mathrm{n}^{\circ} 8.201$, de 29 de junho de 1991, exceto no que se refere ao disposto nos arts. $4^{\circ}$, inciso $\mathrm{I}, 6^{\circ}$ e $7^{\circ}$, todos da Lei 4.595, de 31 de dezembro de 1964.'

No que tange a tais entidades, não incide a revogação emanada do ADCT. ${ }^{297}$

\footnotetext{
295 ROCHA, Jean Paul Cabral Veiga da. A capacidade normativa de conjuntura no direito econômico: o déficit democrático da regulação financeira. Tese (Doutorado), Universidade de São Paulo, São Paulo, 2004, p. 16.

${ }^{296}$ Art. $1^{\text {o }}$ Fica prorrogada, até 30 de abril de 1990, a vigência dos dispositivos legais que hajam atribuído ou delegado ao Conselho Monetário Nacional, ao Conselho Nacional do Comércio Exterior, ao Conselho Nacional de Seguros Privados e ao Conselho Interministerial de Preços, competências assinaladas, pela Constituição, ao Congresso Nacional.

Art. $2^{\circ}$ Esta Medida Provisória entra em vigor na data de sua publicação.

297 MOREIRA, Egon Bockmann. Agências administrativas, poder regulamentar e o sistema financeiro nacional. Revista Eletrônica de Direito Administrativo Econômico (REDAE), Salvador, Instituto Brasileiro de Direito Público, n. 11, agosto/setembro/outubro, 2007. Disponível em: <http://www.direitodoestado.com.br/redae.asp>. Acesso em 17 de dezembro de 2011, , p. 19.
} 
A questão ainda não foi apreciada pelo Supremo Tribunal Federal, sendo que em duas oportunidades não houve enfrentamento direto em virtude de outras circunstâncias específicas da matéria em julgamento. ${ }^{298}$

Nosso entendimento é no sentido de que somente por lei ordinária, editada dentro do prazo de 180 dias, poderiam ser mantidas as delegações legislativas outorgadas pela Lei 4595/64. O Constituinte originário permitiu, em caráter de excepcionalidade, a manutenção de delegações anteriores à promulgação da Constituição. Considerando que a delegação legislativa, em princípio, é um ato próprio de um órgão legislativo, a sua confirmação somente poderia se dar por outro ato igualmente emanado do órgão legislativo.

No direito predomina a lógica segundo a qual somente quem atribui poderes pode confirmá-los ou prorrogá-los. É a lógica pela qual somente quem outorga uma procuração pode confirmar ou prorrogar o ato. Não faz sentido, portanto, o outorgado - no caso o Poder Executivo - praticar um ato (edição de medida provisória) para ampliar seus próprios poderes. Como a manifestação do Poder Legislativo em relação à MP 45/89 somente ocorreu fora do prazo, não restam dúvidas de que esta deixou de produziu os efeitos jurídicos almejados.

\subsection{Teorias sobre o poder regulatório do CMN e BACEN}

A questão referente ao poder regulatório do Conselho Monetário Nacional e do Banco Central está inserida em um debate mais amplo, sobre os limites do poder normativo que não é exercido pelo Poder Legislativo.

O tema assume uma feição especial em razão dos estreitos espaços conferidos pela Constituição Federal e, de outro lado, pela necessidade de intervenções rápidas em setores da economia muito especializados, de grande relevância e que demandam um profundo conhecimento da atividade realizada.

${ }^{298}$ RE 286963 / MG - Minas Gerais, Recurso Extraordinário, Relator: Min. Sepúlveda Pertence, Julgamento: 24/05/2005, Órgão Julgador: Primeira Turma; RE 255373 AgR / MG - Minas Gerais - Ag.Reg.No Recurso Extraordinário, Relator: Min. Nelson Jobim, Julgamento: 29/08/2000, Órgão Julgador: Segunda Turma. 
Muitos autores buscam justificar um poder mais amplo que o previsto no texto constitucional, sendo que estas ideias podem ser agrupadas em quatro: (i) atividade bancária como concessão de serviço público, defendida no Brasil principalmente por Arnoldo Wald; (ii) a ocorrência de mudança de paradigmas, aqui demonstrada por Tércio Sampaio Ferraz Júnior; (iii) a do poder normativo de conjuntura, encontrada na obra de Eros Grau, e (iv) de sujeição jurídica especial defendida por Celso Antônio Bandeira de Mello.

\subsubsection{Atividade bancária como concessão de serviço público - Arnoldo Wald}

A ideia de que os bancos exercem um serviço público concedido tem como eixo o conceito de moeda escritural, sendo que a emissão de moeda e seu controle são uma atividade tipicamente estatal.

Os economistas observaram que, se uma pessoa efetivasse o depósito de $\$ 10,000,00$, receberia em contrapartida um certificado ao portador que permitiria que qualquer pessoa que estivesse em poder deste título pudesse exigir o pagamento à vista pelo banco mediante sua apresentação. Esses certificados, por serem amplamente aceitos, eram utilizados como forma de pagamento de obrigações em geral tal como se faz uso de uma cédula.

Por outro lado, o banco, ao receber este depósito, buscava emprestar o dinheiro a fim de obter remuneração por cobrança de juros. Então o valor retornava à circulação no mercado em virtude do empréstimo. Ao final dessas duas operações, o total de moeda em circulação dobrou, de $\$ 10.0000,00$ para $\$ 20.000,00$.

Os bancos têm como principal atividade a captação de dinheiro do público em geral. O certificado de depósito ao portador (utilizado antigamente) ou o atual registro de saldo credor em conta de depósitos passaram a ser reconhecidos como forma de quitação de obrigações. Por outro lado, o banco utiliza o volume de dinheiro depositado para empréstimos a juros, de modo que o dinheiro retorna ao mercado na forma de moeda. Este, por sua vez, quando depositado em banco, gera novamente o mesmo fenômeno. 
Essa função multiplicadora da moeda circulante pela atividade bancária é sintetizada por Arnoldo Wald, como se observa:

Verificamos, assim, que, na realidade, os bancos comerciais criam moeda, exercendo verdadeira ação multiplicadora da função emissora do Banco Central. Desse modo, podemos até afirmar que, enquanto o Banco Central é o órgão emissor por atacado, os bancos comerciais são os multiplicadores da moeda que a redistribuem a varejo. Assim, ao princípio do tradicional deposit make loans, acrescentou-se a sua inversão loans make deposits. ${ }^{299}$

A geração de moeda escritural passou a ser controlada e fiscalizada pelo Estado moderno com a monopolização da emissão do papel moeda. São criados diversos mecanismos de restrição à criação de excesso de moeda escritural e de garantia da solvência dos bancos, principalmente por meio de depósito compulsório pelos bancos em contas de reservas do Banco Central.

Surge então a ideia de que o Banco Central, por estes mecanismos de controle, ora restringindo, ora permitindo, pratica uma concessão imprópria de emissão de moeda, na forma escritural, pelas instituições financeiras.

Arnoldo Wald noticia que a conceituação desse regime de delegação do poder estatal foi amplamente discutida na Europa, com mais ênfase na Itália e na França, sendo que alguns autores franceses, entre os quais Roger Houin, definiram a instituição financeira como sendo "o instrumento de um serviço de distribuição e regulação do crédito, considerando que estaria exercendo 'um verdadeiro serviço público' ou, ainda, que a 'função bancária é próxima do serviço público"'. 300

Arnoldo Wald defende a ideia de concessão de serviço público de emissão de moeda pelo Banco Central aos bancos privados, como segue:

\footnotetext{
${ }^{299}$ WALD, Arnoldo. O direito da regulação monetária e bancária. Revista de Direito Bancário, do mercado de capitais e da arbitragem, n. 17, São Paulo, julho-setembro 2002, p. 23.

${ }^{300}$ WALD, Arnoldo. O direito da regulação monetária e bancária. Revista de Direito Bancário, do mercado de capitais e da arbitragem, n. 17, São Paulo, julho-setembro 2002, p. 25.
} 
O sistema bancário como um todo, abrangendo tanto o Banco Central como a totalidade dos bancos comerciais que recebem depósitos à vista, além de outras instituições, constitui, pois, uma unidade orgânica, um sistema, que tem uma verdadeira função de serviço público incumbido do exercício do poder monetário, que, na realidade, é um poder-dever. ${ }^{301}$

O autor chega à conclusão de que a atividade bancária no Brasil somente pode ser regulada por normas baixadas pelo Conselho Monetário Nacional e que somente podem ser alteradas por suas próprias decisões ou "em virtude do desaparecimento ou da redução parcial de sua competência". Assim, essas Resoluções do CMN, "baseadas em lei complementar, não podem ser alteradas por lei ordinária, mas não lhes é dado produzir efeitos fora da sua competência específica". 302

A ideia de que esta forma imprópria de concessão seria fundamento para a autonomia quase legislativa do Banco Central e do Conselho Monetário Nacional deixa algumas questões em aberto.

Além da atividade de intermediação financeira, captação e empréstimos, há diversas outras atividades econômicas que não implicam em emissão de moeda escritural. A compensação de cheques, a cobrança de títulos, a administração de patrimônio de terceiros organizado na forma de fundos de investimentos, são alguns exemplos. $^{303}$

Há várias normas que buscam padronizar os serviços e permitir maior solidez e transparência das instituições financeiras, como aquelas que tratam da composição dos cargos de administração das instituições financeiras e dos tipos de contas que podem ser oferecidas. Outras normas do CMN simplesmente se destinam a permitir

\footnotetext{
${ }^{301}$ WALD, Arnoldo. O direito da regulação monetária e bancária. Revista de Direito Bancário, do mercado de capitais e da arbitragem, n. 17, São Paulo, julho-setembro 2002, p. 24.

${ }^{302}$ WALD, Arnoldo. O direito da regulação monetária e bancária. Revista de Direito Bancário, do mercado de capitais e da arbitragem, n. 17, São Paulo, julho-setembro 2002, p. 28.

303 Por disposição da Lei 10.303/2001 e da Lei 10.411/2002, a regulação e a fiscalização dos fundos de investimento em renda fixa, até então atribuídas ao Conselho Monetário Nacional e ao Banco Central, passaram a ser atribuições da Comissão de Valores Mobiliários.
} 
maior ingresso de receita nos cofres públicos, mediante fixação de limites mínimos de títulos públicos na composição da carteira de fundos de investimento.

Se realmente o fundamento da regulação do sistema financeiro fosse a concessão de emissão da moeda, não haveria fundamento para o CMN e o Banco Central regularem todos os demais aspectos da atividade bancária diversos da fixação dos valores do recolhimento compulsório dos bancos.

Outra questão é a dificuldade de se qualificar a emissão de moeda escritural como serviço público no sentido próprio do termo.

Como leciona Dinorá Adelaide Musetti Grotti, a noção de serviço público não é algo imutável, variando ao longo do tempo e espaço, dependendo de escolhas políticas em cada situação, "disto deflui que não há um serviço público por natureza ou por essência". ${ }^{304}$ Diante desse entendimento predominante de ausência de um critério material para sua identificação, Maria Sylvia Zanella Di Pietro o define como "toda a atividade material que a lei atribui ao Estado para que exerça diretamente ou por meio de seus delegados, com o objetivo de satisfazer concretamente às necessidades coletivas, sob regime jurídico total ou parcialmente público". 305

A denominada moeda escritural não consiste propriamente na atividade material de emissão de moeda. Trata-se de um termo econômico para designar a utilização da cessão de créditos para solver obrigações. Quando um indivíduo utiliza o saldo de sua conta corrente para o pagamento de uma fatura mensal de consumo de energia elétrica, por exemplo, ele não está quitando uma dívida mediante pagamento em moeda corrente, mas por cessão de um crédito que detém com o banco. A instituição financeira não cria moeda, mas sim créditos que podem ser cedidos, assim como em qualquer situação em que houver transferência de créditos entre particulares.

${ }^{304}$ GROTTI, Dinorá Adelaide Musetti. O serviço público e a constituição brasileira de 1988. São Paulo: Malheiros, 2003, p. 88.

${ }^{305}$ DI PIETRO, Maria Sylvia Zanella. Direito administrativo. 23 ${ }^{a}$ ed. São Paulo: Atlas, 2010, p. 102. 
Aqui não se confunde emissão de moeda com os meios próprios para tal. A impressão ou cunhagem são executadas pela Casa da Moeda, atividade que poderia ser executada por qualquer outra gráfica com tecnologia adequada. As cédulas e as moedas metálicas são distribuídas pelos bancos e casas lotéricas.

Emissão de moeda é a colocação no mercado de meios de pagamento assim declarados pelo Estado como hábeis para solver qualquer obrigação, seja por meio de bens corpóreos ou ainda eletrônicos. Nada impede que seja criada pelo Banco Central uma forma de moeda eletrônica a que a lei confira poderes de solver qualquer obrigação. Esta forma de emissão de moeda não se confunde com o registro de crédito à vista em um banco, ainda que estatal.

Portanto, a emissão de moeda não é propriamente uma prestação de serviço material para satisfação de necessidades coletivas concretas.

A Constituição Federal também não propicia condições para afirmar que a atividade bancária é um serviço público concedido pelo Estado. O artigo 192, com redação determinada pela Emenda Constitucional n 40/2003, não qualifica como atividade exclusiva do Estado, serviço público ou outra situação para a qual exista um regime de outorga de poderes para sua execução, como segue:

Art. 192. O sistema financeiro nacional, estruturado de forma a promover o desenvolvimento equilibrado do País e a servir aos interesses da coletividade, em todas as partes que o compõem, abrangendo as cooperativas de crédito, será regulado por leis complementares que disporão, inclusive, sobre a participação do capital estrangeiro nas instituições que o integram.

Cabe ainda mencionar a crítica de Sidnei Turczyn com base na ideia de "crise da noção de serviço público" proposta por José Maria Morenilla. Esta crise decorreria da impossibilidade de se definir a priori o que seria um serviço público e, portanto, delimitar seu conceito. ${ }^{306}$ Assim, não haveria como responder à indagação

${ }^{306}$ Essa seria "gerada fundamentalmente pela perda da especificidade do serviço público decorrente de sua
confusão com o privado, pela utilização ampla de seu conceito e pela ambigüidade de seus termos e das 
sobre a atividade bancária ser serviço público de forma absoluta, a fim de se justificar a regulação do Estado na atividade bancária, "pelo simples fato de se reconhecer interesse público e indispensabilidade a essa atividade". 307

Portanto, ainda que previstos em lei determinados requisitos para autorização de funcionamento de instituições financeiras, seguradoras, previdência e de capitalização, carece de fundamentos a tese da utilização da concessão para justificar um regime de sujeição especial e, portanto, o poder regulador do CMN e do Banco Central, com força de lei.

\subsubsection{Mutação Constitucional - Tércio Sampaio Ferraz Júnior}

Tércio Sampaio Ferraz Júnior parte da ideia de que as funções de controle normativo e regulador exigem do Estado maior flexibilização na gestão de serviços públicos em sentido amplo. Neste contexto foi inserido no art. 37 da Constituição Federal o princípio da eficiência.

Para o autor, o princípio da eficiência significa que a atuação da Administração deve se pautar por resultados e não por meios. A Administração, diante do mercado a ser regulado, deve ser dotada de "competências reguladoras de natureza técnica e especializada sob pena de paralisia". Para tanto, não deve adotar medidas previamente previstas em lei, mas deve ter o poder para "alocar fins específicos e encontrar meios correspondentes".

Assim, o modelo burocrático, segundo o qual a Administração deve executar os comandos legais, é substituído por outro, para o qual a lei deve determinar os fins a serem atingidos, cabendo ao administrador pautar sua atuação de acordo com os critérios técnicos mais adequados, norteados pela lei.

construções doutrinárias". TURCZYN, Sidnei. O Sistema Financeiro Nacional e a regulação bancária. São Paulo: RT, 2005, p. 285.

307 TURCZYN, Sidnei. O Sistema Financeiro Nacional e a regulação bancária. São Paulo: RT, 2005, p. 286. 
Assim, o autor propõe um novo critério de validade da norma, com base no juízo de finalidade, que denomina finalístico, sem excluir o tradicional critério condicional, segundo o qual uma norma é válida se estiver em conformidade com as condições que estabelecem a norma superior, como segue:

Uma norma valida outra, condicionalmente, se preestabelece condições que devem ser respeitadas e nestas condições localiza a validade da norma subseqüente, independentemente se os fins normativos são ou não atingidos. Por exemplo, uma norma constitucional que impõe uma vedação (proibição de instituir tributo que não seja uniforme) valida normas legais que estatuam tributações, se respeitada a vedação, independente de se os fins (provimento de recursos adequados às necessidades) estão ou não sendo alcançados.

Já uma norma valida outra, finalisticamente, se preestabelece fins que devam ser alcançados, devendo ser encontrados os meios adequados. Neste caso, a validade da norma subseqüente localiza-se na solidariedade entre fins e meios, donde a questão da validade levantar problemas de proporcionalidade, razoabilidade, adequação etc. Por exemplo, é o caso de uma norma constitucional que preestabeleça o regime legal para concessões e permissões e nele o respeito aos direitos dos usuários, política tarifária e obrigação de manter serviço adequado. Neste caso a validade constitucional da norma legal exige respeito à solidariedade de meios e fins. ${ }^{308}$

Segundo este novo modelo, a lei concede ao agente público atribuição de praticar atos que atinjam os efeitos jurídicos determinados "pelas necessidades do serviço considerado, necessidades que, porque previstas pelo legislador, são as únicas que podem determinar o agente". 309

Em acréscimo aos três tipos de delegação legislativa (segundo o modelo proposto por Carlos Roberto de Siqueira Castro que apresentamos no item 2.3), Tércio Sampaio Ferraz Júnior propõe um quarto, que denomina delegação instrumental.

308 FERRAZ JÚNIOR, Tércio Sampaio. Agências reguladoras: legalidade e discricionariedade. Texto disponível em: <http://www.bresserpereira.org.br/documents/mare/Agencias/AgenciasReguladoras.PDF>. Acesso em 27 de novembro de 2011, p. 13.

309 FERRAZ JÚNIOR, Tércio Sampaio. Agências reguladoras: legalidade e discricionariedade. Texto disponível em: <http://www.bresserpereira.org.br/documents/mare/Agencias/AgenciasReguladoras.PDF>. Acesso em 27 de novembro de 2011, p. 15. 
Este não consiste na definição de objetivos genéricos, mas na enunciação legal de três "funções" que devem estar simultaneamente explícitas em lei, sem o que a delegação carecerá de eficácia plena, como segue:

Em primeiro lugar, normas visam a impedir ou cercear a ocorrência de comportamentos. Esta função tem o sentido de bloqueio de condutas indesejáveis (função de bloqueio). Em segundo lugar, normas visam à consecução de um objetivo, que funciona como um telos programático (função programática). Por fim, normas visam a assegurar um comportamento (função de resguardo).

A delegação instrumental tem a ver com os casos de eficácia limitada da lei, em que preponderam as funções programáticas e de resguardo. Trata-se de situações em que, por razões de complexidade setorial e de correspondente exigência de especialização técnica, a lei que atribui a delegação autoriza decisões de mérito, responsabilizando-se o órgão competente pela alocação de fins tecnicamente apropriados e pelo encontro do meio correto. Esta responsabilidade é avaliada pela eficiência da medida. A lei traça as políticas setoriais, decidindo sobre as macro-alternativas, indica os meios gerais (função de resguardo) e, para o detalhamento de fins e meios, exige a atividade delegada (função programática). ${ }^{310}$

Especificamente em relação ao Banco Central, o autor não chega a concluir se o texto da Lei 4.595/64 contém as três funções legitimadoras da delegação instrumental, mas afirma que se trata de uma autarquia especial e que suas atribuições decorrem especificamente da Constituição e da lei, como segue:

Há ademais caso de autarquia especial, criada antes do advento da figura agência, cujas atribuições decorrem diretamente da Constituição Federal e da lei complementar nela prevista, cujos dirigentes não têm mandato, mas que goza de outras formas de independência, sem, por isso, ser chamada de

${ }^{310}$ FERRAZ JÚNIOR, Tércio Sampaio. Agências reguladoras: legalidade e discricionariedade. Texto disponível em: <http://www.bresserpereira.org.br/documents/mare/Agencias/AgenciasReguladoras.PDF>. Acesso em 27 de novembro de 2011, p. 16. 
agência: o Banco Central. ${ }^{311}$

De fato, há de se considerar que o princípio da eficiência, inserido no art. 37, caput, da Constituição Federal pela Emenda Constitucional nº 19/98, não pode ser desconsiderado em absoluto. Entretanto, não pode ser justificativa para a exclusão de outros princípios como o da legalidade, como afirma Celso Antônio Bandeira de Mello, "pois jamais uma suposta busca de eficiência justificaria postergação daquele que é o dever administrativo por excelência". 312

Maria Sylvia Zanella Di Pietro também critica a ideia de afastar a legalidade em prol de uma eficiência, fora do estrito âmbito da relação jurídica entre agência reguladora e o concessionário de serviço público:

$O$ que as agências não podem fazer, porque falta $o$ indispensável fundamento constitucional, é baixar regras de conduta, unilateralmente, inovando na ordem jurídica, afetando direitos individuais, substituindo-se ao legislador. Esse óbice constitui-se no mínimo indispensável para preservar o princípio da legalidade e o princípio da segurança jurídica. Principalmente, não podem as agências baixar normas que afetem os direitos individuais, impondo deveres, obrigações, penalidades, ou mesmo outorgando benefícios, sem previsão em lei. Trata-se de matéria de reserva de lei, consoante decorre do artigo $5^{\circ}$, II, da Constituição.

Mesmo para as que têm fundamento constitucional, a competência reguladora tem que se limitar aos chamados regulamentos administrativos ou de organização, referidos no item 8.3.1, só podendo dizer respeito às relações entre os particulares que estão em situação de sujeição especial ao Estado. No caso da Anatel e da ANP as matérias que podem ser por elas reguladas são exclusivamente as que dizem respeito aos respectivos contratos de concessão, observados os parâmetros e princípios estabelecidos

\footnotetext{
${ }^{311}$ FERRAZ JÚNIOR, Tércio Sampaio. Agências reguladoras: legalidade e discricionariedade. Texto disponível em: <http://www.bresserpereira.org.br/documents/mare/Agencias/AgenciasReguladoras.PDF>. Acesso em 27 de novembro de 2011, p. 19.

312 BANDEIRA DE MELLO, Celso Antônio. Curso de direito administrativo. $28^{\mathrm{a}}$ ed. São Paulo: Malheiros, 2011, p. 122.
} 
em lei. ${ }^{313}$

Ainda assim, Tércio Sampaio Ferraz Júnior reconhece a impossibilidade de a Administração instituir sanções por haver expressa previsão na Constituição de que se trata de matéria de lei formal, como segue:

Assim, por exemplo, embora no passado, à luz da constituição anterior, fosse possível sustentar que a imposição de penas administrativas pudesse resultar de regulamentos, na Constituição vigente trata-se de expressa competência do Congresso (art. 48 caput, cc. art. 24 - I). ${ }^{314}$

Assim, ausente uma relação contratual, entre a Administração e o particular, da qual derivem obrigações específicas, que podem ser de meio ou de resultado, não há como serem criadas quaisquer restrições às liberdades, especialmente por imposição de sanções administrativas com a expressa previsão do tipo em lei.

\subsubsection{Regulamentos autorizados e autônomos - Eros Grau}

Eros Roberto Grau afirma que o poder regulamentar não decorre de delegação legislativa, mas de uma "permissão para o exercício de função que é própria do Executivo, como faculdade vocacionada à integração do ordenamento jurídico"315, partindo da distinção entre função normativa e função legislativa, com base em Renato Alessi.

Este defende que a função legislativa, em um sistema de partição de poderes, é confiada a determinados órgãos, que integram o Poder Legislativo, aos quais é confiada a tarefa de emanar estatuições primárias, ou seja, que são impostas por

\footnotetext{
${ }^{313}$ DI PIETRO, Maria Sylvia Zanella. Parcerias na administração pública. $7^{\text {a }}$ ed. São Paulo: Atlas, 2009, p. 147.

${ }^{314}$ FERRAZ JÚNIOR, Tércio Sampaio. Agências reguladoras: legalidade e discricionariedade. Texto disponível em: <http://www.bresserpereira.org.br/documents/mare/Agencias/AgenciasReguladoras.PDF>. Acesso em 27 de novembro de 2011, p. 4.

${ }^{315}$ GRAU, Eros Roberto. O direito posto e o direito pressuposto. $8^{\text {a }}$ ed. São Paulo: Malheiros, 2011, p. 245.
} 
forças próprias. Mesmo leis apenas em sentido formal emanadas do Legislativo são estatuições primárias $^{316}$, ainda que não tenham conteúdo normativo. ${ }^{317}$

Neste contexto, entende-se como função normativa a de "emanar estatuições primárias, seja em decorrência do exercício do poder originário para tanto, seja em decorrência de poder derivado, contendo preceitos abstratos e genéricos". 318

Eros Roberto Grau defende que o fundamento do poder regulamentar assenta-se sobre uma atribuição de poder normativo contida explícita ou implicitamente na Constituição ou em uma lei formal, como segue:

O fundamento do poder regulamentar, pois, está nesta atribuição de poder normativo - e não no poder discricionário da Administração (como, equivocadissimamente, apregoam nossos publicistas). Assim, o fundamento da potestade regulamentar decorre de uma atribuição de potestade normativa material, de parte do Legislativo, ao Executivo. E conclui Alessi [1978/458]: 'attribuzione da tenersi naturalmente ben distinta dalla delega di potestà legislativa formale', Tal atribuição - completa - não há de ser necessariamente explícita, surgindo, por vezes, de modo implícito.

O que importa reter, neste passo, é o fato de que o exercício da função regulamentar, pelo Executivo, não decorre de uma delegação de função legislativa. $^{319}$

Assim, Eros Grau propõe a existência de três tipos de regulamentos no direito brasileiro: (i) regulamentos de execução, para desenvolvimento da lei com a

\footnotetext{
${ }^{316}$ Este conceito de primariedade não se confunde com o de originalidade. A primeira está relacionada à legitimidade para se impor e a segunda refere-se à inovação, ou seja, instauração originária de uma obrigação no ordenamento jurídico. Este último critério é defendido por Celso Antônio Bandeira de Mello, como segue: "a função do ato administrativo só poderá ser a de agregar à lei nível de concreção; nunca lhe assistirá instaurar originariamente qualquer cerceio a direitos de terceiros" (Curso de direito administrativo, p. 103).

${ }^{317}$ GRAU, Eros Roberto. O direito posto e o direito pressuposto. $8^{\text {a }}$ ed. São Paulo: Malheiros, 2011, p. 236237.

${ }^{318}$ GRAU, Eros Roberto. O direito posto e o direito pressuposto. $8^{\text {a }}$ ed. São Paulo: Malheiros, 2011, p. 238. Grifos no original.

${ }^{319}$ GRAU, Eros Roberto. O direito posto e o direito pressuposto. $8^{\text {a }}$ ed. São Paulo: Malheiros, 2011, p. 239. Grifos no original.
} 
dedução do seu conteúdo, independentemente de disposição que autorize; (ii) regulamentos autorizados, "emanados a partir de atribuição explícita do exercício da função normativa do executivo", como a alteração de alíquotas dos impostos sobre importação, exportação, produtos industrializados e operações financeiras, por disposição expressa do art. $153, \S 1^{\circ}$ da Constituição Federal; e (iii) regulamentos autônomos ou independentes, "emanados a partir da atribuição implícita do exercício de função normativa ao Executivo, definida no texto constitucional ou decorrente de sua estrutura". 320

O princípio da legalidade declarado no art. $5^{\circ}$, inciso II da Constituição deve ser considerado em "termos relativos apenas", "o que induz à conclusão de que o devido acatamento lhe estará sendo conferido quando - manifesta, explícita ou implicitamente, atribuição para tanto - ato normativo não legislativo, porém regulamentar (ou regimental), definir obrigação de fazer ou não fazer alguma coisa imposta a seus destinatários”. Assim, somente haveria reserva de lei para definição de crime ou pena, para cobrar tributo e para limitar o exercício de atividade econômica condicionando-o à exigência de autorização de órgão público.

Sob estes fundamentos, o Banco Central do Brasil estaria perfeitamente investido de poder regulamentar para dispor sobre qualquer matéria prevista na Lei 4595/64 e alterações que vier a sofrer, razão pela qual Eros Grau critica a visão do que chama de doutrina tradicional, como segue:

O exercício da capacidade normativa de conjuntura estaria, desde a visualização superficial dos arautos da 'separação' de poderes, atribuído ao Poder Legislativo, não ao Poder Executivo. A doutrina brasileira tradicional do direito administrativo, isolando-se da realidade, olimpicamente ignora que um conjunto de elementos de índole técnica, aliado a motivações de premência e celeridade na conformação do regime a que se subordina a atividade de intermediação financeira, tornam o procedimento legislativo, com seus prazos e debates prolongados, inadequado a ordenação de matérias essencialmente conjunturais. No que tange ao dinamismo do sistema

${ }^{320}$ GRAU, Eros Roberto. O direito posto e o direito pressuposto. $8^{\mathrm{a}}$ ed. São Paulo: Malheiros, 2011, p. $247-$ 48. 
financeiro, desconhece que o caráter instrumental da atuação de seus agentes, e dele próprio, desenha uma porção da realidade à qual não se pode mais amoldar o quanto as teorias jurídicas do século passado explicavam. Por isso não estão habilitados, os seus adeptos, a compreender o particular regime de direito a que se submete o segmento da atividade econômica envolvido com a intermediação financeira. Não é estranho, assim, que essa doutrina - no mundo irreal em que se afaga - não avance um milímetro além da afirmação, por exemplo, de que todas as resoluções do Conselho Monetário Nacional, editadas pelo Banco Central do Brasil, são inconstitucionais!

Floriano de Azevedo Marques Neto reforça esta linha apresentada por Eros Grau, destacando a impossibilidade de o legislador esgotar as normas sobre matérias submetidas a agências reguladoras e a própria razão de existência das agências reguladoras:

Deveras, na medida em que se coloca intrínseco ao órgão regulador o exercício de uma forte atividade regulamentadora, interconectada com as especificidades e complexidades próprias ao âmbito de sua regulação, advém a incompatibilidade desta atividade com o pressuposto de vinculação estrita da atividade administrativa à lei. A incompatibilidade exposta aqui com relação à legalidade decorre, justamente, do caráter de mediação e de articulação que os órgãos reguladores cumprem em face dos diversos interesses públicos enredados em sua atividade. Disso advém uma enorme dificuldade em operar dentro dos padrões rígidos e hierarquizados do positivismo jurídico e do cânone da legalidade, centrais ao paradigma até então vigente. Daí Sabino Cassese observar que as autoridades independentes não perdem seu caráter de legitimidade, estando subordinadas não ao princípio da legalidade, mas apenas à règle de droit, $\mathrm{O}$ fato é que a atuação destes órgãos reguladores reflete a crise vivida pelo princípio da legalidade, crise esta que não decorre meramente do fenômeno do surgimento das agências, mas da própria profusão de fontes normativas. Aqui parece se colocar a chave para superar a crítica, sempre presente, relativa à suposta contraposição entre a nova regulação estatal e o princípio da legalidade. A oposição não está entre as competências e funções das agências e a figura da lei como fonte necessária das competências do agente 
público. O que parece estar em questão é a motriz da legalidade. Ou seja: o tipo de prescrição que deverá estar contida no comando legal. Presente parece estar a inviabilidade de se pretender que o princípio da legalidade imponha que a norma legal deva trazer, precisamente, o conteúdo, a forma, a oportunidade e a ocasião do exercício da atividade regulatória. Em crise está, não o princípio da legalidade, mas o conteúdo totalizador da prescrição legal. Daí por que assistimos ao advento de uma nova motriz normativa, marcada pelo surgimento do que Eros Grau denomina por 'normas objetivo'. A relação das agências reguladoras com o Direito se dá em face de uma nova legalidade: a lei define as metas principais e os contornos da atividade do órgão regulador, cometendo-lhe (nestes limites e sob controle do judiciário e do próprio Legislativo) ampla margem de atuação. Atuação esta que segue um novo tipo de discricionariedade, pautado fundamentalmente pelos objetivos definidos na Lei para serem implementados no setor regulador. $^{321}$

Celso Antônio Bandeira de Mello, por outro lado, afirma que o art. $5^{\circ}$, inciso II da Constituição Federal, "não diz decreto, não diz regulamento, não diz instrução normativa, mas simplesmente lei”. Segundo o autor, "segue-se que, em face dele, qualquer ato da Administração só pode obrigar quando seja mera concretização de um abstrato comando legal", 322

A nosso ver, a melhor interpretação para o princípio da legalidade é que o Constituinte, a fim de marcar o momento de ruptura com o regime ditatorial militar, optou por enunciar o princípio da legalidade de forma ampla no art. $5^{\circ}$, inciso II, da Constituição e reafirmar o mesmo princípio ao tratar dos temas mais sensíveis aos direitos dos cidadãos, impondo limites ao poder de punir, de tributar e de limitar o exercício da atividade econômica, condicionando-o a algum tipo de autorização. Assim, salvo nas situações expressamente previstas no texto original da Constituição e outras previstas por emenda constitucional, dentro dos limites do poder de reforma, a Administração não pode inovar no ordenamento jurídico.

\footnotetext{
${ }^{321}$ MARQUES NETO, Floriano Azevedo. Agências reguladoras independentes, fundamentos e seu regime jurídico. $2^{\mathrm{a}}$ reimpressão. Belo Horizonte: Fórum, 2009, p. 108.

322 BANDEIRA DE MELLO, Celso Antônio. Pareceres de direito administrativo. São Paulo: Malheiros, 2011, p. 342.
} 


\subsubsection{Relação de sujeição especial entre o Banco Central e os agentes do sistema financeiro - Celso Antônio Bandeira de Mello}

Em determinadas atividades econômicas, existe a necessidade de prévia autorização do Estado para o seu exercício, como as instituições financeiras, seguradoras, previdência e de capitalização. Como já vimos, essa autorização não se confunde com o regime jurídico de concessão de serviço público.

Nesses casos, há um grande interesse público em que não venham a ser provocados danos para a população em geral. São atividades privadas que, pelo seu elevado grau de importância econômica e social, passam a ter um tratamento específico. Diogo de Figueiredo Moreira Neto denomina de serviços privados de interesses públicos, "assim por lei considerados todos aqueles que, não obstante o prevalecente interesse privado, atendam também ao público; neste caso, porém, recorde-se, não existe qualquer delegação de serviço público".323

Celso Antônio Bandeira de Mello, com base em Renato Alessi, destaca que a legislação pode estabelecer um regime jurídico de relação especial com o Estado, em que há submissão a "uma liberdade administrativa muito mais ampla, (...) em que vige a supremacia especial da Administração". ${ }^{324}$ Esta relação seria o fundamento do poder regulatório entre as instituições financeiras e o Conselho Monetário Nacional e o Banco Central, como segue:

Deveras, há que distinguir duas situações. Uma, a que resulta das leis para a coletividade em geral e que, por pressupor uma atuação administrativa, demanda a edição de regulamentos, atos editáveis para reger seus comportamentos no confronto com os administrados. Outra, a que, de fora parte a questão do primado legal, a ser, obviamente, sempre respeitado, corresponde aos sujeitos que, por haverem travado com o Poder Público um vínculo específico, vêem-se colhidos por mandamentos, por injunções peculiares, em suma, por uma disciplina de comportamentos só pertinente

\footnotetext{
${ }^{323}$ MOREIRA NETO, Diogo de Figueiredo. Mutações do direito administrativo. Rio de Janeiro: Renovar, 2000, p. 137-138.

324 BANDEIRA DE MELLO, Celso Antônio. Grandes temas de direito administrativo. São Paulo: Malheiros, 2009, p. 263.
} 
aos dessarte vinculados e que lhes é imponível pela própria Administração, já que esta estará supedaneada nas prerrogativas que lhe resultam deste mesmo vínculo.

Os poderes que, neste caso, assistem aos sujeitos administrativos são exercitáveis em vista da adequada condução dos interesses jurídico-públicos suscitados na intimidade da relação especial de que se trate e decorrem da índole desta última, correspondendo, então, à contrapartida da situação específica em que o administrado se viu investido. É o que se passa com as disposições e determinações emanadas de pessoas ou órgãos administrativos, tais como, e.g., o Conselho Monetário Nacional ou o próprio Banco Central em relação às entidades privadas integrantes do Sistema Financeiro (Lei 4.595, de 31.12.1964) ou, também, a Comissão de Valores Mobiliários no que atina às entidades privadas que operam no sistema de distribuição de títulos ou valores mobiliários (Lei 4.728, de 14.7.1965). ${ }^{325}$

Nas relações de sujeição especial, segundo Celso Antônio Bandeira de Mello, o poder regulamentar decorre do "próprio vínculo específico instaurado pelo ato de habilitação do administrado" ${ }^{326}$, que, no caso das instituições financeiras, seria a autorização prevista no art. 18 da Lei 4595/64. ${ }^{327}$

O autor, entretanto, em publicação mais recente, destaca os riscos ao sistema de direitos fundamentais declarados na Constituição, pois "de nada adiantariam os arts. $5^{\circ}$, II, 37 e 84, IV, se, ulteriormente, o legislador pudesse entregar, de mão beijada, a esfera de liberdade e da propriedade dos administrados para ser disciplinada por via de regulamento". ${ }^{328}$ Ele também reafirma entendimento manifestado anteriormente em relação à vedação de inovação no ordenamento jurídico por ato infralegal, "sempre que seja impossível afirmar-se que aquele específico direito, dever,

325 BANDEIRA DE MELLO, Celso Antônio. Grandes temas de direito administrativo. São Paulo: Malheiros, 2009, p. 263-264.

326 BANDEIRA DE MELLO, Celso Antônio. Grandes temas de direito administrativo. São Paulo: Malheiros, 2009, p. 264.

${ }^{327}$ Lei 4595/64: Art. 18. As instituições financeiras somente poderão funcionar no País mediante prévia autorização do Banco Central da República do Brasil ou decreto do Poder Executivo, quando forem estrangeiras.

${ }^{328}$ BANDEIRA DE MELLO, Celso Antônio. Pareceres de direito administrativo. São Paulo: Malheiros, 2011, p. 345. 
obrigação, limitação ou restrição já estavam estatuídos e identificados na lei regulamentada". 329

Assim, o autor critica a delegação legislativa a órgãos da administração da competência para expedirem resoluções sobre matéria tipicamente de lei:

Nesta trilha viciosa, inúmeras têm sido as leis que defendem, sic et simpliciter, a órgãos colegiais do Executivo ou a entidades da Administração indireta poder de expedir decisões ('resoluções') cujo conteúdo só pode ser o de lei. Tais delegações serão sempre nulas, pelo quê ao Judiciário assiste como guardião do Direito - fulminar a norma que delegou e a norma produzida por delegação. ${ }^{330}$

A autorização para o exercício da atividade econômica seria, então, apenas um modo de controle prévio do atendimento das condições previstas em lei, sem mencionar uma capacidade para o estabelecimento de um regime de sujeição especial, como segue:

Eis por que não cabe um 'registro especial' de certo ou certos setores econômicos para fins de impor aos que lhe desejam assujeitados um regime peculiar, mais exigente que o vigorante para todos os demais, já que não existe a liberdade administrativa de delinear a amplitude da livre iniciativa ou de restringir-lhe as possibilidades de expressão. Há unicamente, como é natural, um controle, que em certos casos, no das autorizações, é prévio, sobre a adoção, pelo empreendedor, de todas as providências técnicas requeridas para que sua atuação não agrida interesses relevantes para o convívio social. ${ }^{331}$

\footnotetext{
${ }^{329}$ BANDEIRA DE MELLO, Celso Antônio. Ato administrativo e direito dos administrados. São Paulo: RT, 1981, p. 98.

330 BANDEIRA DE MELLO, Celso Antônio. Pareceres de direito administrativo. São Paulo: Malheiros, 2011, p. 349.

${ }^{331}$ BANDEIRA DE MELLO, Celso Antônio. Pareceres de direito administrativo. São Paulo: Malheiros, 2011, p. 353.
} 
Em nossa opinião, a melhor interpretação do princípio da legalidade é a de que o artigo 18 da Lei 4595/64 prevê a fiscalização prévia pelo Banco Central do atendimento aos requisitos legais, referentes a integralização do capital, registro de atos constitutivos, entre outros, para o início das atividades de instituição financeira. A relação de sujeição especial, por outro lado, é encontrada no estabelecimento de um vínculo decorrente da adesão a um regime jurídico próprio, como o ingresso em universidade pública, a celebração de contrato com o poder público, ingresso em estabelecimento correcional, por exemplo.

\subsection{Previsão de infrações e sanções em ato infralegal}

Como apresentado, a edição de normas pelo Conselho Monetário Nacional e pelo Banco Central do Brasil é compatível com o sistema de distribuição da competência legislativa adotado pela Constituição Federal de 1988, desde que se limite ao detalhamento técnico da legislação, sem inovar no ordenamento jurídico.

O CMN e o Banco Central, embora não se enquadrem propriamente no modelo de agências reguladoras norte-americano, foram instituídos com base neste modelo, mas sem a previsão de procedimento para elaboração e aprovação de normas que assegurasse transparência e representatividade dos cidadãos.

A Lei 4.595/64 transferiu o poder de legislar em matéria de sistema financeiro, de modo a caracterizar delegação legislativa. A recepção desta delegação pela Constituição Federal de 1988 somente seria possível por lei, e não medida provisória, editada dentro do prazo previsto pelo art. 25 do Ato das Disposições Constitucionais Transitórias, o que não ocorreu.

Assim, as normas oriundas do CMN e do Banco Central do Brasil limitam-se a "aspectos puramente técnicos, não definidos pelo legislador e que não alterem o alcance da lei, ou têm que ter efeito exclusivamente interno, limitado ao 
próprio âmbito do órgão, sob pena de inconstitucionalidade, por infringência ao princípio da legalidade e invasão em área reservada ao legislador". 332

Desse modo, o Banco Central do Brasil somente pode impor sanções fora do âmbito da própria autarquia quando houver lei com previsão de todos os elementos que tornem inequívocos o delineamento da infração e a respectiva sanção, dentro de uma margem de razoabilidade.

${ }^{332}$ DI PIETRO, Maria Sylvia Zanella. Parcerias na administração pública. $7^{\mathrm{a}}$ ed. São Paulo: Atlas, 2009, p. 194. 


\section{SANÇÕES APLICÁVEIS PELO BANCO CENTRAL DO BRASIL}

\subsection{Introdução}

Demonstramos nos capítulos anteriores a inexistência de hierarquia entre os elementos integrantes da interpretação, razão pela qual a interpretação não se resume ao sentido do texto legal. Ela deve levar em conta o contexto normativo, os aspectos históricos, os princípios do ordenamento e as condições fáticas.

Como leciona Arthur Meier-Hayoz, sentido literal tem "uma dupla função: ele é o ponto de partida para a investigação jurisprudencial do sentido e demarca, ao mesmo tempo, as fronteiras da atividade interpretativa" ${ }^{333}$. O intérprete "deve partir do sentido literal e, por meio do sentido literal, é delimitado o campo em que a interpretação poderá se dar" ${ }^{334}$. Afora, haverá inovação para além da lei.

A separação entre interpretação e desenvolvimento do direito implica em que a atividade de regulamentação deve limitar-se à atividade de interpretação e de detalhamento da norma, sendo vedada à Administração a função legislativa suplementar.

A partir da concepção do direito como sistema constituído exclusivamente por normas válidas orientado a partir de princípios ético-jurídicos, o princípio da legalidade destaca-se tendo como núcleo os valores fundamentais como liberdade e democracia.

Entretanto, não é possível à lei exaurir o detalhamento de cada hipótese de infração administrativa, de modo que ela utiliza tipos nos quais devem estar reunidos os

\footnotetext{
${ }^{333}$ No original: "Der Wortlaut hat danach eine doppelte Aufgabe: Er ist Ausgangspunkt für die richterliche Sinnermittlung und steckt zugleich die Grenzen seiner Auslegungstätigkeit ab" (tradução livre). MEIERHAYOZ, Arthur. Der Richter als Gesetzgeber: eine Besinnung auf die von den Gerichten befolgten Verfahrensgrundsätze im Beriche, der freien richterlichen Rechtsfindung gemäss Art. 1 Abs. 2 des schweizerischen Zivilgesetzbuches. Zürich : Juris-Verlag, 1951. p. 42.

${ }^{334}$ No original: "Vom Wortlaut hat der Richter auszugehen und durch den Wortlaut wird ihm der Raum abgegrenzt, innerhalb dessen seine Auslegung sich bewegen muss" (tradução livre). MEIER-HAYOZ, Arthur. Der Richter als Gesetzgeber: eine Besinnung auf die von den Gerichten befolgten Verfahrensgrundsätze im Beriche, der freien richterlichen Rechtsfindung gemäss Art. 1 Abs. 2 des schweizerischen Zivilgesetzbuches. Zürich : Juris-Verlag, 1951. p. 42.
} 
elementos que possibilitem a identificação da conduta. Quanto às hipóteses de sanção aplicáveis em cada caso, estas não podem ser demasiadamente amplas, mas apenas deixar certa margem para permitir que haja proporcionalidade entre a gravidade da conduta e a punição.

No presente capítulo, serão analisadas as regras sancionadoras aplicadas pelo Banco Central do Brasil, não como um catálogo de tipos sancionatórios, mas a partir das suas estruturas.

\subsection{Classificação das sanções administrativas}

O Conselho Monetário Nacional e o Banco Central do Brasil, mesmo sob a Constituição Federal de 1988, vêm editando normas sobre infrações por meio de atos infralegais. O que não significa que são todas ilegais ou inconstitucionais.

A fim de identificar a compatibilidade com o princípio da legalidade, classificaremos estas normas em quatro grupos: (i) a lei prevê infração e sanção; (ii) a lei especifica infração mas a sanção é vaga; (iii) a lei prevê de modo vago a infração e sanção e (iv) lei não delimita infração e sanção.

\subsubsection{Grupo 1: a lei apresenta infração e sanção}

Neste grupo estão incluídas as regras cujos elementos essenciais estão sediados em textos legais, ou seja, em diplomas com status de lei, como lei complementar, lei ordinária, lei delegada e medida provisória.

Ainda que sua aplicação dependa de detalhamento em sede de normativo infralegal, é possível identificar quando ocorre a infração e a respectiva sanção aplicável apenas com o texto de diplomas com status de lei. O regulamento apenas consistirá em um exercício de fixação de regras de procedimento e de regramento técnico, dentro dos limites da interpretação, ou seja, dentro dos limites fixados pelos possíveis significados dos termos empregados no texto legal. 
Assim, como exemplo, é possível apresentar a regra sancionadora que impõe advertência para irregularidades na escrituração contábil, como pode ser constatado no $\S 1^{\circ}$ do art. 44 da Lei 4595/64, como segue:

$\S 1^{\circ}$ A pena de advertência será aplicada pela inobservância das disposições constantes da legislação em vigor, ressalvadas as sanções nela previstas, sendo cabível também nos casos de fornecimento de informações inexatas, de escrituração mantida em atraso ou processada em desacordo com as normas expedidas de conformidade com o art. $4^{\circ}$, inciso XII, desta lei. ${ }^{335}$

É possível extrair do dispositivo que constitui infração administrativa fornecer informações incorretas à fiscalização, deixar de manter atualizada a escrituração contábil e registrar a movimentação financeira em desacordo com a técnica contábil, de acordo com os padrões instituídos pelo Conselho Monetário Nacional.

Não cabe à lei entrar nos detalhes sobre a forma de escrituração contábil das instituições financeiras. O dever de registrar as atividades por meio de balanços semestrais já está previsto no art. 31 da Lei 4595/64. ${ }^{336}$ A forma de execução, ou seja, os detalhamentos técnicos, a enumeração dos títulos contábeis, em que situações devem ser realizadas as provisões, entre outras questões, constitui matéria própria de regulamento, desde que não implique, de modo oblíquo, em instituição de novas obrigações. Assim, a padronização do nome das contas de receitas pela COSIF (Plano Contábil das Instituições do Sistema Financeiro Nacional) é um típico detalhamento técnico que permite padronização e transparência na análise do resultado de um banco comercial.

A respectiva sanção também é definida em lei: advertência. Neste caso não há margem de dúvida para sua aplicação. As questões procedimentais como o órgão competente, a forma utilizada (eletrônica ou em papel), entre outras, podem ser consideradas como detalhamento da norma, matéria típica de regulamento.

\footnotetext{
335 Art. $4^{\circ}$ Compete ao Conselho Monetário Nacional, segundo diretrizes estabelecidas pelo Presidente da República: (...) XII - Expedir normas gerais de contabilidade e estatística a serem observadas pelas instituições financeiras; (...).

336 Art. 31. As instituições financeiras levantarão balanços gerais a 30 de junho e 31 de dezembro de cada ano, obrigatoriamente, com observância das regras contábeis estabelecidas pelo Conselho Monetário Nacional.
} 
Assim, as sanções classificadas neste grupo atendem a regra decorrente do princípio da legalidade que proíbe a imposição de sanções administrativas sem previsão legal, pois os elementos estão em diplomas com status de lei e os regulamentos, mesmo que necessários para verificação da ocorrência do ilícito administrativo, apenas cumprem a função de fiel execução da lei.

\subsubsection{Grupo 2: a lei prevê infração mas a sanção é vaga}

Neste grupo estão as normas sancionadoras em que os elementos dos tipos de infração e de sanção estão contidos em textos legais, mas que, de alguma forma, o legislador deixa de indicar a sanção cabível, enumera diversas possibilidades de sanções aplicáveis ou estabelece quantidade indefinida ou excessivamente ampla de sanção a ser imposta.

É possível destacar como exemplo a norma do artigo $44, \S 7^{\circ}$, da Lei 4595/64, a seguir transcrito.

$\S 7^{\circ}$ Quaisquer pessoas físicas ou jurídicas que atuem como instituição financeira, sem estar devidamente autorizadas pelo Banco Central da República do Brasil, ficam sujeitas à multa referida neste artigo e detenção de 1 a 2 anos, ficando a esta sujeitos, quando pessoa jurídica, seus diretores e administradores.

A hipótese de infração também não deixa maiores margens para identificação do tipo. Atuar como instituição financeira consiste em praticar atividade econômica de intermediação de valores, conceder empréstimos em caráter não eventual, captar recursos, administração e custódia de títulos, tudo dentro dos moldes previstos no art. 17 da Lei 4595/64:

Art. 17. Consideram-se instituições financeiras, para os efeitos da legislação em vigor, as pessoas jurídicas públicas ou privadas, que tenham como atividade principal ou acessória a coleta, intermediação ou aplicação de recursos financeiros próprios ou de terceiros, em moeda nacional ou estrangeira, e a custódia de valor de propriedade de terceiros. 
Parágrafo único. Para os efeitos desta lei e da legislação em vigor, equiparam-se às instituições financeiras as pessoas físicas que exerçam qualquer das atividades referidas neste artigo, de forma permanente ou eventual.

A multa a ser aplicada não constitui um valor fixo em moeda. A lei apenas faz referência ao termo "multa pecuniária variável". Diante do princípio da legalidade, seria possível com tal dispositivo permitir que a Administração pudesse livremente escolher o valor da multa? $\mathrm{Ou}$ as circunstâncias de fato determinam a interpretação a ser dada ao texto, impondo ao aplicador que, de alguma forma, o valor da sanção esteja diretamente relacionado ao total do volume de valores envolvido na prática ilícita ou dos frutos decorrentes? Ou a situação consiste em verdadeira delegação oblíqua da função legislativa, que somente poderia ser procedida na forma prevista na Constituição Federal?

Para Celso Antônio Bandeira de Mello, a lei é inválida pois o legislador deve fixar parâmetros, com indicação de limites, para a aplicação da sanção pela Administração, como segue:

Assim também não se poderá considerar válida lei administrativa que preveja multa variável de um valor muito modesto para um extremamente alto, dependendo da gravidade da infração, porque isto significaria, na real verdade, a outorga de uma 'discricionariedade' tão desatada, que a sanção seria determinável pelo administrador e não pela lei, incorrendo esta em manifesto vício de falta de 'razoabilidade'. É dizer: teria havido um simulacro de obediência ao princípio da legalidade; não, porém, uma verdadeira obediência a ele. Norma que padecesse deste vício seria nula, por insuficiência de delimitação da sanção. ${ }^{337}$

Mesmo entendimento é compartilhado por Heraldo Garcia Vitta, que também aponta ser necessária a fixação em lei dos limites quantitativos para a Administração exercer o poder de punir, como segue:

${ }^{337}$ BANDEIRA DE MELLO, Celso Antônio. Curso de direito administrativo. $28^{\mathrm{a}}$ ed. São Paulo: Malheiros, 2011, p. 862. 
Se o legislador estabelece liberdade amplíssima à autoridade para impor a penalidade administrativa, nos limites de mínimo e máximo estipulados, o particular não tem como saber, antecipadamente, qual seria a provável e específica consequiência de sua conduta, pressuposto da pena. Isso equivaleria à inexistência de lei formal a regular a quantidade de pena a ser imposta ao infrator. $^{338}$

Como já apresentado no Capítulo 3, a vagueza do legislador nestes casos implica em uma forma oblíqua de delegação legislativa, pelo que não é admitida no ordenamento jurídico, ao menos no exercício do poder de punir pelo Estado.

\subsubsection{Grupo 3: a lei prevê hipóteses vagas de infração e de sanção administrativa}

Há situações em que a administração se utiliza de termos vagos sem delimitar características que sirvam de modo suficiente para constituir um tipo de infração.

A situação não se confunde com a utilização pela lei de termos normativos que exigem a avaliação subjetiva do fato ${ }^{339}$ (tal como conduta imoral, cobrança vexatória, entre outros). Como já vimos, Karl Engisch denomina de "conceitos carecidos de um preenchimento valorativo", pois são preenchidos caso a caso, por meio de atos de valoração objetiva a partir das “valorações preexistentes num setor social 'dirigente', 'relevante", 340 . A valoração dos fatos, como já visto, consiste em um processo de interpretação.

Também não estão compreendidas nesta classificação as situações em que a lei emprega termos ou critérios técnicos, os quais deverão ser detalhados por definições técnicas regulamentares, próprias das áreas de contabilidade, engenharia ou outros ramos do conhecimento.

\footnotetext{
${ }^{338}$ VITTA, Heraldo Garcia. A sanção no direito administrativo. São Paulo: Malheiros, 2003, p. 91.

339 ENGISCH, Karl. Introdução ao pensamento jurídico. $9^{\mathrm{a}}$ ed. Lisboa: Fundação Calouste Gulbenkian, 2004, p. 213.

340 ENGISCH, Karl. Introdução ao pensamento jurídico. $9^{\mathrm{a}}$ ed. Lisboa: Fundação Calouste Gulbenkian, 2004, p. 237.
} 
O critério de classificação aqui empregado é a ausência de fixação de parâmetros, o que permite uma vasta gama de fatos que impossibilita a identificação dos elementos do tipo e, portanto, dos limites do que seja lícito.

Como exemplo, a própria Lei $4595 / 64$ no art. $44, \S 4^{\circ}$, menciona como tipo a prática de infrações graves, como segue:

As penas referidas nos incisos III [suspensão do exercício de cargos] e IV [inabilitação temporária ou permanente para exercícios de cargos], deste artigo, serão aplicadas quando forem verificadas infrações graves na condução dos interesses da instituição financeira....

Definir um tipo de infração pela expressão praticar "infrações graves" consiste em uma verdadeira tautologia, o que impossibilita por completo identificar os elementos. Como define Nicola Abbagnano, o enunciado com esta característica é "vicioso porquanto inútil, visto repetir na conseqüência, no predicado ou no definiens o conceito já contido no primeiro membro: M. de la Palisse, quinze minutos antes de morrer, ainda estava vivo". 341

Assim, não há como admitir a compatibilidade das hipóteses de infração deste grupo com o sistema constitucional vigente a partir da Constituição de 1988.

\subsubsection{Grupo 4: infrações e sanções previstas em ato administrativo}

Neste grupo estão compreendidas as infrações e sanções definidas em ato infralegal, seja decreto presidencial, resolução do Conselho Monetário Nacional, circulares e outros atos emanados do Banco Central.

Como exemplo, cabe trazer a Resolução 2.878, de 27/09/2001, do CMN que ficou conhecida por Código de Defesa do Consumidor Bancário ${ }^{342}$. O ato infralegal instituiu diversas normas a serem observadas pelas instituições financeiras em relação às

${ }^{341}$ ABBAGNANO, Nicola. Dicionário de filosofia. São Paulo: Martins Fontes, 2003, p. 939.

${ }^{342}$ A Resolução 2.878 do CMN foi revogada pela Resolução 3.694 de 26.03.2009. 
operações contratadas em geral e atribuiu ao Banco Central a função de baixar outras normas, como segue:

Art. 19. O descumprimento do disposto nesta Resolução sujeita a instituição e os seus administradores às sanções previstas na legislação e regulamentação em vigor.

Art. 20. Fica o Banco Central do Brasil autorizado a:

I - baixar as normas e a adotar as medidas julgadas necessárias à execução do disposto nesta Resolução, podendo inclusive regulamentar novas situações decorrentes do relacionamento entre as pessoas físicas e jurídicas especificadas nos artigos anteriores;

II - fixar, em razão de questões operacionais, prazos diferenciados para o atendimento do disposto nesta Resolução.

O art. 19 supracitado não poderia ser mais vago ao definir quais seriam as consequências pelo descumprimento dos deveres enunciados na Resolução. Quais seriam sanções previstas na legislação e na regulamentação em vigor? Seriam as sanções enumeradas no art. 56 do Código de Defesa do Consumidor? ${ }^{343}$ Ou aquelas da Lei 4595/64? E em que medida? A norma não esclarece.

Como já afirmamos, não é cabível a instituição de hipóteses de infrações e de sanções administrativas pela Administração Pública. Mesmo que se entendessem como aplicáveis as sanções gerais previstas no art. 44 da Lei 4.595/64, concordamos com Heraldo Garcia Vitta, quando afirma:

\footnotetext{
${ }^{343}$ Art. 56. As infrações das normas de defesa do consumidor ficam sujeitas, conforme o caso, às seguintes sanções administrativas, sem prejuízo das de natureza civil, penal e das definidas em normas específicas: I - multa; II - apreensão do produto; III - inutilização do produto;

IV - cassação do registro do produto junto ao órgão competente;

V - proibição de fabricação do produto;

VI - suspensão de fornecimento de produtos ou serviço;

VII - suspensão temporária de atividade;

VIII - revogação de concessão ou permissão de uso;

IX - cassação de licença do estabelecimento ou de atividade;

$\mathrm{X}$ - interdição, total ou parcial, de estabelecimento, de obra ou de atividade;

XI - intervenção administrativa;

XII - imposição de contrapropaganda”.
} 
Nem se alegue que seria possível a lei estabelecer sanções, deixando a atos subalternos determinar as condutas ilícitas; é que ocorreria ofensa ao princípio da legalidade - pois tanto as penalidades, quanto as infrações, devem estar plasmadas em lei formal, a fim de garantir a segurança jurídica dos administrados. $^{344}$

Sérgio Ferraz e Adilson de Abreu Dallari fundamentam a aplicação do princípio da reserva legal e do princípio da tipicidade igualmente, como segue:

Em primeiro lugar impõe-se bradar em altas vozes: não há sanção administrativa admissível sem prévia capitulação legal (lei em senso estrito). Nem é preciso, no particular, recorrer ao inciso XXXIX do art. $5^{\circ}$ da Constituição Federal, assim evitando a polêmica com aqueles que pretendem a aplicabilidade desse comando exclusivamente ao crime (também em senso estrito): bastará nos afinarmos ao inciso II do mesmo art. $5^{\circ}$, consagrador do princípio da legalidade, marco fundamental da atividade de qualquer natureza. Em definitivo: sanção administrativa só pode decorrer de lei anterior, e lei em cunho formal (não bastando simples medida provisória, que não passa de lei sob condição, lei a título precário - o que, a toda evidência, não se presta a definir infrações e respectivas sanções: a repercussão e a profundidade do enquadramento infracional e da decorrente submissão sancionatória são incompatíveis com um juízo de validade definitiva pendendo da hipotética conversão da medida em lei). ${ }^{345}$

Também como já afirmado, concordamos como Rafael Munhoz de Mello quando destaca que o legislador "tem a liberdade para tipificar uma conduta como crime ou infração administrativa”. Observe que essa escolha é uma questão de política legislativa. Portanto, "é necessário que as garantias que se aplicam num caso e noutro sejam comuns". Ressalta o autor que, do contrário, "a opção entre um tipo de ilícito e outro poderia ser feita tendo em vista o nível de garantias de que dispõe o particular: tipificar-se-

\footnotetext{
${ }^{344}$ VITTA, Heraldo Garcia. A sanção no direito administrativo. São Paulo: Malheiros, 2003, p. 85.

${ }^{345}$ FERRAZ, Sérgio; DALLARI, Adilson de Abreu. Processo administrativo. $2^{\mathrm{a}}$ ed. São Paulo: Malheiros, 2007, p. 154-155.
} 
ia conduta como ilícito administrativo para fugir das garantias outorgadas aos particulares no campo do direito penal". 346

\subsection{Entendimento do Poder Judiciário}

Entretanto, observamos que o Poder Judiciário tem adotado em geral uma postura de maior tolerância em relação à definição de infrações pela Administração. Neste sentido, pode-se mencionar trecho do voto da relatora, Min. Eliana Calmon, acórdão proferido pelo Superior Tribunal de Justiça no julgamento do Recurso Especial 324.181$\mathrm{RS}$, em que se encontra o entendimento de que a lei deve conter os elementos do tipo ou, com o que discordamos em parte, mencionar que parte deve estar em atos infralegais, como segue:

A questão passa, portanto, pela análise da validade da integração da norma legal por normas infralegais de cunho técnico para efeito de fundamentar a aplicação de penalidade administrativa.

Dentro do que foi prequestionado, temos de estabelecer algumas premissas para, só após, examinar a legislação.

O primeiro aspecto a encarar é que só a lei pode estabelecer sanção administrativa, estando condenadas todas as penalidades oriundas de atos normativos que não se constituam em lei em sentido formal.

O segundo aspecto a observar é a natureza da sanção que se situa no plano do Direito Administrativo, sem conotação alguma com a esfera penal.

Estabelecidos esses dois fundamentais pontos, passa-se a examinar o art. 44 da Lei 4.595, de 31/12/64, que dispõe sobre a política e as instituições monetárias, bancárias e creditícias.

O mencionado artigo dirige-se contra as instituições financeiras, seus diretores, membros de conselhos administrativos, gerentes, fiscais e assemelhados, o que afasta o argumento de que somente as instituições financeiras poderiam sofrer sanções pela Lei 4.595/64.

${ }^{346}$ MELLO, Rafael Munhoz de. Princípios constitucionais de direito administrativo sancionador: as sanções administrativas à luz da Constituição Federal de 1988. São Paulo: Malheiros, 2007, p. 106. 
Dentre as várias espécies de sanção, enumeradas nos diversos incisos, destaca, o $\S 2^{\circ}$ do artigo, a multa, para dizer que será aplicada até o máximo de 200 (duzentas) vezes o maior salário-mínimo nas hipóteses das alíneas 'a' e 'b'.

Segundo o BANCO CENTRAL DO BRASIL, deveu-se a aplicação da multa aos fatos seguintes:

a) autorização de adiantamento ao Tesouro de valores acima do limite estabelecido na Resolução 905/84, do CMN; e

b) desrespeito à Circular 237/74 do BACEN, ao impedir a transferência dos saldos das contas de crédito em liqüidação e dos saldos devedores da conta corrente do Tesouro do Estado.

Temos, então, o primeiro questionamento, porque a previsão da sanção de multa, contida no art. $44, \S 2^{\circ}$, letra 'b', diz respeito aos tipos ali descritos e não às infrações da Resolução 905/84 e da Circular 237/74, estes os diplomas legais que são mencionados como transgredidos.

A alínea 'b' considera infração:

a) infringir as disposições relativas ao capital, fundo de reserva, encaixe, recolhimentos compulsórios, taxa de fiscalização, serviços e operações;

b) não atendimento aos arts. 27 e 33; e

c) abuso de concorrência.

A redação dada à alínea induz à interpretação de que as diversas situações ensejadoras da sanção estariam em disposições da mesma lei.

Embora não se possa aqui falar de norma penal em branco, como disse o Tribunal, o certo é que a sanção deveria estar contida por inteiro na Lei 4.595/64, ou conter no bojo da lei a indicação de que a tipicidade englobaria diplomas infralegais. Mas, como visto, ao contrário, disse o legislador que os tipos estariam inseridos na própria lei.

Diante dos precisos termos da Lei 4.595/64, confirmo o acórdão, improvendo o recurso. 


\subsection{Conclusão}

A partir da classificação das normas de infração e sanção administrativas em quatro grupos, demonstramos ser possível o preenchimento de conceitos técnicos utilizados por lei para definir os elementos do tipo, desde que haja clareza e delimitação dos enunciados.

Por outro lado, a simples menção pelo art. 44, $\S 2^{\circ}$, b, da Lei 4595/64, de que o Banco Central irá impor sanções por descumprimento de regras "relativas ao capital, fundo de reserva, encaixe, recolhimentos compulsórios, taxa de fiscalização, serviços e operações", somente é admissível se as respectivas condutas reprováveis, ou tipos, estiverem declarados em lei e se houver algum critério de graduação, pois a simples autorização para multar de um centavo a duzentos salários-mínimos é demasiadamente vaga.

Concordamos com Silvio Luís Ferreira da Rocha quando afirma que a Administração Pública "só pode ser exercida na conformidade com a lei; é atividade sublegal, infralegal, consistente na expedição de comandos complementares à lei". ${ }^{347}$ Deste modo, sua atuação "somente poderá ser a de agregar à lei nível de concreção, sem instaurar originariamente qualquer cerceio a direito de terceiros". 348

Como apresentamos, as hipóteses de infração e de sanção dos grupos 2 a 4 decorrem de atividade de instauração inaugural de cerceio, que ultrapassa os limites da interpretação e que, por isso, não encontra fundamento no sistema de distribuição da competência normativa pela Constituição Federal de 1988.

${ }^{347}$ ROCHA, Sílvio Luís Ferreira da. Terceiro setor. $2^{\text {a }}$ ed. São Paulo: Malheiros, 2006, p. 29.

${ }^{348}$ ROCHA, Sílvio Luís Ferreira da. Terceiro setor. $2^{a}$ ed. São Paulo: Malheiros, 2006, p. 29. 


\section{CONCLUSÃO}

Como foi demonstrado, o princípio da legalidade não pode ser entendido como mera formalidade burocrática para a atuação do Estado. Muito pelo contrário, ele é a própria essência do Estado de Direito, por meio do qual é efetivada a soberania popular que é exercida no processo legislativo. Somente por esse procedimento é que se pode inovar no mundo jurídico, isto é, limitar direitos e impor deveres pelo Estado.

A Administração Pública deve agir de acordo com os interesses públicos definidos em lei e não conforme os estabelecidos isoladamente pelo Poder Executivo. Consequentemente, a atividade sancionatória do Estado, por implicar na restrição de direitos individuais, deve ser exercida somente com a fiel observância dos princípios da legalidade e da tipicidade, a fim de evitar a arbitrariedade do agente administrativo que aplica a norma.

Como analisado, infrações e sanções administrativas somente podem ser instituídas por lei, conforme o processo legislativo. Lei esta que deve conter todos os elementos identificadores da infração e das respectivas sanções, de modo que a lei não seja uma outorga à Administração de amplos poderes para uso arbitrário do agente público. Também, permite que os administrados possam saber com antecedência as condutas que são proibidas e a respectiva sanção a que estarão sujeitos. Assim, o atual sistema constitucional de distribuição de competência não admite a inovação em matéria de infração e sanção por ato infralegal.

Demonstramos que essa especial característica da sanção decorre do caráter punitivo e restritivo de direitos que visa a impor uma consequência indesejada ao infrator com o propósito de desestimular condutas especialmente eleitas por uma sociedade. Assim, a lei deve conter os elementos do tipo infracional, o que não significa esgotar a descrição da conduta mediante conceitos, enquanto as hipóteses de sanção aplicáveis devem ser delimitadas de modo a evitar uma vasta liberdade à Administração. 
A forma de atuação do Conselho Monetário Nacional e do Banco Central foi herdada de um regime autoritário, no qual a legalidade foi substituída por uma pretensa qualidade técnica dos atos normativos emanados dos órgãos do Poder Executivo. Este modelo, entretanto, não foi acolhido pela Constituição Federal de 1988, que restabeleceu o regime democrático. Assim, não é possível admitir a manutenção de competência legislativa do Conselho Monetário Nacional e do Banco Central quanto às infrações e sanções.

Restou aos órgãos públicos competência unicamente para detalhamento do conteúdo da lei, dentro dos limites da interpretação. Por isso, é vedado o desenvolvimento do direito para a criação de novas hipóteses de infração ou sanções.

A interpretação implica na conceituação dos termos utilizados nos tipos, seja pelo detalhamento de normas técnicas que não criem novas obrigações (normas contábeis do plano COSIF, por exemplo), seja pelo preenchimento de termos que comportam conteúdo valorativo.

Somente é possível admitir discricionariedade, enquanto análise de conveniência e oportunidade, quando o resultado do processo de interpretação permite igualmente duas ou mais opções válidas.

Por outro lado, constitui desenvolvimento do direito pela Administração, por meio de delegação legislativa, a utilização de termos vagos na tipificação da conduta infracional bem como a autorização legal ampla de sanções aplicáveis pelo agente público.

Não há um regime de sujeição especial na relação entre o poder público e as instituições financeiras, pois a atividade bancária não resulta de delegação. A autorização para funcionamento não pode ultrapassar o controle prévio das condições objetivas previstas em lei para o início da atividade de banco. 
Finalmente, com a evolução da atividade do Estado nos países ocidentais em relação à forma de intervenção na economia, a sanção administrativa tornou-se um regime jurídico que deve ter regramento próprio dentro do sistema jurídico, especialmente a legalidade e a tipicidade. O exercício desse poder sancionatório deve ainda observar o princípio da razoabilidade, além dos demais princípios próprios do direito administrativo (expressos ou implícitos) 


\section{BIBLIOGRAFIA}

ABBAGnANO, Nicola. Dicionário de filosofia. São Paulo: Martins Fontes, 2003.

ALESSI, Renato. Diritto amministrativo. Milano: Giuffrè, 1949.

__- Instituciones de derecho administrativo, t. 1. Barcelona: Bosch, Casa Editorial, 1974.

ALEXY, Robert. Teoria da argumentação jurídica, a teoria do discurso racional como teoria da justificação jurídica. $2^{\mathrm{a}}$ ed. São Paulo: Landy, 2005.

___ - Teoria dos direitos fundamentais. Tradução de Virgílio Afonso da Silva. São Paulo: Malheiros, 2008.

ARAGÃO, Alexandre Santos de. Agências reguladoras, e a evolução do direito administrativo econômico. $2^{\mathrm{a}}$ ed. Rio de Janeiro: Forense, 2009.

ARAÚJO, Edmir Netto de. O ilícito administrativo e seu processo. São Paulo: RT, 1994.

ARIÑO, Gaspar. Economia y Estado. Buenos Aires: Abeledo-Perrot, 1993.

ATALIBA, Geraldo. O decreto regulamentar no sistema brasileiro. Revista de Direito Administrativo, n. 97, Rio de Janeiro, FGV, s.d., p. 28.

ÁVILA, Fernando Bastos de. Pequena enciclopédia de doutrina social da Igreja. São Paulo: Loyola, 1991

BANDEIRA DE MELLO, Celso Antônio. Ato administrativo $e$ direito dos administrados. São Paulo: RT, 1981.

-. Curso de direito administrativo. $28^{\mathrm{a}}$ ed. São Paulo: Malheiros, 2011.

- Conteúdo jurídico do princípio da igualdade. $3^{\mathrm{a}}$ ed., $17^{\mathrm{a}}$ tiragem. São Paulo:

Malheiros, 2009.

____ Grandes temas de direito administrativo. São Paulo: Malheiros, 2009.

____ Pareceres de direito administrativo. São Paulo: Malheiros, 2011.

-__- Discricionariedade e controle jurisdicional. $2^{\mathrm{a}}$ ed., $9^{\mathrm{a}}$ tiragem. São Paulo: Malheiros, 2008. 
BARROSO, Luis Roberto. O direito constitucional e a efetividade de suas normas. $2^{\mathrm{a}}$ ed. Rio de Janeiro: Renovar, 1993.

BECCARIA, Cesare. Dei Delitti e delle Pene. Milano: Francesco Sanvito, 1858.

BENJÓ, Isaac. Fundamentos de economia da regulação. Rio de Janeiro: Thex, 1999.

BEZNOS, Clóvis. Atos e processos administrativos. Boletim de Direito Administrativo, São Paulo, n. 1, 2006, p. 17-21.

____ Poder de polícia. São Paulo: RT, 1979.

BOBBIO, Norberto. Principi generali di diritto. Novissimo digesto italiano. Torino: Editrice Torinese, 1957, volume 13, p. 887-896.

____. Teoria da norma jurídica. Bauru: Edipro, 2001.

BONAVIDES, Paulo. Curso de direito constitucional. $7^{\mathrm{a}}$ ed. São Paulo: Malheiros, 1997.

BREAY, Claire. Magna Carta, manuscripts and myths. 2a ed. London: Britsh Library, 2010.

CAMARGO, Antonio Luís Chaves. Imputação objetiva e direito penal brasileiro. São Paulo: Cultural Paulista, 2001.

CANARIS, Claus-Wilhelm. Pensamento sistemático e conceito de sistema na ciência do direito. $2^{\mathrm{a}}$ ed. Lisboa: Fundação Calouste Gulbenkian, 1996.

CANOTILHO, José Joaquim Gomes. Direito constitucional e a teoria da Constituição. $3^{a}$ ed. Coimbra: Almedina, 1999.

CARREIRA ALVIM, José Eduardo. Tutela antecipada na reforma processual. $2^{\mathrm{a}}$ ed. Curitiba: Juruá, 1999.

CARVALHO FILHO, José dos Santos. Curso de direito administrativo. $18^{\mathrm{a}}$ ed. Rio de Janeiro: Lumen Juris, 2007.

CARVALHO, Paulo de Barros. Direito Tributário: fundamentos da incidência tributária. $3^{a}$ ed. revista e atualizada. São Paulo: Saraiva, 2004.

CASTRO, Carlos Roberto Siqueira. O devido processo legal e os princípios da razoabilidade e da proporcionalidade. $4^{\mathrm{a}}$ ed. Rio de Janeiro: Forense, 2006.

O Congresso e as delegações legislativas. Rio de Janeiro: Forense, 1986. 
COÊLHO, Sacha Calmon Navarro. Teoria e prática das multas tributárias. $2^{\mathrm{a}}$ ed. Rio de Janeiro: Forense, 1998.

COMPARATO, Fabio Konder. Abertura de crédito, nulidade de cláusula contratual, comentário. Revista de Direito Mercantil Industrial e Econômico Financeiro, n. 3, ano X, Nova Série, Rio de Janeiro, 1971, p. 59-63.

CRETELLA JÚNIOR, José. Do ilícito administrativo. Revista Forense, n. 244, Rio de Janeiro, 1973, p. 17-24.

___—_. O Estado e a obrigação de indenizar. São Paulo: Saraiva, 1980.

_____ Filosofia do direito administrativo. Rio de Janeiro: Forense, 1999.

___- Do ilícito administrativo. Revista da Faculdade de Direito da Universidade de São Paulo, n. 68, $1^{\circ}$ Fasc., Separata, São Paulo, 1973, p. 135-159.

DALLARI, Dalmo de Abreu. Elementos de teoria geral do Estado. 26 ${ }^{\mathrm{a}}$ ed. São Paulo: Saraiva, 2007.

DANTAS, F. C. de San Tiago. Igualdade perante a lei e due process of law. Revista Forense, volume 117, Rio de Janeiro, abr. 1948, p. 30.

____. Problemas de direito positivo. Rio de Janeiro: Forense, 1953.

DERZI, Misabel Abreu Machado. Direito tributário, direito penal e tipo. $2^{\mathrm{a}}$ ed. São Paulo: RT, 2007.

DUGUIT, Léon. Traité de Droit Constitutionnnel. 2. ed. Paris: Fontemoing, 1923.

DINAMARCO, Cândido Rangel. Instituições de direito processual civil. Volume 1. São Paulo: Malheiros, 2001.

DI PIETRO, Maria Sylvia Zanella. Direito administrativo. $23^{\mathrm{a}}$ ed. São Paulo: Atlas, 2010.

___- Parcerias na administração pública. $7^{\mathrm{a}}$ ed. São Paulo: Atlas, 2009.

-__- Discricionariedade administrativa na Constituição de 1988. $2^{\mathrm{a}}$ ed., $4^{\mathrm{a}}$ reimpressão. São Paulo: Atlas, 2007.

___ (Org.). Direito regulatório: temas polêmicos. Belo Horizonte: Fórum, 2009. ; RIBEIRO, Carlos Vinícius Alves (Orgs.). Supremacia do interesse público, e outros temas relevantes do direito administrativo. São Paulo: Atlas, 2010. 
DWORKIN, Ronald. Levando os direitos a sério. São Paulo: Martins Fontes, 2002.

ENGISCH, Karl. Introdução ao pensamento jurídico. $9^{\mathrm{a}}$ ed. Lisboa: Fundação Calouste Gulbenkian, 2004.

FALCÃO, Amilcar de Araújo. Funcionário público, natureza da pena disciplinar, disponibilidade, revisão de processo administrativo. Revista de Direito Administrativo, n. 48, Rio de Janeiro, FGV, abril-junho 1957, p. 531-541.

FERRAZ, Sérgio; DALLARI, Adilson de Abreu. Processo administrativo. $2^{\mathrm{a}}$ ed. São Paulo: Malheiros, 2007.

FERRAZ JÚNIOR, Tércio Sampaio. Introdução ao estudo do direito. $4^{\mathrm{a}}$ ed. São Paulo: Atlas, 2003.

___- Agências reguladoras: legalidade e discricionariedade. Texto disponível em: $<$ http://www.bresserpereira.org.br/documents/mare/Agencias/AgenciasRegulador as.PDF>. Acesso em 27 de novembro de 2011.

FERREIRA, Daniel. Sanções administrativas. São Paulo: Malheiros, 2001.

____ Teoria geral da infração administrativa a partir da Constituição Federal de 1988. Belo Horizonte: Fórum, 2009.

FERREIRA FILHO, Manoel Gonçalves. Princípios fundamentais de direito constitucional. $2^{\text {a }}$ ed. São Paulo: Saraiva, 2010.

____- O poder constituinte. $5^{\text {a }}$ ed. São Paulo: Saraiva, 2007.

_-_ Curso de direito constitucional. $36^{\mathrm{a}}$ ed. São Paulo: Saraiva, 2010.

FERREIRO LAPATZA, José Juan. Direito tributário: teoria geral do tributo. Barueri: Manole, 2007.

FIGUEIREDO, Lúcia Valle. Curso de direito administrativo. $8^{\mathrm{a}}$ ed. São Paulo: Malheiros, 2006.

FRAGOSO, Heleno. Lições de Direito Penal. 16 ${ }^{\mathrm{a}}$ ed. Rio de Janeiro: Forense, 2003.

GADAMER, Hans-Georg. Verdade e método, traços fundamentais de uma hermenêutica filosófica. 2a ed. Petrópolis: Vozes, 1998.

GARCIA DE ENTERRÍA, Eduardo. Hacia una nueva justicia administrativa. $2^{\mathrm{a}}$ ed. ampliada. Madrid: Civitas, 1992. 
GRAU, Eros Roberto. $O$ direito posto e o direito pressuposto. $8^{\mathrm{a}}$ ed. São Paulo: Malheiros, 2011.

GRINOVER, Ada Pellegrini et al. Código Brasileiro de Defesa do Consumidor comentado pelos autores do anteprojeto. $9^{\mathrm{a}}$ ed. Rio de Janeiro: Forense, 2007.

GROTTI, Dinorá Adelaide Musetti. Agências Reguladoras, uma visão critica e atual. Boletim de Direito Administrativo, volume 21, n. 8, agosto 2005, São Paulo, NDJ, p. 883-890.

-__- O serviço público e a constituição brasileira de 1988. São Paulo: Malheiros, 2003.

GUERRA, Sérgio. Controle judicial dos atos regulatórios. Rio de Janeiro: Lumen Juris, 2005.

HÄBERLE, Peter. Hermenêutica constitucional, a sociedade aberta dos intérpretes da constituição: contribuição para a interpretação pluralista e "procedimental" da Constituição. Tradução de Gilmar Ferreira Mendes. Porto Alegre: Sergio Antonio Fabris, 1997.

HABERMAS, Jürgen. Direito e democracia: entre facticidade e validade. Rio de Janeiro: Tempo Brasileiro, 1997.

HART, Herbert Lionel Adolphus. O conceito de direito. São Paulo: Martins Fontes, 2009.

HAURIOU, Maurice. Precis de droit administratif et de droit public: a l'usage des étudiants en licence et en doctorat ès-sciences politiques. $11^{\mathrm{a}}$ ed. Paris: Societé Recueil Général des Lois \& des Arrêts, 1927.

HUERGO LORA, Alejandro. Las sanciones administrativas. Madrid: Iustel, 2007.

JUSTEN FILHO, Marçal. Teoria geral das concessões de serviço público. São Paulo: Dialética, 2003.

___- Curso de direito administrativo. $5^{\text {a }}$ ed. São Paulo: Saraiva, 2010. O direito das agências reguladoras independentes. São Paulo: Dialética, 2002.

KELSEN, Hans. Teoria pura do direito. $7^{\mathrm{a}}$ ed. São Paulo: Martins Fontes, 2006. Jurisdição constitucional. $2^{\mathrm{a}}$ ed. São Paulo: Martins Fontes, 2007. 
LABAND, Paul. Droit public de l'Empire Allemand. Paris: V.Giard \& Brière, 1901. t. 2.

LARENZ, Karl. Derecho justo: fundamentos de ética jurídica. Madrid: Civitas, 1985.

-__- Metodologia da ciência do direito. $3^{\mathrm{a}}$ ed. Lisboa: Fundação Calouste Gulbenkian, 1997.

LEAL, Vítor Nunes. Delegações Legislativas. Revista de Direito Administrativo, volume V, Rio de Janeiro, FGV, julho de 1946, p. 378 a 391.

MAITLAND, Frederic Willian; FISHER, Herbert Albert Laurens. The constitutional history of England: a course of lectures. Nova Jersey: Lawbook Exchange, 2001.

MARQUES NETO, Floriano Azevedo. Aspectos jurídicos do exercício do poder de sanção por órgão regulador do setor de energia elétrica. Boletim de direito administrativo, n. 12, São Paulo, 2002, p. 945-960.

-__- Agências reguladoras independentes, fundamentos e seu regime jurídico. $2^{\mathrm{a}}$ reimpressão. Belo Horizonte: Fórum, 2009.

____ Regulação estatal e interesse público. São Paulo: Malheiros, 2002.

MAURER, Hartmut. Direito administrativo geral. Barueri: Manole, 2006.

MAYER, Otto. Le droit administratif allemand. Paris: V. Giard \& E.Brière, 1903, t. 1.

MAXIMILIANO, Carlos. Hermenêutica e aplicação do direito. $20^{\mathrm{a}}$ ed. Rio de Janeiro: Forense, 2011.

MEDINA OSÓRIO, Fábio. Direito administrativo sancionador. $3^{\mathrm{a}}$ ed. São Paulo: RT, 2009.

- (Coord.). Direito sancionador: sistema financeiro nacional. Belo Horizonte: Fórum, 2007.

MEIER-HAYOZ, Arthur. Der Richter als Gesetzgeber, eine Besinnung auf die von den Gerichten befolgten Verfahrensgrundsätze im Beriche, der freien richterlichen Rechtsfindung gemäss Art. 1 Abs. 2 des schweizerischen Zivilgesetzbuches. Zurique: Juris-Verlag, 1951.

MEIRELLES, Hely Lopes. Direito administrativo brasileiro. $20^{\mathrm{a}}$ ed. atualizada por Eurico de Andrade Azevedo et al. São Paulo: Malheiros, 1995. 
MELlO, Rafael Munhoz de. Princípios constitucionais de direito administrativo sancionador: as sanções administrativas à luz da Constituição Federal de 1988. São Paulo: Malheiros, 2007.

-_-_. Sanção administrativa e o princípio da legalidade. Revista Trimestral de Direito Público, n. 30, São Paulo, 2000, p. 139-165.

MERKL, Adolf. Teoría general del derecho administrativo. Granada: Comares, 2004.

MIRABETE, Julio Fabbrini. Manual de direito penal. São Paulo: Atlas, 1985.

MONTESQUIEU, Charles de Secondat. O espírito das leis. São Paulo: Martins Fontes, 2000.

MOREIRA, Egon Bockmann. Agências administrativas, poder regulamentar e o sistema financeiro nacional. Revista Eletrônica de Direito Administrativo Econômico (REDAE), Salvador, Instituto Brasileiro de Direito Público, n. 11, agosto/setembro/outubro, 2007. Disponível em: <http://www.direitodoestado.com.br/redae.asp>. Acesso em 17 de dezembro de 2011.

MOREIRA NETO, Diogo de Figueiredo. Curso de direito administrativo. $15^{\mathrm{a}}$ ed. Rio de Janeiro: Forense, 2009.

____. Mutações do direito administrativo. Rio de Janeiro: Renovar, 2000.

MORENO, Fernando Sainz. Conceptos jurídicos, interpretación y discrecionalidade administrativa. Madri: Civitas, 1976.

MÜLLER, Friedrich. O novo paradigma do direito, introdução à teoria e metódica estruturantes. $2^{a}$ ed. São Paulo: RT, 2009.

_-_ Metodologia do direito constitucional. $4^{\mathrm{a}}$ ed. São Paulo: RT, 2010.

NIETO, Alejandro. Derecho administrativo sancionador. $4^{\mathrm{a}}$ ed. ampliada, $2^{\mathrm{a}}$ reimpressão. Madrid: Tecnos, 2008.

NOVELLI, Flávio Bauer. Segurança dos Direitos Individuais e Tributação. Revista de Direito Tributário, n. 25/26, São Paulo, 1983, p. 159-175.

OLIVEIRA, José Roberto Pimenta. Os princípios da razoabilidade $e$ da proporcionalidade no direito administrativo brasileiro. São Paulo: Malheiros, 2006. 
OLIVEIRA, Regis Fernandes de. Infrações e sanções administrativas. $2^{\mathrm{a}}$ ed. revista, atualizada e ampliada São Paulo: RT, 2005.

PAPA JOÃO PAULO II. Carta Encíclica Centesimus Annus. São Paulo: Loyola, 1991.

PAPA PIO XI. Carta Encíclica Quadragesimo Anno. Disponível em: <http://www.vatican.va/holy_father/pius_xi/encyclicals/documents/hf_pxi_enc_19310515_quadragesimo-anno_po.html>. Acesso em 21 de agosto de 2008.

PIMENTEL, Manoel Pedro. O crime e a pena na atualidade. São Paulo: RT, 1983.

PIRES, Luis Manuel Fonseca. Limitações administrativas à liberdade e à propriedade. São Paulo: Quartier Latin, 2006.

____ Regime jurídico das licenças. São Paulo: Quartier Latin, 2006.

-__- Controle judicial da discricionariedade administrativa, dos conceitos jurídicos indeterminados às políticas públicas. Rio de Janeiro: Elsevier, 2009.

PORTA, Marcos. Processo administrativo e o devido processo legal. São Paulo: Quartier Latin, 2003.

PRATES, Marcelo Madureira. Sanção administrativa geral: anatomia e autonomia. Coimbra: Almedina, 2005.

QUEIRÓ, Afonso Rodrigues. O poder discricionário da administração. $2^{\mathrm{a}}$ ed. Coimbra: Coimbra, 1948.

RAWLS, John. Uma teoria da justiça. São Paulo: Martins Fontes, 1997.

RAZ, Joseph. Practical reason and norms. $3^{\mathrm{a}}$ ed. reimpressão. New York: Oxford University, 2002.

ROCHA, Sílvio Luís Ferreira da. Terceiro setor. $2^{\mathrm{a}}$ ed. São Paulo: Malheiros, 2006.

ROCHA, Jean Paul Cabral Veiga da. A capacidade normativa de conjuntura no direito econômico: o déficit democrático da regulação financeira. Tese (Doutorado), Universidade de São Paulo, São Paulo, 2004.

SARTORI, Giovanni. Engenharia constitucional: como mudam as constituições. Brasília: UnB, 1996.

SAVIGNY, Friedrich Carl von. de. System des heutigen römischen Rechts. Berlin: Veit und Camp, 1840. 
SCHMITT, Carl. Legalidade e legitimidade. Belo Horizonte: Del Rey, 2007.

SILVA, José Afonso da. Curso de direito constitucional positivo. $28^{\mathrm{a}}$ ed. São Paulo: Malheiros, 2007.

___- Direito urbanístico brasileiro. $5^{\text {a }}$ ed. São Paulo: Malheiros, 2008.

SILVA, Virgílio Afonso da. Princípios e regras: mitos e equívocos acerca de uma distinção. Revista Latino-Americana de Estudos Constitucionais 1. Belo Horizonte: Del Rey, 2003, p. 607-630.

SOUTO, Marcos Juruena Vellela. Desestatização, privatização, concessões, terceirizações e regulação. $4^{\mathrm{a}}$ ed. Rio de Janeiro: Lumen Juris, 2001.

SUNDFELD, Carlos Ari. Direito administrativo ordenador. $1^{\text {a }}$ ed., $3^{\text {a }}$ tiragem. São Paulo: Malheiros, 2003.

TÁCITO, Caio. Agências Reguladoras, Poder Normativo. Limites. Temas de Direito Público (Estudos e Pareceres) - $3^{\circ}$ volume. Rio de Janeiro: Renovar, 2002.

As Delegações Legislativas e o Poder Regulamentar. Revista de Direito Administrativo, n. 34, Rio de Janeiro, FGV, outubro a dezembro de 1953, p. 471 a 473.

TIPKE, Klaus; LANG, Joachim. Direito tributário. Volume 1. Porto Alegre: Sergio Antonio Fabris, 2008.

TOGNETTI, Eduardo. Atributos do ato administrativo. In: DI PIETRO, Maria Sylvia Zanella; RIBEIRO, Carlos Vinícius Alves (Orgs.). Supremacia do interesse público, e outros temas relevantes do direito administrativo. São Paulo: Atlas, 2010.

TORRES, Ricardo Lobo. Tratado de direito constitucional financeiro e tributário. Volume 2. Rio de Janeiro: Renovar, 2005.

_-__- Normas de interpretação e integração do Direito Tributário. $3^{\mathrm{a}} \mathrm{ed}$. Rio de Janeiro: Renovar, 2000.

____. O direito ao mínimo existencial. Rio de Janeiro: Renovar, 2009.

TORRES, Silvia Faber. O princípio da subsidiariedade no direito público contemporâneo. Rio de Janeiro: Renovar, 2001. 
TURCZYN, Sidnei. O Sistema Financeiro Nacional e a regulação bancária. São Paulo: RT, 2005.

UCKMAR, Victor. Principi Comuni di Diritto Costituzionale Tributario. Padova: CEDAM, 1959

VILANOVA, Lourival. Estruturas lógicas e o sistema de direito positivo. $3^{\mathrm{a}}$ ed. São Paulo: Noeses, 2005.

___ Causalidade e relação no direito. São Paulo: Saraiva, 1989.

VITTA, Heraldo Garcia. A sanção no direito administrativo. São Paulo: Malheiros, 2003.

____ Poder de polícia. São Paulo: Malheiros, 2010.

WALD, Arnoldo. O direito da regulação monetária e bancária. Revista de Direito Bancário, do mercado de capitais e da arbitragem, n. 17, São Paulo, julhosetembro 2002, p. 20-28.

WELZEL, Hans. O novo sistema jurídico-penal: uma introdução à doutrina da ação finalista. São Paulo: RT, 2001.

WOLF, Hans Julius; BACHOF, Otto; STOBER, Rolf. Direito administrativo. Tradução de António Francisco de Sousa. Lisboa: Fundação Calouste Gulbenkian, 2006.

ZELLER, Ernst. Auslegung von Gesetz und Vertrag, Methodenlehre für die juristische Praxis. Zurique: Schulthess Polygraphischer, 1989.

ZIPPELIUS, Reinhold. Juristische Methodenlehre, eine Einführung. $6^{\mathrm{a}}$ ed. Munique: C. H. Beck'sche, 1994. 